\title{
Development of a Chemistry-Based, Predictive Method for Determining the Amount of Non-Pertechnetate Technetium in the Hanford Tanks: FY2012 Progress Report
}

$\begin{array}{ll}\text { BM Rapko } & \text { TG Levitskaia } \\ \text { SA Bryan } & \text { JM Peterson } \\ \text { JL Bryant } & \text { RA Peterson } \\ \text { S Chatterjee } & \text { SI Sinkov } \\ \text { MK Edwards } & \text { FN Smith } \\ \text { JY Houchin } & \text { R Wittman } \\ \text { T Janik } & \end{array}$

January 2013

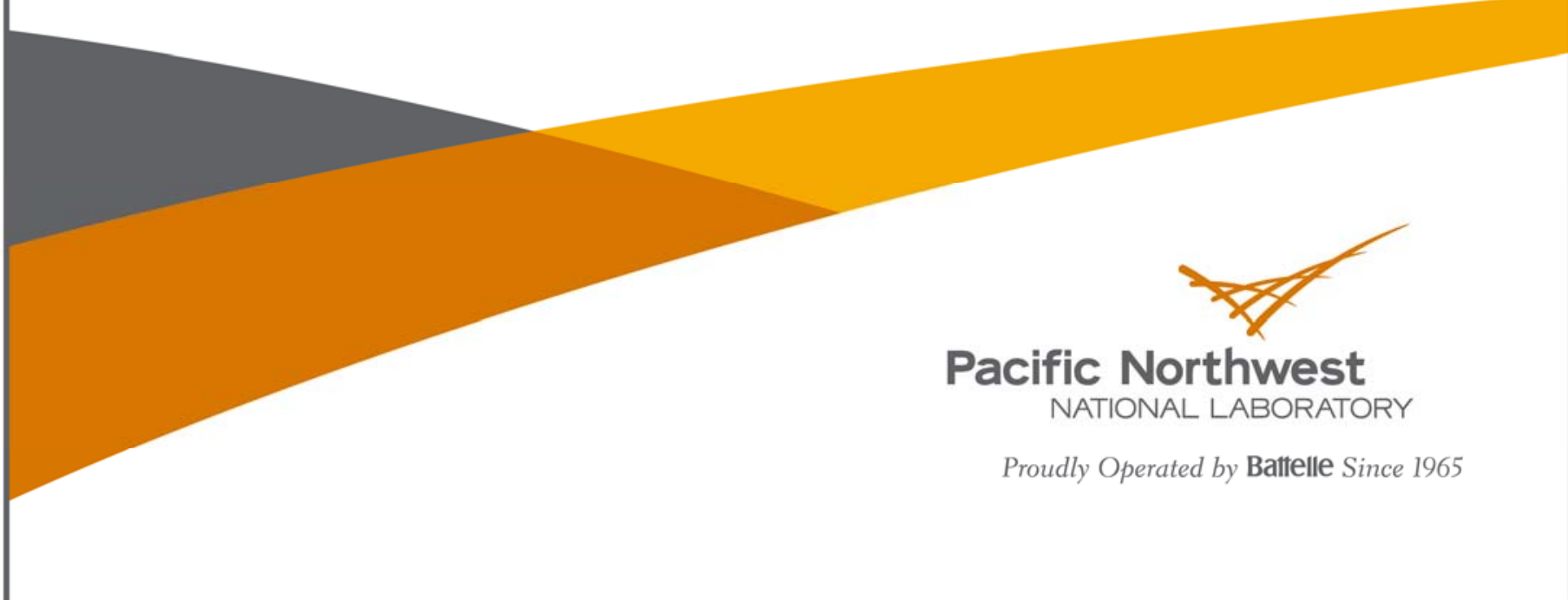




\title{
DISCLAIMER
}

This report was prepared as an account of work sponsored by an agency of the United States Government. Neither the United States Government nor any agency thereof, nor Battelle Memorial Institute, nor any of their employees, makes any warranty, express or implied, or assumes any legal liability or responsibility for the accuracy, completeness, or usefulness of any information, apparatus, product, or process disclosed, or represents that its use would not infringe privately owned rights. Reference herein to any specific commercial product, process, or service by trade name, trademark, manufacturer, or otherwise does not necessarily constitute or imply its endorsement, recommendation, or favoring by the United States Government or any agency thereof, or Battelle Memorial Institute. The views and opinions of authors expressed herein do not necessarily state or reflect those of the United States Government or any agency thereof.

\author{
PACIFIC NORTHWEST NATIONAL LABORATORY \\ operated by \\ BATTELLE \\ for the \\ UNITED STATES DEPARTMENT OF ENERGY \\ under Contract DE-AC05-76RL01830 \\ Printed in the United States of America \\ Available to DOE and DOE contractors from the \\ Office of Scientific and Technical Information, \\ P.O. Box 62, Oak Ridge, TN 37831-0062; \\ ph: (865) 576-8401 \\ fax: $(865) 576-5728$ \\ email: reports@adonis.osti.gov
}

Available to the public from the National Technical Information Service

5301 Shawnee Rd., Alexandria, VA 22312

ph: (800) 553-NTIS (6847)

email: orders@ntis.gov $<$ http://www.ntis.gov/about/form.aspx >

Online ordering: http://www.ntis.gov

This document was printed on recycled paper. 


\title{
Development of a Chemistry-Based, Predictive Method for Determining the Amount of Non-Pertechnetate Technetium in the Hanford Tanks: FY 2012 Progress Report
}

\author{
BM Rapko \\ TG Levitskaia \\ SA Bryan \\ JM Peterson \\ JL Bryant \\ RA Peterson \\ S Chatterjee \\ SI Sinkov \\ MK Edwards \\ FN Smith \\ JY Houchin \\ R Wittman
}

T Janik

January 2013

Prepared for

the U.S. Department of Energy

under Contract DE-AC05-76RL01830

Pacific Northwest National Laboratory

Richland, Washington 99352 



\section{Executive Summary}

This report describes investigations directed toward understanding the extent of the presence of highly alkaline soluble, non-pertechnetate technetium (n-Tc) in the Hanford Tank supernatants. The goals of this report are to: a) present a review of the available literature relevant to the speciation of technetium in the Hanford tank supernatants, b) attempt to establish a chemically logical correlation between available Hanford tank measurements and the presence of supernatant soluble $n-T c, c)$ use existing measurement data to estimate the amount of n-Tc in the Hanford tank supernatants, and d) report on any likely, processfriendly methods to eventually sequester soluble n-Tc from Hanford tank supernatants.

The work described herein follows on a substantial literature developed in the 1990s and early 2000 s that first identified the problem of the presence of $n-T c$ and led to a tentative identification of the species in at least two Hanford tank waste supernatants. This project attempted to correlate chemically relevant indicators for which quality-valid data exists in the TWINS database suitable for eventual extrapolation to as-yet untested tank supernatants. In addition, two other tangential tasks were undertaken. First, a model was developed that expanded upon a previously published model by Lukens et al. (2001), for the rate of reduction of pertechnetate by radiolysis and inorganic chemical-based processes. Using information obtained from TWINS, this model was applied to the Hanford tank supernatants to identify the rate of pertechnetate reduction in the various Hanford tank supernatants. Second, one proposed species for n-Tc, the complex $\left[(\mathrm{CO})_{3} \mathrm{Tc}\left(\mathrm{H}_{2} \mathrm{O}\right)_{3}\right]^{+}$, was prepared, and initial studies into its spectroscopic signature and chemical stability were performed.

From this work, the only acceptable chemically based correlations with data from the TWINS database were that the fraction of n-Tc present negatively correlates with either of two, closely related variables: total dose experienced in the tank, and ${ }^{137} \mathrm{Cs}$ concentration in the tank supernatants. The observed inverse correlation is counterintuitive, but a possible explanation is discussed. However, the correlation should lend some insight as to which tanks might be tested to further validate and enhance the predictive value of this correlation.

As noted above, chemical data, radiolysis constants and known chemical rate constants for the reaction of water radiolysis products with inorganic Hanford tank waste supernatant constituents were used to evaluate the relative rates of pertechnetate reduction in the Hanford tank supernatants. These results are summarized in the report. Interestingly, the reduction rate for pertechnetate is greatest in two tanks, AZ101 and AZ-102, where the presence of $\mathrm{n}-\mathrm{Tc}$ is not detected. However, this reduction only concerns the rate of pertechnetate reduction; the speciation of the reduced product is not addressed. Consequently, reduction of pertechnetate to the poorly alkaline-soluble technetium dioxide could occur and would not be detected as the $n-T c$ species of interest here. Still, based on the developed model, the majority of pertechnetate should have been removed through pertechnetate reduction. The actual observation that a large fraction of the technetium is present as pertechnetate calls attention to the importance of reoxidation of these reduced species, which is needed to account for the actual observations.

Finally, the preparation, characterization, and initial alkaline solution stability tests on $\left[(\mathrm{CO})_{3} \mathrm{Tc}\left(\mathrm{H}_{2} \mathrm{O}\right)_{3}\right]^{+}$ were performed. Previous literature indicates that in $1 \mathrm{M} \mathrm{NaOH}$ and in the absence of complexants, $\left[(\mathrm{CO})_{3} \mathrm{Tc}\left(\mathrm{H}_{2} \mathrm{O}\right)_{3}\right]^{+}$reoxidizes to pertechnetate in air over the course of a week. Similar behavior was observed under less alkaline conditions ( $\mathrm{pH}$ approximately 12 ). In spite of this small window, we were able to prepare the compound and obtain its UV-vis spectroscopic spectrum, hitherto unreported. Other 
spectroscopic methods, such as infrared and Raman spectroscopy proved unsuitable at the micromolar technetium concentrations examined to date.

The investigations described in this report are divided into several sections. The first section provides a brief introduction to previous studies in the area; the second section describes efforts to correlate various chemical and physical tank data available through TWINS, with the previously measured fractions of nTc measured in a limited number of Hanford tank supernatants. The third section describes our attempts to use measured chemical and radiolysis rate constants to predict the rates at which pertechnetate would be reduced. We hoped this correlation might suggest candidate tank supernatants with previously unrecognized amounts of $\mathrm{n}$-Tc for testing. The fourth section reports on initial experiments concerning the preparation, characterization, and alkaline stability of a prototypical n-Tc candidate, $\left[(\mathrm{CO})_{3} \mathrm{Tc}\left(\mathrm{H}_{2} \mathrm{O}\right)_{3}\right]^{+}$. Finally, the conclusion summarizes the results and proposes a speculative hypothesis to account for the observed technetium tank chemistry. The appendices provided summarize the available tank variable to the percentage of non-pertechnetate, as well as a summary of the rate equations and rate constants used in the pertechnetate reduction model. 


\section{Acknowledgments}

The authors would like to thank Tom Fletcher at DOE's Office of River Protection for support of this work. We would also like to thank Rebecca Robbins of Washington River Protection Solutions for helpful discussions and Gregg Lumetta of PNNL for his technical review. Finally, we would like to thank Janice Haigh and Lisa Staudinger for their editorial assistance in preparing this manuscript and Shirley Brooks for her data review. 



\section{Acronyms and Abbreviations}

$\begin{array}{ll}\text { EXAFS } & \text { Extended X-ray absorption fine structure } \\ \text { HEDTA } & \text { N-(2-hydroxyethyl)ethylenediaminetriacetic acid) } \\ \text { IDA } & \text { Iminodiacetic acid } \\ \text { NTA } & \text { Nitrilotriacetic acid } \\ \text { n-Tc } & \text { Non-pertechnetate technetium } \\ \text { TIC } & \text { Total inorganic carbon } \\ \text { TOC } & \text { Total organic carbon } \\ \text { TWINS } & \text { Tank Waste Information Network System } \\ \text { UV-vis } & \text { Ultraviolet-visible } \\ \text { XANES } & \text { X-ray Absorption Near Edge Structure }\end{array}$




\section{Contents}

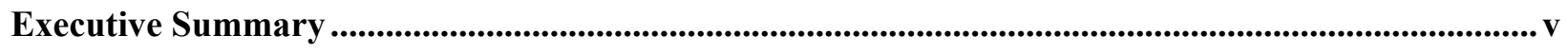

Acknowledgments ................................................................................................................................................

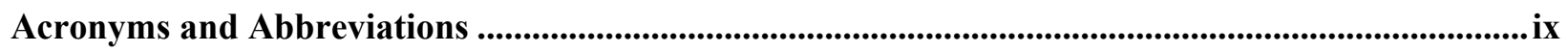

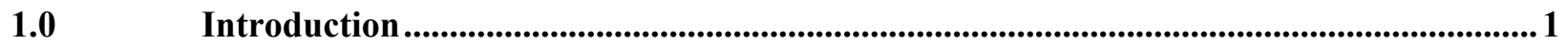

2.0 Development of a Chemistry-Based, Predictive Method ......................................................8

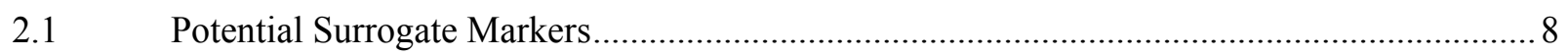

2.2 TWINS Data Correlations with Percent n-Tc in Hanford Tank Wastes ............................. 9

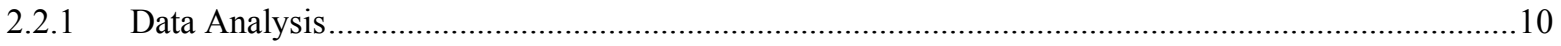

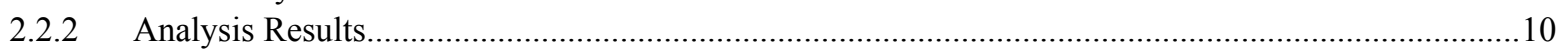

3.0 Calculation of Rates Based on Aqueous Radiolysis .................................................... 13

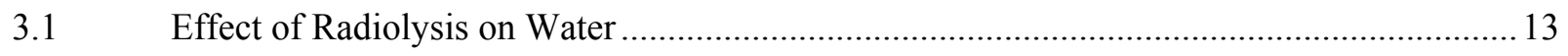

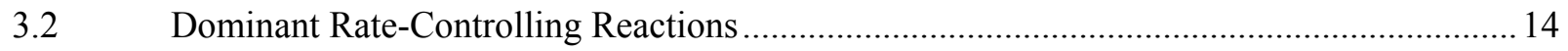

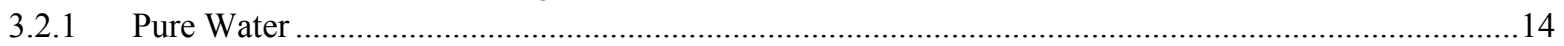

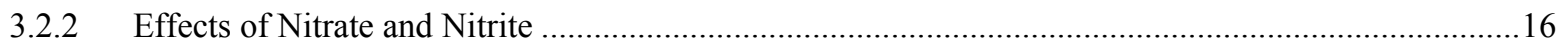

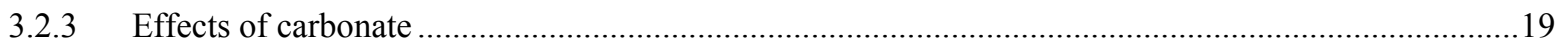

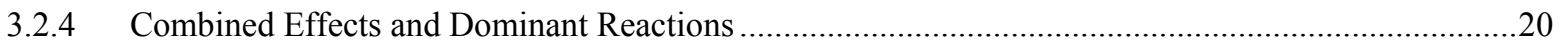

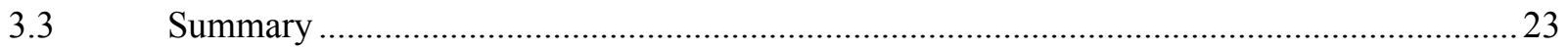

4.0 Preparation, Characterization, and Initial Stability Evaluation of $\left[(\mathrm{CO})_{3} \mathrm{Tc}\left(\mathrm{H}_{2} \mathrm{O}\right)_{3}\right]^{+} . .25$

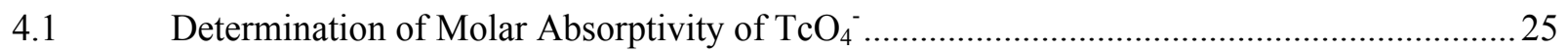

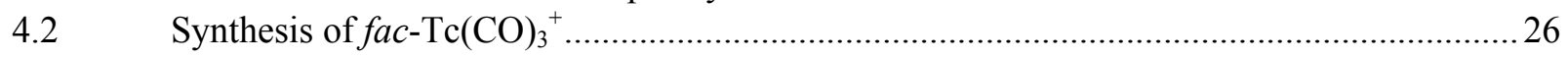

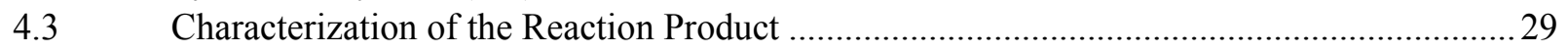

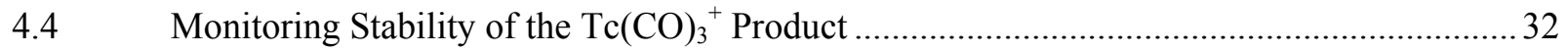

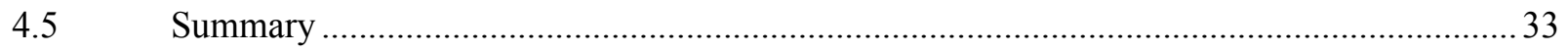

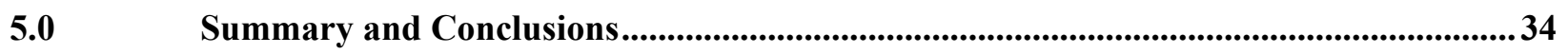

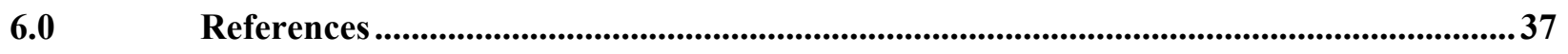

Appendix A : Plots of TWINS data versus \% n-Te for Hanford Tank Wastes .................................. A.1

Appendix B : Table of calculated rates of pertechnetate reduction in Hanford tanks based on the model described in Section 3.0 ....................................................................................... B.

Appendix C : Calculated Rates of Pertechnetate Reduction in Hanford Tanks ............................... C.1 


\section{Figures}

Figure 1: E-pH diagram for technetium (Schweitzer and Pesterfield 2010).................................

Figure 2: Technetium K-edge XANES spectra (Lukens et al. 2004) .........................................6

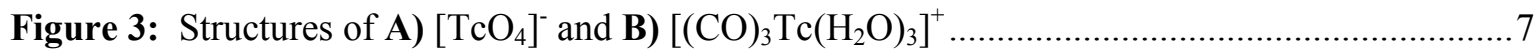

Figure 4: Percent n-Tc in Hanford tank supernatants versus measured sodium concentrations ......11

Figure 5: Plot of percent $n-T c$ versus total soluble technetium ...............................................11

Figure 6: Plot of percent $n-\mathrm{Tc}$ versus solution concentration of ${ }^{137} \mathrm{Cs}$........................................ 12

Figure 7: Plot illustrating rate of $\mathrm{TcO}_{4}{ }^{-}$reduction in neutral water as a function of dose.............. 16

Figure 8: Effect of nitrate on $\mathrm{TcO}_{4}{ }^{-}$reduction rates as a function of dose for a neutral water scenario

Figure 9: Effect of nitrate $\left[\mathrm{NO}_{3}{ }^{-}\right]$and $\left[\mathrm{OH}^{-}\right]$on $\mathrm{TcO}_{4}{ }^{-}$reduction rates as a function of dose for a

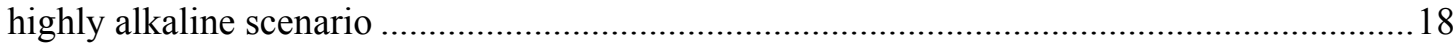

Figure 10: Effect of carbonate $\left(\left[\mathrm{CO}_{3}{ }^{2-}\right]=1 \mathrm{M}\right)$ on $\mathrm{TcO}_{4}{ }^{-}$reduction rates in presence of $2.4 \mathrm{M}$ $\left[\mathrm{NO}_{3}{ }^{-}\right]$and $2 \mathrm{M}\left[\mathrm{OH}^{-}\right]$

Figure 11: Effect of nitrite $\left(\left[\mathrm{NO}_{2}{ }^{-}\right]=1.5 \mathrm{M}\right)$ on $\mathrm{TcO}_{4}{ }^{-}$reduction rates in the presence of $1 \mathrm{M}$ $\left[\mathrm{CO}_{3}{ }^{2-}\right], 2.4 \mathrm{M}\left[\mathrm{NO}_{3}^{-}\right]$, and $2 \mathrm{M}\left[\mathrm{OH}^{-}\right]$

Figure 12: Effect of low $[\mathrm{OH}-](0.01 \mathrm{M})$ on $\mathrm{TcO}_{4}{ }^{-}$reduction rates in the presence of $1 \mathrm{M}^{2} \mathrm{CO}_{3}{ }^{2-}$ ], 2.4 $\mathrm{M}\left[\mathrm{NO}_{3}^{-}\right]$, and $\left.1.5 \mathrm{M}^{-} \mathrm{NO}_{2}^{-}\right]$ 23

Figure 13: Plot showing $\mathrm{Tc}(\mathrm{VII}) \mathrm{O}_{4}{ }^{-}$concentration in solution as a function of dose (high, solid; low, dashed) and inorganic species of interest

Figure 14: UV absorbance spectral layout and corresponding Beer's plots (left and right respectively)

Figure 15: Experimental apparatus used for synthesis of $\mathrm{Tc}(\mathrm{CO})_{3}{ }^{+}$via reduction of $\mathrm{TcO}_{4}{ }^{-}$

Figure 16: Comparison of aqueous $\mathrm{KTcO}_{4}$ solution UV spectra in the carbonate buffer (red trace) and in $\mathrm{Na}_{2} \mathrm{CO}_{3} / \mathrm{NaBH}_{4}$ mixture (green trace) prior to reaction start ...............................28

Figure 17: Monitoring of the $\mathrm{TcO}_{4}{ }^{-}$reduction by the UV spectroscopy

Figure 18: Comparison of UV spectra of reaction mixture. Samples collected on 10/05/2012 right after reaction completion (red), 10/08/2012 subjected to treatment (blue), and 10/08/2012 after Purolite A850 purification (yellow). 30

Figure 19: UV Spectra of reaction mixture.

Figure 20: Time-dependent UV spectra of unmodified reaction mixture (left) and the reaction subjected to acid/base wwing with (center) and without (right) ion exchange pretreatment....33

Figure 21: Minimalist schematic of Hanford tank technetium chemistry .34

Figure A - 1: Total organic carbon (TOC), including all tanks of interest (data in $\mu \mathrm{g} / \mathrm{mL}$ ). A.6 
Figure A - 2: TOC, without tanks AN-102 and AN-107 (in $\mu \mathrm{g} / \mathrm{mL})$

Figure A - 3: Total inorganic carbon (TIC), with and without tanks AN-102 and AN-107 (in $\mu \mathrm{g} / \mathrm{mL})$

Figure A - 4: Nitrite with and without tanks AN-102 and AN-107 (in $\mu \mathrm{g} / \mathrm{mL})$

Figure A - 5: Hydroxide with and without tanks AN-102 and AN-107 (in $\mu \mathrm{g} / \mathrm{mL}$ ).

Figure A - 6: Sodium with and without Tanks AN-102 and AN-107 (in $\mu \mathrm{g} / \mathrm{mL}$ ).

Figure A - 7: Technetium-99 in supernatant (in $\mu \mathrm{g} / \mathrm{mL}$ )

Figure A - 8: Technetium-99 in supernatant $(\mu \mathrm{Ci} / \mathrm{mL})$.

Figure A - 9: Soluble transuranics $-{ }^{241} \mathrm{Am}(\mu \mathrm{Ci} / \mathrm{mL})$

Figure A - 10: Soluble transuranics - plutonium, with tanks AN-102 and AN-107 ( $\mu \mathrm{Ci} / \mathrm{mL})$.A.15

Figure A - 11: Soluble transuranics - plutonium (in $\mu \mathrm{Ci} / \mathrm{mL}$ ) without tanks AN-102 and AN-107A.16

Figure A - 12: Soluble transuranics - plutonium $(\mu \mathrm{g} / \mathrm{mL})$ without tanks AN-102 and AN-107 A.17

Figure A - 13: Soluble transuranics - strontium $(\mu \mathrm{Ci} / \mathrm{mL})$ with tanks $\mathrm{AN}-102$ and $\mathrm{AN}-107$....A.18

Figure A - 14: Soluble transuranics - strontium (in $\mu \mathrm{Ci} / \mathrm{mL}$ ) without tanks AN-102 and AN-107A.19

Figure A - 15: Soluble transuranics - strontium $(\mu \mathrm{g} / \mathrm{mL})$ with and without tanks AN-102 and $\mathrm{AN}-107$

Figure A - 16: Technetium-99 - solids phase without tank AN-107, but with tank AN-102 $(\mu \mathrm{Ci} / \mathrm{g})$

Figure A - 17: Techetium-99 - solids phase $(\mu \mathrm{Ci} / \mathrm{g})$ without tanks $\mathrm{AN}-102$ and $\mathrm{AN}-107 \ldots \ldots . . . \mathrm{A} .22$

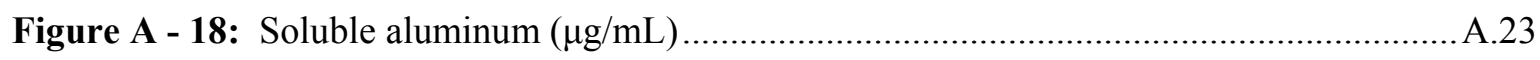

Figure A - 19: Noble metals in solid phase - palladium $(\mu \mathrm{g} / \mathrm{g})$........................................... A.24

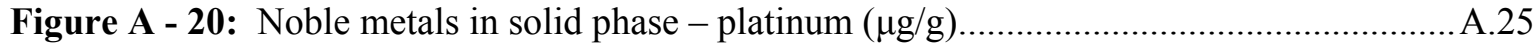

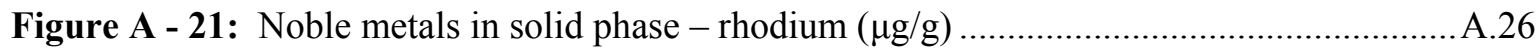

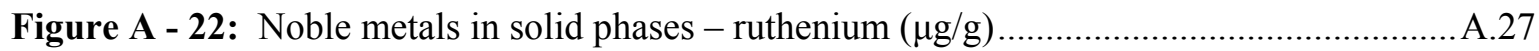

Figure A - 23: Noble metals in solid phases - ruthenium/rhodium-106 (Data in $\mu \mathrm{Ci} / \mathrm{g}$ ) ........... A.28

Figure A - 24: Unit liter dose (ULD) - all tanks of interest (in Sv/L) ......................................29

Figure A - 25: ULD without tanks AN-102 and AN-107 (in Sv/L) .......................................30

Figure A - 26: ULD, “offsite"- all tanks of interest (in Sv/L) ..................................................

Figure A - 27: ULD, "offiste” without tanks AN-102 and AN-107 (Sv/L) ................................32

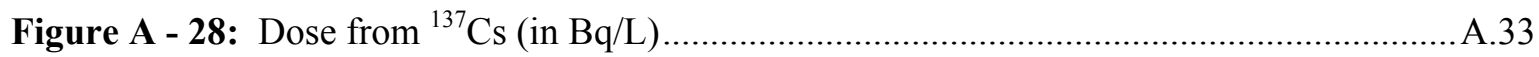

Figure A - 29: Dose from ${ }^{137} \mathrm{Cs}(\mathrm{Bq} / \mathrm{L})$ without tank AZ-101 ….......................................... A.34

Figure A - 30: Dose from ${ }^{137} \mathrm{Cs}($ in $\mathrm{Bq} / \mathrm{L})$ without tanks $\mathrm{AN}-102$ and $\mathrm{AN}-107$....................... A.35

Figure A - 31: Dose from ${ }^{137} \mathrm{Cs}($ in $\mathrm{Bq} / \mathrm{L})$ without tanks $\mathrm{AN}-102, \mathrm{AN}-107$, and $\mathrm{AZ}-101 \ldots \ldots \ldots . \mathrm{A} .36$ 
Figure A - 32: Dose from ${ }^{89 / 90} \mathrm{Sr}$, all tanks of interest (in $\left.\mu \mathrm{Ci} / \mathrm{mL}\right)$...................................... A.37

Figure A - 33: Dose from ${ }^{89 / 90} \mathrm{Sr}$ without tanks AN-102 and AN-107 ( $\left.\mu \mathrm{Ci} / \mathrm{mL}\right)$....................... A.38

Figure A - 34: Dose from ${ }^{90} \mathrm{Sr}$, all tanks of interest (in Bq/L) ............................................. A.39

Figure A - 35: Dose from ${ }^{90} \mathrm{Sr}$ without tanks $\mathrm{AN}-102$ and $\mathrm{AN}-107$ (in $\left.\mathrm{Bq} / \mathrm{L}\right)$.........................A.40

Figure A - 36: Nitrate (all tanks; data in $\mu \mathrm{g} / \mathrm{mL}$ ) ............................................................... A.41

Figure A - 37: Nitrate without tanks AN-102 and AN-107 (in $\mu \mathrm{g} / \mathrm{mL})$.................................. A.42 


\section{Tables}

Table 1: Reported Distribution of Non-pertechnetate Technetium Present in Various Hanford

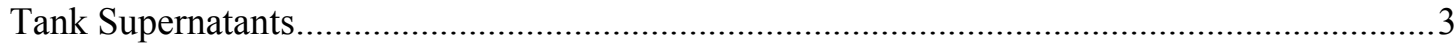

Table 2: Possible Radiolytic Reductants and Oxidants (Mincher and Mezyk 2009)..................... 13

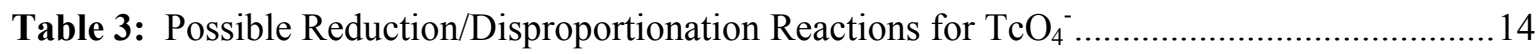

Table A - 1: Summary of Values shown in Appendix A Plots of \% n-Te versus Various Hanford

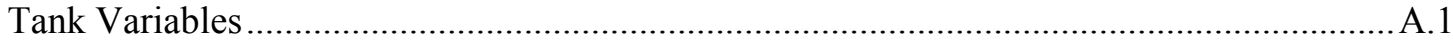

Table B - 1: Summary of the Rates of Pertechnetate Reduction as Calculated by the Equations

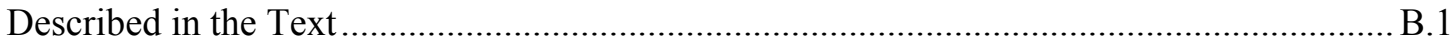




\subsection{Introduction}

This report describes investigations directed toward understanding the extent of the presence of highly alkaline soluble, non-pertechnetate technetium (n-Tc) in the Hanford Tank supernatants. The goals of this report are to: a) present a review of all the available literature relevant to the speciation of technetium in the Hanford tank supernatants, b) attempt to establish a chemically logical correlation between available Hanford tank measurements and the presence of supernatant soluble non-pertechnetate technetium (n-Tc), c) use existing measurement data to estimate the amount of n-Tc in the Hanford tank supernatants, and d) report on any likely, process-friendly methods to eventually sequester soluble n-Tc from Hanford tank supernatants.

In the 1990s, removal of technetium in the form of pertechnetate was part of the flowsheet for remediation of the waste in the Hanford Area storage tanks. Based on E-pH diagrams, in aerated alkaline solutions (see Figure 1), the predominant soluble species was assumed to be technetium in the formally +7 oxidation state, specifically as pertechnetate $\left[\mathrm{TcO}_{4}\right]^{-}$. An issue first surfaced when materials and processes were being tested for their efficacy at pertechnetate removal (Schroeder et al. 1995; Blanchard Jr. et al. 1996; Blanchard Jr. et al. 1997; Schroeder et al. 1998; Kurath et al. 2000; Blanchard Jr. et al. 2000a; Blanchard Jr. et al. 2000b; Hassan et al. 2000a; Hassan et al. 2000b; King et al. 2001; Burgeson et al. 2002; Hassan et al. 2003; Burgeson et al. 2004b; Burgeson et al. 2004a; Egorov et al. 2004; Burgeson et al. 2005; Egorov et al. 2012). 


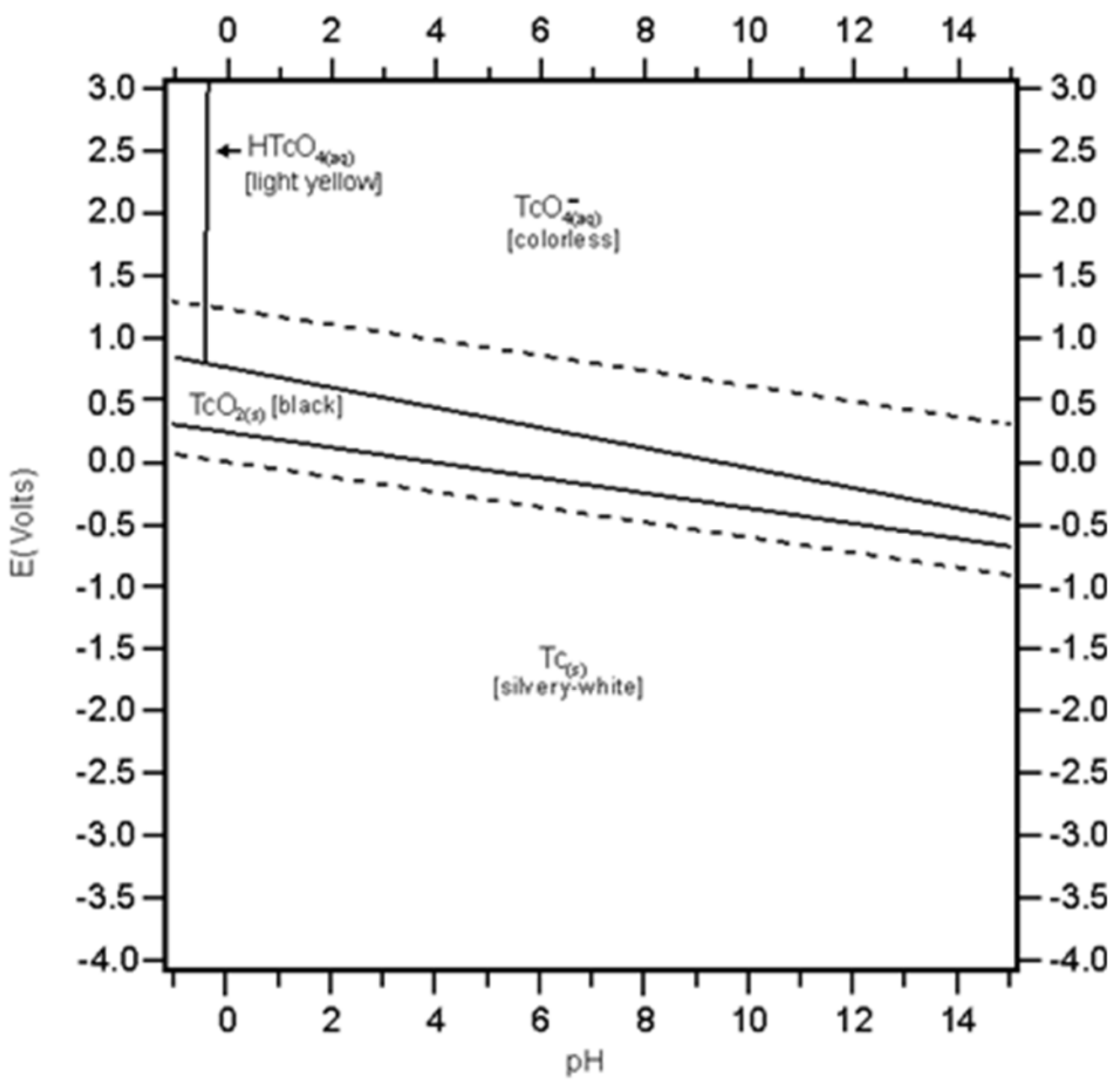

\section{Equations for these lines:}

$$
\begin{array}{ll}
\mathrm{HTCO}_{4} / \mathrm{TCO}_{2} & E=0.80-0.059 \mathrm{pH}+0.020 \log \left[\mathrm{H} \mathrm{TCO}_{4}\right] \\
\mathrm{TCO}_{4} / \mathrm{TCO}_{2} & E=0.79-0.079 \mathrm{pH}+0.020 \log \left[\mathrm{TCO}_{4}{ }^{-}\right] \\
\mathrm{TCO}_{2} / \mathrm{TC} & E=0.25-0.059 \mathrm{pH} \\
\mathrm{TCO}_{4}-\mathrm{HTCO}_{4} & \mathrm{pH}=-0.4
\end{array}
$$

Figure 1: E-pH diagram for technetium (Schweitzer and Pesterfield 2010)

For several of the tank supernatants, tanks that represent various waste types, the amount of technetium removed was only a variable fraction of the total soluble technetium present - and in some cases it was demonstrated that the alkaline soluble technetium could be removed very effectively, but in several cases it was not. Not only was this behavior observed with several tank supernatant samples, it was found during testing performed at various laboratories and often using different means of technetium analysis. Furthermore, some testing was done where technetium, added as ${ }^{95 \mathrm{~m}} \mathrm{Tc}$ in the form of pertechnetate, was compared to the ${ }^{99} \mathrm{Tc}$ present in the Hanford tank waste supernatants and differing behaviors were observed. Specifically, the portion of pertechnetate, as indicated by the behavior of the added ${ }^{95 \mathrm{~m}} \mathrm{Tc}$, would often be sequestered more effectively than the ${ }^{99} \mathrm{Tc}$ present in the tank waste (Schroeder et al. 1995; Blanchard Jr. et al. 1996; Blanchard Jr. et al. 2000b; Schroeder et al. 2001). From these tests and other information, it was generally concluded that some of the technetium in the Hanford tank wastes was 
not present in the form of pertechnetate. Furthermore, the magnitude of $n$-Tc fraction differed considerably from tank waste to tank waste; but in general, good agreement between laboratories was found for the same source of tank waste as summarized in Table 1.

Table 1: Reported Distribution of Non-pertechnetate Technetium Present in Various Hanford Tank Supernatants

\begin{tabular}{|c|c|c|c|c|}
\hline Tank & Method & $\begin{array}{c}\% \text { Non- } \\
\text { pertechnetate } \\
\text { (Max) }\end{array}$ & $\begin{array}{c}\% \text { Non- } \\
\text { pertechnetate } \\
\text { (Min) }\end{array}$ & Source \\
\hline AN-102 & SL-639 lag breakthrough & 70 & 60 & (King et al. 2001) \\
\hline AN-102 & SL-639 column & 80 & 70 & (Hassan et al. 2000b) \\
\hline AN-102 & SL-639 column & 70 & & (King et al. 2000) \\
\hline AN-102 & Multiple SL-639 contacts & 63 & & (Hassan et al. 2001b) \\
\hline AN-102 & $\begin{array}{l}\text { MP-1 captured TcO4- } \\
\text { before/after oxidation }\end{array}$ & 57 & & (Egorov et al. 2004) \\
\hline AN-102 & SL-639 column & 48 & & (Egorov et al. 2012) \\
\hline AN-103 & SL-639 lag breakthrough & 8 & 7 & (King et al. 2001) \\
\hline AN-103 & SL-639 column & 8 & 3 & (McCabe et al. 2000) \\
\hline AN-103 & SL-639 column & 2.4 & 2.4 & (Hassan et al. 2000a) \\
\hline AN-103 & Multiple SL-639 contacts & 1.6 & & (Hassan et al. 2001b) \\
\hline AN-107 & XANES fit & 62 & & (Blanchard Jr. et al. 1997) \\
\hline AN-107 & SL-639 batch contacts & 78 & 75 & (Kurath et al. 2000) \\
\hline AN-107 & SL-639 column & 80 & & (Blanchard Jr. et al. 2000b) \\
\hline AN-107 & Fit to Kd Reilley HPQ & 63 & 48 & (Schroeder et al. 1998) \\
\hline AN-107 & Fit to Kd Reilley HPQ & 67 & & (Schroeder and Ashley 2005) \\
\hline AN-107 & $\begin{array}{l}\text { MP-1 captured TcO4- } \\
\text { before/after oxidation }\end{array}$ & 57 & & (Egorov et al. 2004) \\
\hline AN-107 & SL-639 column & 50 & & (Egorov et al. 2012) \\
\hline
\end{tabular}




\begin{tabular}{|c|c|c|c|c|}
\hline Tank & Method & $\begin{array}{l}\text { \% Non- } \\
\text { pertechnetate } \\
\text { (Max) }\end{array}$ & $\begin{array}{c}\% \text { Non- } \\
\text { pertechnetate } \\
\text { (Min) }\end{array}$ & Source \\
\hline AP-104 & $\begin{array}{l}\text { MP-1 captured TcO4- } \\
\text { before/after oxidation }\end{array}$ & 72 & & (Egorov et al. 2004) \\
\hline AP-104 & SL-639 column & 72 & & (Egorov et al. 2012) \\
\hline AW-101 & SL-639 column & 0.06 & 0 & (Hassan et al. 2003) \\
\hline AW-101 & Reillex HPQ column & 15 & & (Blanchard Jr. et al. 1996) \\
\hline AW-101 & SL-639 batch contacts & 2.9 & & (Kurath et al. 2000) \\
\hline AW-101 & $\%$ Tc in feed vs effluent & 4.5 & & (Hassan et al. 2003) \\
\hline$A Z-101$ & SL-639 column & 0 & 0 & (Egorov et al. 2012) \\
\hline AZ-102 & SL-639 column & 0 & 0 & (Egorov et al. 2012) \\
\hline$A Z-102$ & Feed and Product Tc ratio & 33 & & (Hassan et al. 2003) \\
\hline AZ-102 & SL-639 column & 0.04 & 0 & (Hassan et al. 2001a) \\
\hline AZ-102 & Multiple SL-639 contacts & $<0.1$ & & (Hassan et al. 2001b) \\
\hline DSSF & Reillex HPQ batch Kd & 7 & & (Blanchard Jr. et al. 1997) \\
\hline SY-101 & Reillex HPQ batch Kd & 53 & & (Blanchard Jr. et al. 1997) \\
\hline SY-101 & Fit to Kd Reilley HPQ & 70 & & $\begin{array}{l}\text { (Schroeder et al. 1998; } \\
\text { Schroeder et al. 1995) }\end{array}$ \\
\hline SY-101 & $\begin{array}{c}\text { Fit to Kd Reilley HPQ/TcO4 } \\
\text { by NMR }\end{array}$ & 70 & 63 & (Schroeder et al. 2001) \\
\hline SY-103 & Reillex HPQ batch Kd & 54 & & (Blanchard Jr. et al. 1997) \\
\hline SY-103 & XANES fit & 78 & & (Blanchard Jr. et al. 1997) \\
\hline SY-103 & Fit to Kd Reilley HPQ & 64 & & $\begin{array}{l}\text { (Schroeder et al. 1998; } \\
\text { Schroeder et al. 1995) }\end{array}$ \\
\hline SY-103 & $\begin{array}{c}\text { Fit to Kd Reilley } \mathrm{HPO} / \mathrm{TcO} 4 \\
\text { by NMR }\end{array}$ & 70 & 64 & (Schroeder et al. 2001) \\
\hline
\end{tabular}


Technetium X-ray Absorption Near Edge Structure (XANES) spectroscopy confirmed this conclusion regarding the presence of $n-T c$ in two Hanford tank supernatants and indicated that the $n-T c$ is present as a lower oxidation state technetium compound (Blanchard Jr. et al. 1997). This conclusion was somewhat unexpected because, as noted above, in aerated alkaline solutions, the most stable form of technetium is generally that of pertechnetate $\left[\mathrm{TcO}_{4}\right]^{-}$, where technetium is present formally in the +7 oxidation state.

This new information stimulated several studies aimed at identifying the non-pertechnetate form of soluble technetium in Hanford tank wastes. The first category of lower-valence technetium compounds considered as candidates for the low-valence technetium in the Hanford tank supernatants were various compounds with technetium present formally in the +4 oxidation state.

One of the findings of these studies was that a variety of available methods can reduce pertechnetate to $\mathrm{Tc}(\mathrm{IV})$ in alkaline solutions. Any strong reductant can reduce pertechnetate. For example, products from the radiolysis of water, such as free electrons $\left(\mathrm{e}^{-}\right)$, deprotonated hydroxyl radicals $\left(\mathrm{O}^{-}\right)$, and reduced nitrate $\left(\mathrm{NO}_{3}{ }^{2-}\right)$ are all capable of reducing Tc(VII) in alkaline solution (Mincher and Mezyk 2009; Lukens et al. 2001; Berning et al. 2005; Sekine et al. 2002; Lukens et al. 2002).

Chemical methods to reduce pertechnetate also have been reported. It has been shown that in the presence of the noble metals (ruthenium, rhodium, and/or platinum), alkaline $\mathrm{pH}$, elevated temperatures, and organic molecules, catalytically active metals are formed that are capable of reducing pertechnetate (Bernard et al. 2001). The catalytically active metals in the presence of hydrogen only were also shown to be competent at pertechnetate reduction. It was shown subsequently that reducing sugars and polyaminocarboxylates themselves in alkaline solution are capable of reducing pertechnetate in the absence of significant solution radiolysis (Berning et al. 2005).

The fate of the reduced technetium in alkaline solution has also been investigated. In the absence of strong organic complexants, the product of Tc(VII) reduction in anaerobic, alkaline, aqueous solution is hydrous $\mathrm{Tc}(\mathrm{IV})$ dioxide, $\mathrm{TcO}_{2}-\mathrm{xH}_{2} \mathrm{O}$. The solubility of the hydrous $\mathrm{Tc}(\mathrm{IV})$ dioxide produced by alkaline pertechnetate reduction has been studied both in simple aqueous solutions and in the presence of various organic ligands (Boggs et al. 2010; Gu et al. 2011; Warwick et al. 2007; Xia et al. 2006). Based on this work, it appears unlikely that in the absence of strongly chelating organic ligands, soluble Tc(IV) compounds can account for the concentrations of n-Tc observed in several Hanford tanks.

It has also been observed that hydrous technetium dioxide readily will reoxidize to pertechnetate in alkaline solution upon exposure to oxygen (Gu et al. 2011; Lukens et al. 2006a). Extensive reoxidation of $\mathrm{Tc}(\mathrm{IV})$ to pertechnetate generally is observed in a matter of minutes to hours following exposure to oxygen (from air).

As alluded to above, Tc(IV) can be coordinated to a variety of organic molecules known to be present in Hanford tank supernatants, especially those with high concentrations of organic carbon. Specifically, in the presence of organic molecules that strongly complex metal ions, such as gluconate, available measurements indicate that their presence can lead to concentrations of soluble $\mathrm{n}$-Tc that approach the concentrations observed (roughly $1 \times 10^{-5} \mathrm{M}$ ) in Hanford tank supernatants (Hess et al. 2006; Lukens et al. 2006b). But again, like Tc(IV) dioxide itself, these Tc(IV) compounds were found to rapidly convert back to pertechnetate in alkaline solutions upon exposure to air. The non-pertechnetate compounds of technetium soluble in the Hanford tank supernatants have been shown to be stable for months. However, in the absence of Hanford tank sludge, slow oxidation of the soluble n-Tc to pertechnetate (half-lives of 
years) has been observed upon exposure to air (Schroeder et al. 2001). The rate of this conversion seems to be markedly dependent on the details of air exposure, although this aspect of non-pertechnetate chemistry remains relatively unexplored.

In conclusion, Tc(IV) compounds could be sufficiently soluble in alkaline solutions to account for a significant fraction, but likely not all, of the n-Tc in Hanford tank supernatants. However, such Tc(IV) compounds do not appear to be sufficiently stable with respect to aerobic reoxidation back to pertechnetate to be the $\mathrm{n}-\mathrm{Tc}$ species in the Hanford tank supernatants.

Such conclusions led to the investigation of alternative, low-valent, technetium compounds that possess the chemical and spectroscopic characteristics observed previously by Blanchard et al. Indeed, on the basis of some elegant technetium XANES studies (see Figure 2) by Lukens (2006b; 2004), strong evidence supports the identification of the form of $\mathrm{n}$-Tc for the two examples of Hanford tank waste supernatants studied to date, as that of a $\mathrm{Tc}(\mathrm{I})$ tricarbonyl compound, $\left[(\mathrm{CO})_{3} \mathrm{Tc}\left(\mathrm{H}_{2} \mathrm{O}\right)_{3}\right]^{+}$or, more likely, analogous compound(s) where the Tc-coordinated water molecules are replaced by other oxygen or nitrogen-atom binding functional groups such as hydroxide (under strongly basic conditions) or organic complexants such as gluconate or aminocarboxylates.

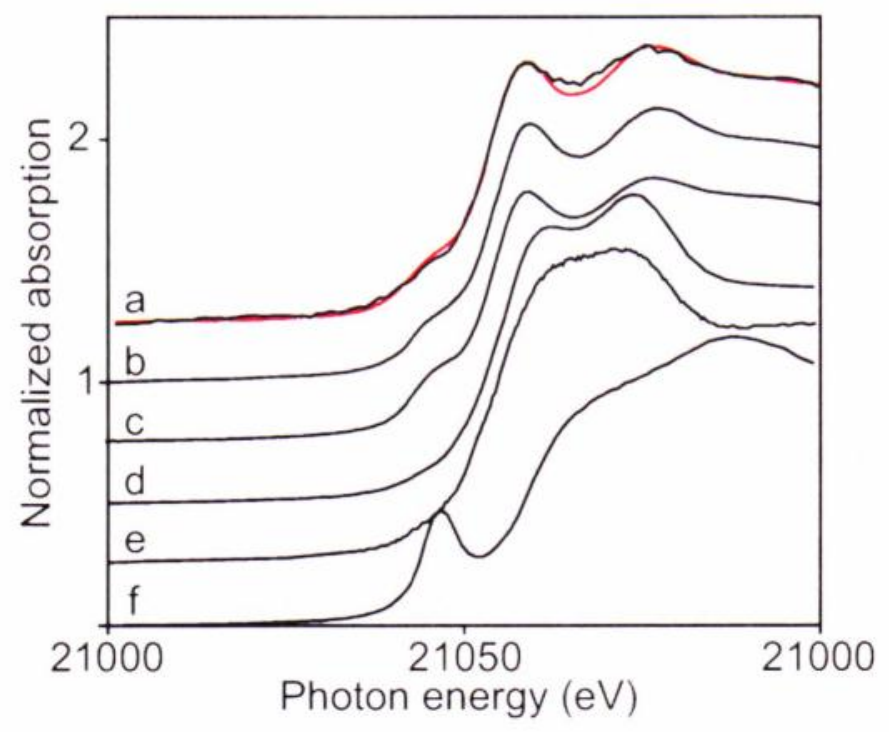

Figure 2: Technetium K-edge XANES spectra (Lukens et al. 2004) a) non-pertechnetate species in tank $S Y-103$ (black) and $T c(C O)_{3}(\text { gluconate) })^{2-}$ (red), b) $\mathrm{Tc}(\mathrm{CO})_{3}(\text { gluconate })^{2-}$, c) $\mathrm{Tc}(\mathrm{CO})_{3}(\mathrm{OH})\left(\mathrm{H}_{2} \mathrm{O}\right)_{2}$, d) $\mathrm{Tc}(\mathrm{IV})$ gluconate, e) $\mathrm{Tc}(\mathrm{IV})$ glyoxylate, f) $\mathrm{TcO}_{4}$.

Furthermore, recent research has shown that such substitutions for the water molecules in the $\mathrm{Tc}(\mathrm{I})$ tricarbonyl moiety can be a facile process (Lukens et al. 2006a; Seifert et al. 2000; Lukens et al. 2004; Alberto et al. 1998; Helm 2008). It is worth noting here that the possibility of replacing a carbonyl with a linear nitrosyl ligand to generate the neutral complex $\left[(\mathrm{NO})(\mathrm{CO})_{2} \mathrm{Tc}\left(\mathrm{H}_{2} \mathrm{O}\right)_{3}\right]$ or a similar derivative such as noted above is also a plausible candidate based on the available technetium XANES and EXAFS data. 
These candidate Tc(I) tri-carbonyl or dicarbonyl-nitrosyl compounds are well known in the radiopharmaceutical literature and appear to possess characteristics consistent with their presence in Hanford tank waste supernatants. First, when the three water molecules are replaced by organic complexants, the product (at least for $\left[\mathrm{Tc}(\mathrm{CO})_{3}(\text { gluconate })\right]^{2-}$ ) was reported to be stable in alkaline solutions for days without noticeable decomposition (Lukens et al. 2006; behavior at longer times has not been reported). Multiple groups have also reported that Tc(I)-tricarbonyl compounds can be readily synthesized in alkaline solutions by contact of carbon monoxide, $\mathrm{CO}$, with pertechnetate in the presence of a reductant at elevated (but plausible for Hanford waste) temperatures (Alberto et al. 1998).

In summary, although the specific details as to why n-Tc is present in varying extents in Hanford tank supernatants, spectroscopic measurements on the actual tank waste supernatants strongly suggest an octahedrally coordinated Tc(I) tricarbonyl compound (Figure 3) of some nature. This state of knowledge provides the starting point for the investigations described in this report.

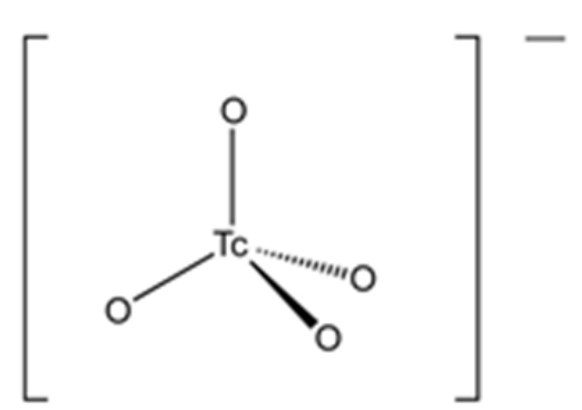

(A)

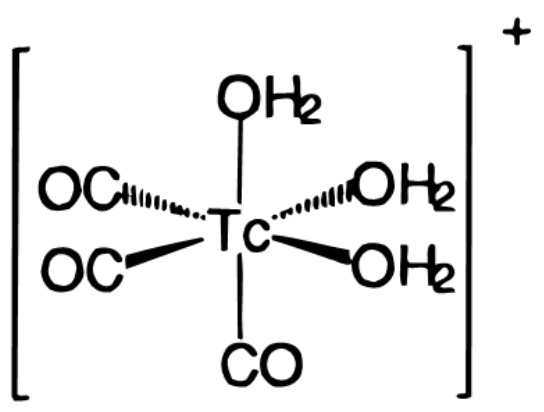

(B)

Figure 3: Structures of A) $\left[\mathrm{TcO}_{4}\right]^{-}$and $\left.\mathbf{B}\right)\left[(\mathrm{CO})_{3} \mathrm{Tc}\left(\mathrm{H}_{2} \mathrm{O}\right)_{3}\right]^{+}$ 


\subsection{Development of a Chemistry-Based, Predictive Method}

Based on the prior research summarized in the Introduction section above, it is assumed that the majority, if not all, of the n-Tc in all the Hanford tank supernatants is the Tc-tricarbonyl, pseudo-octahedrally coordinated species, $\left[(\mathrm{CO})_{3} \mathrm{Tc}\left(\mathrm{H}_{2} \mathrm{O}\right)_{3}\right]^{+}$, or some derivative thereof.

The next pertinent piece of information notes that there are three known methods to prepare this material; from $\left[\left(\mathrm{n}-\mathrm{Bu}_{4} \mathrm{~N}\right) \mathrm{TcOCl}_{4}\right]$ in the presence of $\mathrm{CO}$, borane/tetrahydrofuran and chloride to prepare

$\left[\mathrm{Cl}_{3} \mathrm{Tc}(\mathrm{CO})_{3}\right]^{2-}$, which, upon contact with water forms $\left[(\mathrm{CO})_{3} \mathrm{Tc}\left(\mathrm{H}_{2} \mathrm{O}\right)_{3}\right]^{+}$(Alberto et al. 1995); from $\left[\mathrm{CO}_{2^{-}}\right.$ $\left.\mathrm{BH}_{3}\right]^{2-}$ and pertechnetate in alkaline water in the presence of a weak complexant (Alberto et al. 2001); or from pertechnetate, $\mathrm{CO}$ and sodium borohydride in alkaline water in the presence of a weak complexant (Alberto et al. 1998). All of these methods can be broadly described as requiring contact of pertechnetate, carbon monoxide, and a reductant in aqueous, often alkaline solutions.

From this description, we can examine various tank waste characteristics that could conceivably correlate with those characteristics, obtain the relevant tank waste data based on actual tank waste data (note that this excludes the Best Basis Inventory as a source) and see if any correlations with previously measured, soluble non-pertechnetate/pertechnetate ratios exist. If such a strong, chemistry-based correlation is found, the relevant data for the entire tank farm can be culled and, from that an estimate of the total n-Tc in the Hanford tanks can be obtained.

\subsection{Potential Surrogate Markers}

Several potential surrogate markers for the fraction of soluble n-Tc in the Hanford tanks can be considered within this chemistry-based approach. These markers, together with a brief justification for their consideration, are summarized below.

1. Tank supernatant potentials. This measurement could serve as a broad substitute for the presence of any number of potential reductants for pertechnetate. However, insufficient tank data was found to correlate even to the relatively limited amount of n-Tc data that currently exists.

2. Total organic carbon. This method could serve as a proxy for a source of potential reductants and possibly a source of $\mathrm{CO}$ (which can be generated from the degradation of certain organic compounds).

3. Total inorganic carbon (carbonate). A potentially inversely correlated marker. The presence of air (more specifically the carbon dioxide in air) will react with the free hydroxide present in these alkaline tank solutions to form carbonate. The presence of aerated solution has two implications for the formation of non-pertechnetate compounds: first, the presence of oxygen can potentially reoxidize the non-pertechnetate species and second, the presence of circulating air can carry off any carbon monoxide present instead of leaving it available to form the Tc(I) carbonyl compound. As discussed below, data on the supernatant carbonate concentrations are too sparse for developing a complete correlation with the $\mathrm{n}$-Tc fraction present in the supernatant and total inorganic carbon includes not only carbonate but formate and oxalate in the measurements. However, the latter two compounds have no relevance to its potential use as an inversely correlated marker to the fraction of n-Tc and so, without knowing the fraction of the various compounds that go into making up the total inorganic carbon number, any observed correlation may be fortuitous. 
4. Nitrate. It is known that electron capture by nitrate forms the strongly reducing $\mathrm{NO}_{3}{ }^{2-}$, which in turn can act as a Tc(VII) reducing agent. This is explored in more detail in the next section.

5. Nitrite. A more readily available proxy than solution potentials for a more reducing solution environment.

6. Hydrogen in the vapor space. A direct indicator of the presence of a potential pertechnetate reductant in the tanks. Unfortunately, insufficient tank data was found to correlate even to the relatively limited amount of $\mathrm{n}-\mathrm{Tc}$ data that currently exists.

7. Carbon monoxide in the vapor space. A direct indicator for the presence of an essential ingredient for $\mathrm{Tc}(\mathrm{I})$ carbonyl compound formation. Unfortunately, insufficient tank data was found to correlate even to the relatively limited amount of $\mathrm{n}-\mathrm{Tc}$ data that currently exists.

8. Calculation of the rate of hydrogen generation. An indirect method to estimate the presence of a potential reductant.

9. Calculation of the rate of carbon monoxide rate generation. An indirect method to estimate the presence of a key reagent for conversion of Tc(VII) to Tc(I) carbonyl species. However, unlike hydrogen rate generation, no such correlation has yet been developed.

10. The presence of soluble transuranic elements. A potential proxy indicator for the presence of functionalized organic molecules that can react with metals (in this case the transuranic elements) and keep them soluble in alkaline solution. Functionalized organic molecules are more likely to be able to decompose to form carbon monoxide than simple hydrocarbons, which can comprise part of the total organic carbon measurement noted above. In addition, the presence of complexants is likely to be important in preparing forms of the Tc-carbonyl compounds with long-term stability with respect to air reoxidation of technetium as noted previously.

11. The presence of soluble strontium. See the previous note.

12. Total tank dose. May provide an indicator as to the quantity of energy available to: a) form reducing species for $\mathrm{Tc}(\mathrm{VII})$ and $\mathrm{b}$ ) provide the reactive species that might lead to destruction of organic molecules with concomitant carbon monoxide and/or hydrogen formation.

13. Cesium-137 in the supernatant. This may provide a proxy to describe the energy available for reaction in the solution phase as most of the other relatively abundant, high-energy nuclides (for example, ${ }^{90} \mathrm{Sr},{ }^{60} \mathrm{Co}$, and ${ }^{241} \mathrm{Am}$ ) are generally found only in the sludge layer.

14. Noble metals. Simulant work has indicated that in the presence of the noble metal precipitates, organic complexants themselves can reduce pertechnetate to form alkaline soluble technetium compounds (Bernard et al. 2001).

\subsection{TWINS Data Correlations with Percent $\mathrm{n}$-Tc in Hanford Tank Wastes}

If data were available, plots of each variable mentioned above were prepared (together with a few additional possibilities mentioned below) against the reported percentage of $\mathrm{n}$ - $\mathrm{Tc}$ in the soluble technetium in Hanford Tank supernatants. Representative plots for some poor correlations of variables along with plots for the best correlations will be presented and discussed in the body of the text. The remaining plots are presented in Appendix A. 


\subsubsection{Data Analysis}

Relevant tank waste data, based on actual measurements, were extracted from the Tank Waste Information Network System (TWINS) database for the various tank waste characteristics under consideration to attempt to use a chemistry-based method to evaluate existing tank data to predict the percentage of non-pertechnetate species. Each set of data (for each representative tank examined) was reviewed and scrubbed for suspect data points (e.g., comments regarding quality issues with the measurement), unnecessary duplicate data (as opposed to sample replicates), and gross outliers. In other words, the data were critically examined rather than taking the complete data set.

Data plots were produced for each variable to examine the correlations with previously measured, soluble non-pertechnetate/pertechnetate ratios. Table 1 summarizes, for each representative tank, the values used for the non-pertechnetate percentage based on referenced ratios (i.e., the y axis data point plotted for each representative tank for each variable's data plots). This section provides the plots of that data and discussion. Appendix A, Table A-1 summarizes the results, showing the correlation coefficients from all final plots.

General observations are that

- despite the efforts to cull out suspect data, each variable had a broad range of uncertainty and large error bars. The impact of such large error bars often is compounded by the relatively steep dependence of the percent $\mathrm{n}-\mathrm{Tc}$ on the variable. This leads to situations that can essentially be described as a prediction of between 0 and $100 \% \mathrm{n}$-Tc due to the uncertainty associated with the variable itself.

- TWINS does not include vapor space data usable for this exercise

- with the exception of one possible variable — dose rate (including the specific species ${ }^{137} \mathrm{Cs}$ ) — one must conclude that no correlations were found that are suitable for predictive purposes

- on a positive note, high-dose tanks appear to warrant further investigation. The ${ }^{137} \mathrm{Cs}$ plot and unit liter dose plots yielded interesting plots and correlations that suggest potential usability for predictive purposes. One reason for this optimism is that the measurement uncertainties appear to be much less than those typically observed for the other variables.

\subsubsection{Analysis Results}

Figure 4 provides a typical example for a non-correlating variable. In this instance, the variable examined was the sodium concentration in the waste solution, a variable for which any chemically based correlation is unlikely. As shown in Figure 4, simple inspection illustrates the lack of any correlation. Note also the often large error bars associated with some tanks, in this case AP-104. Note further that the tanks AN107 and AN-102 are highlighted in the plot and correlations are shown both with and without their presence. This analysis is done because these tanks have a relatively unique history and are often referred to as complex concentrate tanks. This is because of the unusually high concentrations of strong metal complexing agents present in these tanks. The presence of such complexants could reasonably result in unusual chemical properties being observed for these tanks; hence these alternative analyses were performed. 


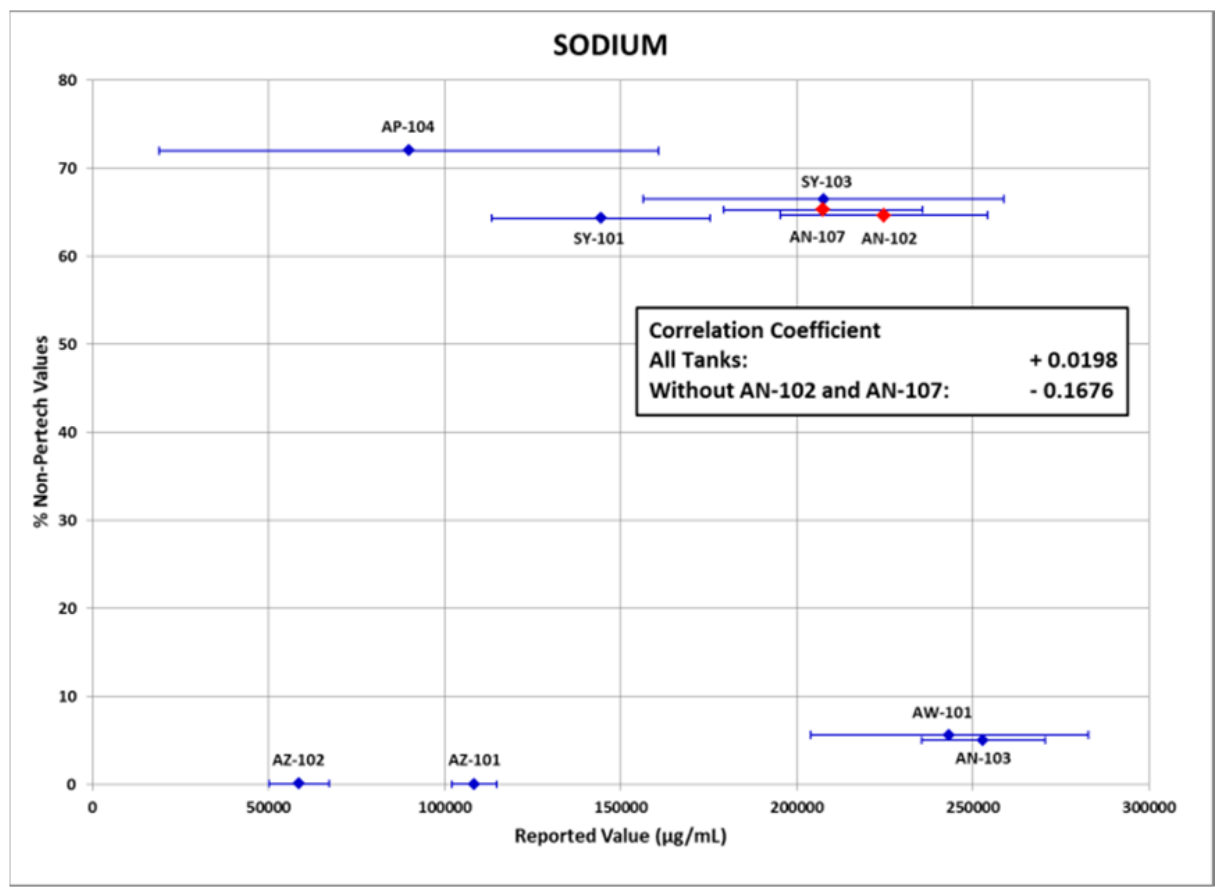

Figure 4: Percent $\mathrm{n}-\mathrm{Tc}$ in Hanford tank supernatants versus measured sodium concentrations

Another interesting non-correlation is that of percent $\mathrm{n}-\mathrm{Tc}$ against the concentration of soluble technetium, shown in Figure 5. Again, the same features described for Figure 4 are seen here.

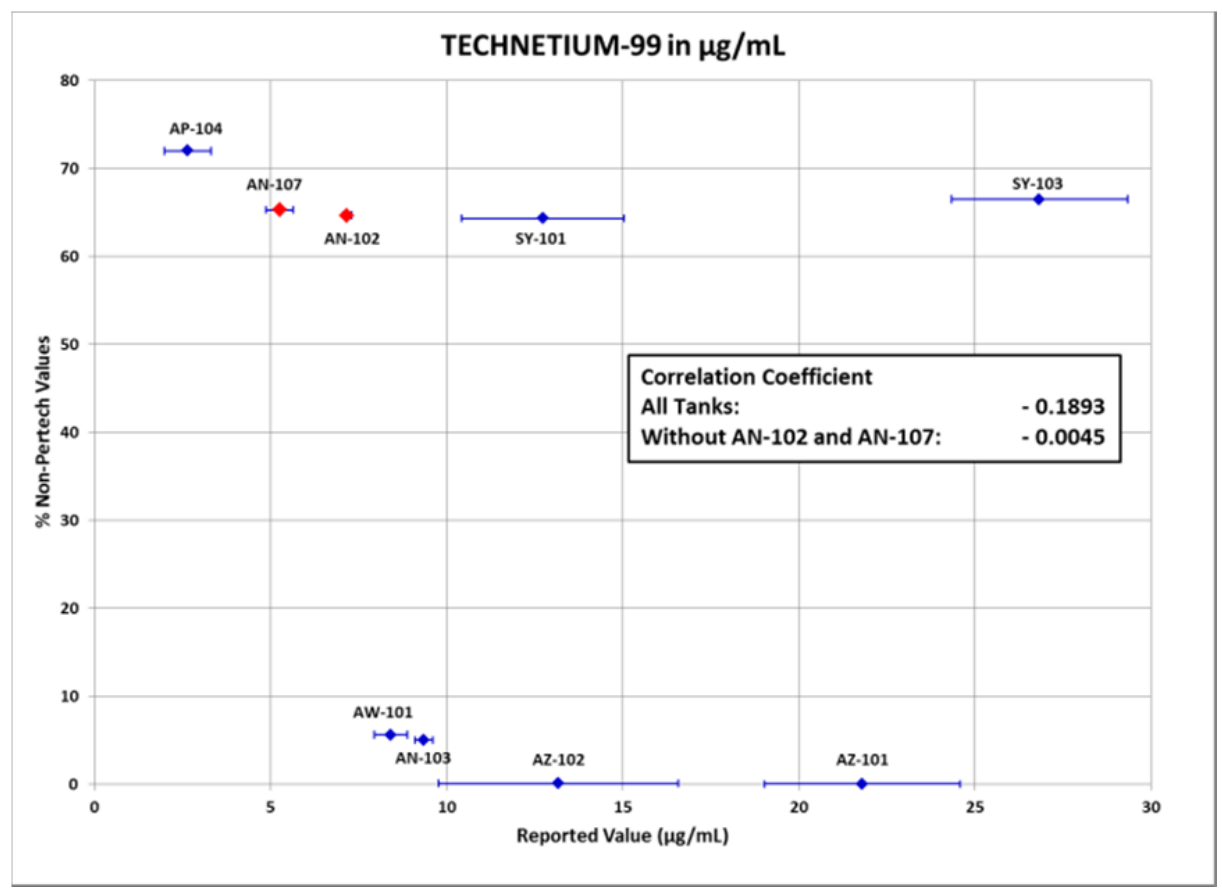

Figure 5: Plot of percent n-Tc versus total soluble technetium 
Perhaps the strongest correlation between a TWINS data variable and percent n-Tc is its relationship to the activity of ${ }^{137} \mathrm{Cs}$ in the supernatant (see Figure 6). Here, an initial inspection of the whole body of data led to removal of the data point for AZ-101. Removal of AZ-101 was done because the percent n-Tc for both AZ-101 and AZ-102 is effectively zero. Therefore, once $0 \% \mathrm{n}$-Tc is reached, further increases will have no effect (as it is negatively correlated). In short, once one gets to either 0 or $100 \%$, further changes do not contribute to understanding the relationship between the two variables; for this reason AZ101 was not included in the correlation.

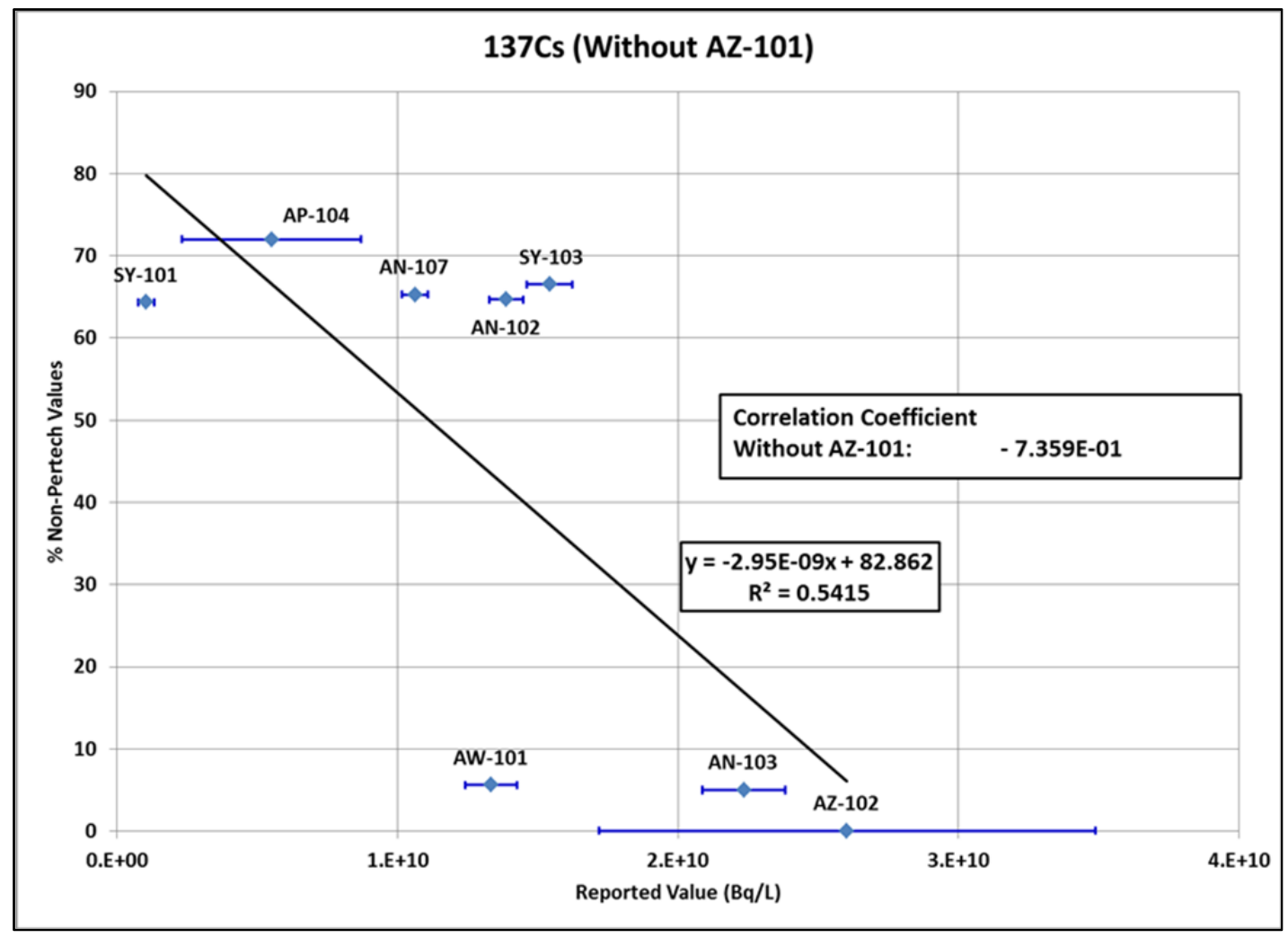

Figure 6: Plot of percent $n-T c$ versus solution concentration of ${ }^{137} \mathrm{Cs}$

Note once again the difficulties in interpreting the results due to uncertainties in the TWINS database. AZ-102, for example, could be predicted as having from 0 to $>20 \% \mathrm{n}$-Tc based solely on the uncertainty in the ${ }^{137} \mathrm{Cs}$ data. At the other end of the scale, AP-104 could be assigned a value from about $50 \%$ to about $70 \%$ again solely based on the uncertainty in the assignment of the concentration of ${ }^{137} \mathrm{Cs}$. So even in the most optimum correlations, $20 \%$ ranges in the prediction of percent $n$-Tc can be assigned and the ranges are likely to be so great as to call into question the usefulness of the prediction.

In summary, there are a large number of chemically plausible variables to account for alkaline-soluble but non-pertechnetate technetium. However, only ${ }^{137} \mathrm{Cs}$, and to a lesser extent the total tank dose, showed potentially interesting correlations. Surprisingly, these variables were inversely correlated to the fraction of alkaline-soluble but non-pertechnetate technetium, which is counterintuitive. 


\subsection{Calculation of Rates Based on Aqueous Radiolysis}

\subsection{Effect of Radiolysis on Water}

Mincher and Mezyk (2009) provide a thorough overview of the effects of beta and gamma radiation (low linear energy transfer) on water and commonly dissolved species that are pertinent to radioactive material processing (e.g., nitrate $\mathrm{NO}_{3}{ }^{-}$). In the waste tank environment, beta and gamma radiation come from the presence of fission products including, but not limited to, ${ }^{137} \mathrm{Cs},{ }^{90} \mathrm{Sr}$, and ${ }^{99} \mathrm{Tc}$ itself. The following radiolytic breakdown of water in the presence of low energy transfer radiation is shown to be (Mincher and Mezyk 2009)

$$
\mathrm{H}_{2} \mathrm{O} \sim \rightarrow[0.28] \cdot \mathrm{OH}+[0.27] \mathrm{e}_{\mathrm{aq}}{ }^{-}+[0.06] \mathrm{H} \cdot[0.07] \mathrm{H}_{2} \mathrm{O}_{2}+[0.27] \mathrm{H}_{3} \mathrm{O}^{+}+[0.05] \mathrm{H}_{2}
$$

Additional reduction and oxidation reactions related to radiolytic products are shown in Table 2.

Table 2: Possible Radiolytic Reductants and Oxidants (Mincher and Mezyk 2009)

\begin{tabular}{|c|c|c|c|}
\hline Species & Example Rxn & Rate Constant & Units \\
\hline Hydrated electron $\left(e_{h}\right)$ red. & $\mathrm{e}_{\mathrm{h}}^{-}+\mathrm{NO}_{3}^{-} \rightarrow \mathrm{NO}_{3}{ }^{2-}$ & $9.7 \times 10^{9}$ & $M^{-1} s^{-1}$ \\
\hline Hydrogen atom $(\mathrm{H} \cdot)$ red. & $\mathrm{H} \cdot+\mathrm{UO}_{2}^{2+} \rightarrow \mathrm{H}^{+}+\mathrm{UO}_{2}^{+}$ & $4.1 \times 10^{7}$ & $M^{-1} s^{-1}$ \\
\hline \multirow[t]{4}{*}{ Hydroxyl radical (.OH) oxid. } & $\mathrm{OH}+\mathrm{Yb}^{2+} \rightarrow \mathrm{OH}^{-}+\mathrm{Yb}^{3+}$ & $3.1 \times 10^{9}$ & $M^{-1} s^{-1}$ \\
\hline & $\mathrm{OH}+\mathrm{An}^{\mathrm{III}} \rightarrow \mathrm{OH}^{-}+\mathrm{An}^{\mathrm{IV}}$ & $2-4 \times 10^{10}$ & $M^{-1} s^{-1}$ \\
\hline & $\mathrm{OH}+\mathrm{An}^{\mathrm{IV}} \rightarrow \mathrm{OH}^{-}+\mathrm{An}^{\mathrm{V}}$ & $1-9 \times 10^{8}$ & $M^{-1} s^{-1}$ \\
\hline & $\mathrm{OH}+\mathrm{An}^{\mathrm{V}} \rightarrow \mathrm{OH}^{-}+\mathrm{An}^{\mathrm{VI}}$ & $1-9 \times 10^{7}$ & $M^{-1} s^{-1}$ \\
\hline Hydrogen peroxide $\left(\mathrm{H}_{2} \mathrm{O}_{2}\right)$ oxid. & $\cdot \mathrm{OH}+\cdot \mathrm{OH} \rightarrow \mathrm{H}_{2} \mathrm{O}_{2}$ & $5.5 \times 10^{9}$ & $M^{-1} s^{-1}$ \\
\hline \multirow[t]{2}{*}{ formation reactions } & $2 \mathrm{HO}_{2} \cdot \rightarrow \mathrm{H}_{2} \mathrm{O}_{2}+\mathrm{O}_{2}$ & $7.6 \times 10^{5}$ & $M^{-1} s^{-1}$ \\
\hline & $\mathrm{O}_{2}^{-}+\mathrm{HO}_{2} \cdot+\mathrm{H}_{2} \mathrm{O} \rightarrow \mathrm{H}_{2} \mathrm{O}_{2}+\mathrm{O}_{2}+\mathrm{OH}^{-}$ & $8.5 \times 10^{7}$ & $M^{-1} s^{-1}$ \\
\hline \multicolumn{4}{|c|}{ Reducing species are consumed under oxidizing and acidic conditions } \\
\hline Scavenging of hydrated electrons & $\mathrm{e}_{\mathrm{h}}^{-}+\mathrm{H}^{+} \rightarrow \mathrm{H}$. & $2.3 \times 10^{10}$ & $M^{-1} s^{-1}$ \\
\hline \multicolumn{4}{|c|}{ Special conditions in alkaline tanks with NOx and carbonate species } \\
\hline Production of $\cdot 0^{-}$radical & $\mathrm{OH}+\mathrm{OH}-\leftrightarrow \cdot \mathrm{O}^{-}+\mathrm{H}_{2} \mathrm{O}$ & $1.3 \times 10^{10}$ & $M^{-1} s^{-1}$ \\
\hline Creation of $\cdot \mathrm{NO}_{3}{ }^{2-}$ & $\mathrm{NO}_{2}^{-}+\cdot \mathrm{O}^{-} \rightarrow \mathrm{NO}_{3}^{2-\cdot}$ & $1.8 \times 10^{7}$ & $M^{-1} s^{-1}$ \\
\hline \multirow[t]{2}{*}{ Carbonate radical generation } & $\mathrm{CO}_{3}^{2-} \sim \sim \mathrm{CO}_{3}{ }^{--}+\mathrm{e}_{\mathrm{aq}}^{-}$ & & \\
\hline & $\mathrm{OH}+\mathrm{CO}_{3}{ }^{2-} \rightarrow \mathrm{CO}_{3}^{--}+\mathrm{OH}^{-}$ & $3.9 \times 10^{8}$ & $M^{-1} s^{-1}$ \\
\hline
\end{tabular}




\subsection{Dominant Rate-Controlling Reactions}

\subsubsection{Pure Water}

In a system where technetium is dissolved in alkaline solution and reducing equivalents are available (e.g., $\left.\mathrm{e}_{\mathrm{h}}{ }^{-}\right), \mathrm{TcO}_{4}{ }^{-}$(pertechnetate) becomes $\mathrm{TcO}_{4}{ }^{2-}$ (technetate) and disproportionates into $\mathrm{Tc}(\mathrm{V})$ and $\mathrm{TcO}_{4}{ }^{-}$. Three reducing equivalents are needed for this reaction series. According to Lukens (2001), $\mathrm{TcO}_{2} \cdot \mathrm{x}_{2} \mathrm{O}$ is the likely reaction product in alkaline solutions where ligands capable of stabilizing reduced technetium species are not present. Under ambient conditions, a small amount of reduced technetium has been observed to stay in solution in these solutions (Lukens et al., 2001). This is a diffusion-controlled reaction (Kissel and Feldberg 1969; Lisbon et al. 1989).

$$
\begin{array}{ll}
\mathrm{TcO}_{4}{ }^{-}+\mathrm{e}_{\mathrm{h}}{ }^{-} \rightarrow \mathrm{TcO}_{4}{ }^{2-} & \mathrm{k}_{3}=2.5 \times 10^{10} \mathrm{M}^{-1} \mathrm{~s}^{-1} ; 2.48 \pm 0.05 \times 10^{10} \mathrm{M}^{-1} \mathrm{~s}^{-1} \text { (Lisbon et al., 1989); } \\
& (1.3-2.5) \times 10^{10} \mathrm{M}^{-1} \mathrm{~s}^{-1} \text { reported by Sekine et al. (2002) } \\
2 \mathrm{TcO}_{4}{ }^{2-} \rightarrow \mathrm{TcO}_{4}{ }^{-}+\mathrm{Tc}(\mathrm{V}) & \mathrm{k}_{4}=1.5 \times 10^{5} \mathrm{M}^{-1} \mathrm{~s}^{-1} \\
2 \mathrm{Tc}(\mathrm{V}) \rightarrow \mathrm{TcO}_{4}{ }^{2-}+\mathrm{Tc}(\mathrm{IV}) & \mathrm{k}_{5}=2.4 \times 10^{3} \mathrm{M}^{-1} \mathrm{~s}^{-1}
\end{array}
$$

The importance of $\mathrm{e}_{\mathrm{h}}{ }^{-}$as a radiolytic reductant for $\mathrm{TcO}_{4}{ }^{-}$is highlighted in a study by Sekine et al. (2002) where solutions containing different concentrations of pertechnetate were exposed to different levels of bremsstrahlung radiation under different solution aeration conditions. In systems where oxidizing scavengers dominated (e.g., $\mathrm{O}_{2}$ and $\mathrm{N}_{2} \mathrm{O}$ saturated), no reduced technetium colloids formed. Higher starting [Tc] were necessary; however, $\mathrm{TcO}_{4}{ }^{-}$was readily reduced to form solid, reduced technetium colloids when $\mathrm{OH}$ radical scavengers were introduced or under aerated conditions, highlighting the importance of hydrated electrons as reducing equivalents. It is important to note that even in systems where the most reduction was observed, not all the hydrated electrons went to reducing $\mathrm{TcO}_{4}^{-}$; there were

\begin{tabular}{|c|c|c|c|c|}
\hline Reaction & Rate Constant & Units & Conditions & Reference \\
\hline \multicolumn{5}{|c|}{ Radiolytic reduction of $\mathrm{TcO}_{4}^{-}$} \\
\hline \multirow[t]{5}{*}{$\mathrm{TcO}_{4}^{-}+\mathrm{e}_{\mathrm{h}}^{-} \rightarrow \mathrm{TcO}_{4}{ }^{2-}$} & $2.5 \times 10^{10}$ & $M^{-1} s^{-1}$ & & (Sekine et al. 2002) \\
\hline & $2.5 \times 10^{10}$ & $M^{-1} s^{-1}$ & & (Lukens et al. 2001) \\
\hline & $2.5 \times 10^{10}$ & $M^{-1} s^{-1}$ & $\mathrm{pH} 13$ & $\begin{array}{c}\text { (Mincher and Mezyk } \\
\text { 2009) }\end{array}$ \\
\hline & $1.30 \times 10^{10}$ & $M^{-1} s^{-1}$ & $\mathrm{pH} 7$ & $\begin{array}{c}\text { (Mincher and Mezyk } \\
\text { 2009) }\end{array}$ \\
\hline & $1.90 \times 10^{10}$ & $M^{-1} s^{-1}$ & pH 6.3 & $\begin{array}{c}\text { (Mincher and Mezyk } \\
\text { 2009) }\end{array}$ \\
\hline
\end{tabular}
some competing reactions. The reaction rates described above are compiled in Table 3.

Table 3: Possible Reduction/Disproportionation Reactions for $\mathrm{TcO}_{4}{ }^{-}$ 


\begin{tabular}{|c|c|c|c|c|}
\hline Reaction & Rate Constant & Units & Conditions & Reference \\
\hline & $2.48 \pm 0.04 \times 10^{10}$ & $M^{-1} s^{-1}$ & $\mathrm{pH} 13$ & (Lisbon et al. 1989) \\
\hline & $2.48 \pm 0.05 \times 10^{10}$ & $M^{-1} s^{-1}$ & $0.10 \mathrm{M}$ & (Deutsch et al. 1978) \\
\hline & \multicolumn{4}{|c|}{$\mathrm{NaOH}$} \\
\hline \multirow[t]{2}{*}{$2 \mathrm{TcO}_{4}^{2-} \rightarrow \mathrm{TcO}_{4}^{-}+\mathrm{Tc}(\mathrm{V})$} & $1.3 \times 10^{8}$ & $M^{-1} s^{-1}$ & & (Sekine et al. 2002) (calc) \\
\hline & $1.5 \times 10^{5}$ & $M^{-1} s^{-1}$ & high $\mathrm{pH}$ & (Lukens et al. 2001) \\
\hline (strongly $\mathrm{pH}$ dependent) & $1.05 \pm 0.09 \times 10^{5}$ & $M^{-1} s^{-1}$ & $\begin{array}{l}\text { unbuff. } \\
\text { water }\end{array}$ & (Lisbon et al. 1989) \\
\hline \multirow[t]{2}{*}{ slower / measurable at high pH } & $1.3 \times 10^{8}$ & $M^{-1} s^{-1}$ & calculated & (Lisbon et al. 1989) \\
\hline & $1.5 \times 10^{5}$ & $M^{-1} s^{-1}$ & $\begin{array}{l}\text { high I.S. and } \\
\text { pH }\end{array}$ & (Kissel and Feldberg 1969) \\
\hline \multirow[t]{2}{*}{$2 \mathrm{Tc}(\mathrm{V}) \rightarrow \mathrm{TcO}_{4}{ }^{2-}+\mathrm{Tc}(\mathrm{IV})$} & $1.3 \times 10^{8}$ & $M^{-1} s^{-1}$ & & (Sekine et al. 2002) \\
\hline & $2.4 \times 10^{3}$ & $M^{-1} s^{-1}$ & & (Lukens et al. 2001) \\
\hline \multicolumn{5}{|l|}{ Radiolytic reduction of nitrate } \\
\hline $\mathrm{NO}_{3}^{-}+\mathrm{e}_{\mathrm{h}}^{-} \rightarrow \mathrm{NO}_{3}^{2-}$ & $9.7 \times 10^{9}$ & $M^{-1} s^{-1}$ & $\begin{array}{l}\text { basic rad } \\
\text { chem }\end{array}$ & (Lukens et al. 2001) \\
\hline $\mathrm{NO}_{3}^{2-}+\mathrm{H}_{2} \mathrm{O} \rightarrow \mathrm{NO}_{2} \cdot+2 \mathrm{HO}^{-}$ & $1 \times 10^{3}$ & $M^{-1} s^{-1}$ & $\begin{array}{l}\text { basic rad } \\
\text { chem }\end{array}$ & (Lukens et al. 2001) \\
\hline $2 \mathrm{NO}_{2} \cdot\left(+\mathrm{H}_{2} \mathrm{O}\right) \rightarrow \mathrm{NO}_{3}^{-}+\mathrm{NO}_{2}^{-}+2 \mathrm{H}^{+}$ & $6 \times 10^{7}$ & $M^{-1} s^{-1}$ & $\begin{array}{l}\text { basic rad } \\
\text { chem }\end{array}$ & (Lukens et al. 2001) \\
\hline \multicolumn{5}{|l|}{ Reduction of Tc(VII) by rad nitrate } \\
\hline $\mathrm{TcO}_{4}^{-}+\mathrm{NO}_{3}{ }^{2--} \rightarrow \mathrm{TcO}_{4}^{2-}+\mathrm{NO}_{3}^{-}$ & $2 \times 10^{7}$ & $M^{-1} s^{-1}$ & & $\begin{array}{l}\text { (Mincher and Mezyk } \\
\text { 2009) }\end{array}$ \\
\hline \multicolumn{5}{|l|}{ Radiolysis and carbonate } \\
\hline $\mathrm{CO}_{3}^{2-}+\mathrm{e}_{\mathrm{h}}^{-} \rightarrow$ products? & $3.9 \times 10^{5}$ & $M^{-1} s^{-1}$ & pH 11.4 & (Ben-Said et al. 2001) \\
\hline $\mathrm{OH} \cdot+\mathrm{Tc}(\mathrm{VI}) \rightarrow \mathrm{Tc}(\mathrm{VII})+\mathrm{OH}^{-}$ & $2 \times 10^{9}$ & $M^{-1} s^{-1}$ & & (Ben-Said et al. 2001) \\
\hline $\mathrm{OH} \cdot+\mathrm{CO}_{3}{ }^{2-} \rightarrow \mathrm{CO}_{3}{ }^{-}+\mathrm{OH}^{-}$ & $3.9 \times 10^{8}$ & $M^{-1} s^{-1}$ & & (Ben-Said et al. 2001) \\
\hline
\end{tabular}

In order to determine which reactions with radiolytic species have the most dominant effect on technetium oxidation state, a series of solution conditions were considered for a number of inorganic components found in the tanks of interest. Specifically, computational methods were used to solve a series of differential equations, which provide information on [Tc] as a function of time when taking 
radiation dose into consideration. The equations used in the model are listed in Appendix B. The intent of this modeling exercise is to help clarify the contribution of dose, nitrate, nitrite, and total inorganic carbon concentrations (assumed here to be carbonate, $\mathrm{CO}_{3}{ }^{2-}$ ) on possible technetium reduction paths in the tanks. Bounding dose values and averaged dissolved species values are derived from the TWINS database; rate constants have been referenced to existing literature.

Looking at Figure 7, the black line represents the rate at which $\mathrm{TcO}_{4}{ }^{-}$(assumed $10 \mu \mathrm{M}$ ) can be reduced to a lower oxidation state in neutral water for low (dashed) and high (solid) dose rates. When no other complexing species are present, hydrated electrons are a strong reductant for pertechnetate and react at a fast rate. Further reduction to Tc(IV) proceeds via the disproportionation reactions described above. Note the greater rate and magnitude of reduction as dose is increased. The dose values here were chosen to reflect the lowest and highest doses observed in the double-shelled tanks of interest at the Hanford Site.

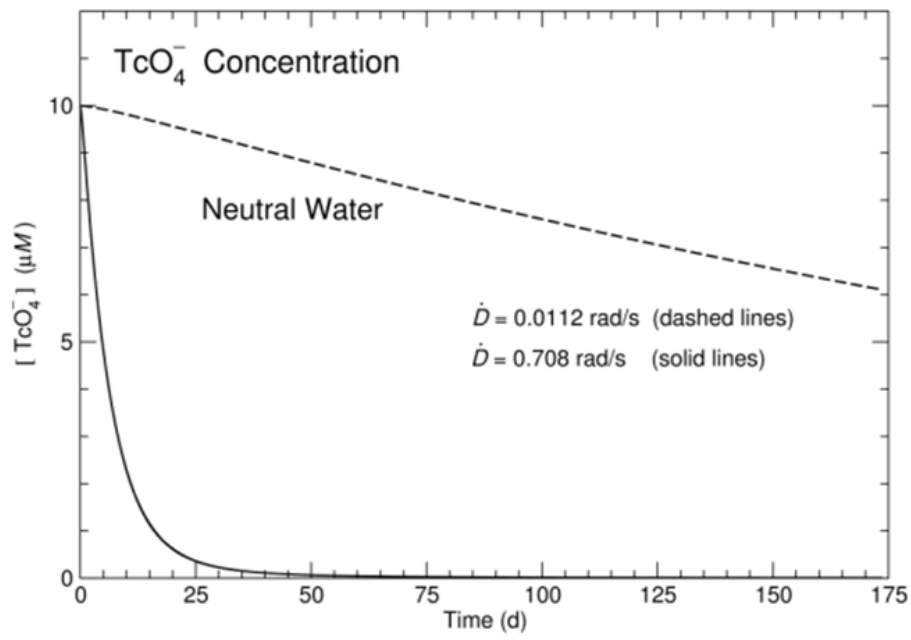

Figure 7: Plot illustrating rate of $\mathrm{TcO}_{4}{ }^{-}$reduction in neutral water as a function of dose Starting $[T c]=10^{-5} M$, based on averages from a select subset (see Table 1) of the TWINS database (AN-102, AN-103, AN-104, AN-107, AP-101, AP-104, AW-101, AY-102, AZ-101, AZ102, SY-101, and SY-103). Doses reflect high and low values observed in these tanks (e.g., AZ101 and SY-102, respectively).

\subsubsection{Effects of Nitrate and Nitrite}

In systems where $\mathrm{NO}_{3}{ }^{-}$(nitrate) is present, as in the tanks, $\mathrm{TcO}_{4}{ }^{-}$must compete with $\mathrm{NO}_{3}{ }^{-}$for reducing equivalents (e.g., $\mathrm{e}_{\mathrm{h}}{ }^{-}$). The reductant-scavenging equations for nitrate are shown below (Lukens et al. 2001, and references therein):
$\mathrm{NO}_{3}{ }^{-}+\mathrm{e}_{\mathrm{h}}{ }^{-} \rightarrow \mathrm{NO}_{3}{ }^{2-}$
$\mathrm{k}_{10}=9.7 \times 10^{9} \mathrm{M}^{-1} \mathrm{~s}^{-1}$
$\mathrm{NO}_{3}{ }^{2-}+\mathrm{H}_{2} \mathrm{O} \rightarrow \mathrm{NO}_{2} \cdot+2 \mathrm{HO}^{-}$
$\mathrm{k}_{11}=17 \times 10^{3} \mathrm{M}^{-1} \mathrm{~s}^{-1}$
$2 \mathrm{NO}_{2} \cdot\left(+\mathrm{H}_{2} \mathrm{O}\right) \rightarrow \mathrm{NO}_{3}{ }^{-}+\mathrm{NO}_{2}{ }^{-}+2 \mathrm{H}^{+}$
$\mathrm{k}_{12}=67 \times 10^{7} \mathrm{M}^{-1} \mathrm{~s}^{-1}$ 
It should be noted that some fraction of reducing equivalents are still available to react with $\mathrm{TcO}_{4}{ }^{-}$; however, nitrate will be a significant competitor. Reduced nitrate $\left(\mathrm{NO}_{3}{ }^{2-}\right)$ on the other hand, can be an effective reductant itself for $\mathrm{TcO}_{4}{ }^{-}$based on the following equation:

$$
\mathrm{TcO}_{4}{ }^{-}+\mathrm{NO}_{3}{ }^{2-} \rightarrow \mathrm{TcO}_{4}{ }^{2-}+\mathrm{NO}_{3}^{-}
$$

Lukens et al. (2001) make the point that, while the reduction of $\mathrm{TcO}_{4}{ }^{-}$by $\mathrm{NO}_{3}{ }^{2-}$ is slower than other electron transfer reactions involving reduced nitrate, it is still faster than the hydrolysis of $\mathrm{NO}_{3}{ }^{2-}$. This reaction is most effective when $\left[\mathrm{NO}_{3}{ }^{-}\right]>\left[\mathrm{TcO}_{4}^{-}\right]$and $\mathrm{O}^{-}$scavengers are present in solution, such as aminopolycarboxylates (e.g., HEDTA, NTA, and IDA). These reactions and associated rates are compiled in Table 3.

In Figure 8, the addition of nitrate to the model shows a significant decrease in the amount of $\mathrm{TcO}_{4}{ }^{-}$that can be reduced, even at high dose, since $\mathrm{NO}_{3}{ }^{-}$is consuming aqueous electrons. The reduction that is observed at high dose is due in part to some hydrated electrons, but much more so due to the formation of radiolytic nitrate $\left(\mathrm{NO}_{3}{ }^{2-}\right)$, that as described by Lukens et al. (2001), is an effective but slower reducing agent for $\mathrm{TcO}_{4}{ }^{-}$in high nitrate environments. Radiolytic nitrate is generated by the interaction of radiolytic $\mathrm{O}^{-}$with $\mathrm{NO}_{2}^{-}$as well; a point that will be illustrated in the following figure. Average values of $\left[\mathrm{NO}_{3}{ }^{-}\right]$were taken from the TWINS database for a specific set of tanks.

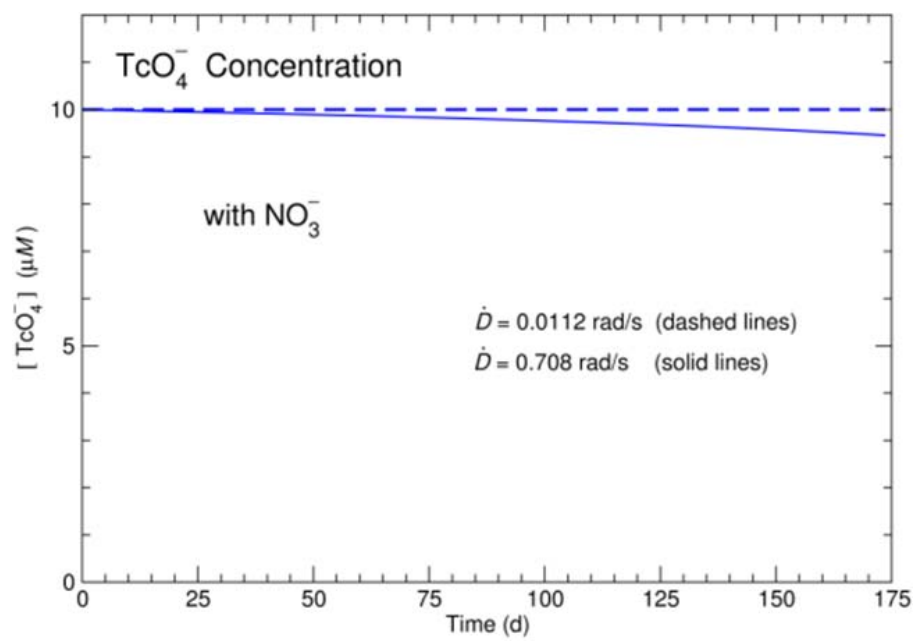

Figure 8: Effect of nitrate on $\mathrm{TcO}_{4}{ }^{-}$reduction rates as a function of dose for a neutral water scenario Average $\left[\mathrm{NO}_{3}^{-}\right]$was set to $2.4 \mathrm{M}$ based on averages from the following double-shelled tanks (see Table 1): AN-102, AN-103, AN-104, AN-107, AP-101, AP-104, AW-101, AY-102, AZ-101, AZ-102, $\mathrm{SY}-101$, and $\mathrm{SY}-103$. Note the difference in $\mathrm{TcO}_{4}{ }^{-}$rates of reduction by $\mathrm{NO}_{3}{ }^{2-}$ versus aqueous electrons (Figure 7).

Since most of the double-shelled tanks of interest reflect very alkaline conditions, the effect of high $\left[\mathrm{OH}^{-}\right]$ is illustrated in Figure 9. Here, the creation of radiolytic nitrate $\left(\mathrm{NO}_{3}{ }^{2-}\right)$ is significantly increased due to the interaction of radiolytically generated nitrite $\left(\mathrm{NO}_{2}{ }^{-}\right)$with $\mathrm{OH}$ via the following equation:

$$
\left.\mathrm{NO}_{2}^{-}+\mathrm{O}^{-} \text {(a.k.a. } \mathrm{OH}\right) \rightarrow \mathrm{NO}_{3}^{2-}
$$


While this reaction only occurs at $1.8 \times 10^{7} \mathrm{M}^{-1} \mathrm{~s}^{-1}$ (Fessenden and Meisel 2000, and references therein), it is driven by the production of radiolytic $\mathrm{O}^{-}$, which increases significantly the presence of high $\left[\mathrm{OH}^{-}\right]$by the following reaction that occurs at $1.3 \times 10^{10} \mathrm{M}^{-1} \mathrm{~s}^{-1}$ (Zehavi and Rabani 1971):

$$
\mathrm{OH}+\mathrm{OH}^{-} \rightarrow \mathrm{O}^{-}+\mathrm{H}_{2} \mathrm{O}
$$

As such, there is more radiolytic nitrate $\left(\mathrm{NO}_{3}{ }^{2-}\right)$ to help drive the reduction of $\mathrm{TcO}_{4}{ }^{-}$under these high $\mathrm{pH}$ conditions.

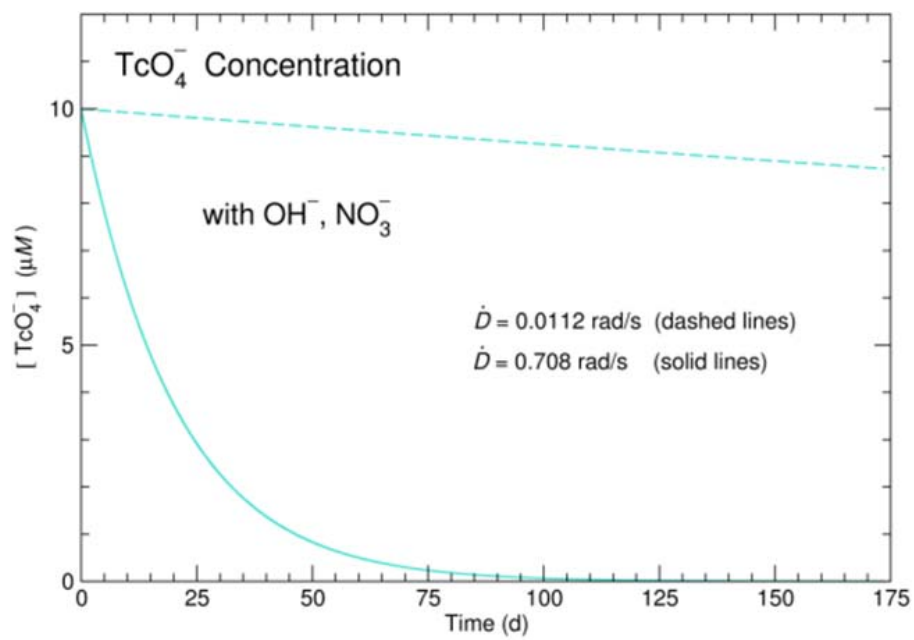

Figure 9: Effect of nitrate $\left[\mathrm{NO}_{3}{ }^{-}\right]$and $\left[\mathrm{OH}^{-}\right]$on $\mathrm{TcO}_{4}{ }_{4}^{-}$reduction rates as a function of dose for a highly alkaline scenario Average $[\mathrm{OH}]$ was set to $2 \mathrm{M}$ based on averages from the following double-shelled tanks (see Table 1): $A N-102, A N-103, A N-104, A N-107, A P-101, A P-104, A W-101, A Y-102, A Z-101, A Z-102$, SY-101, and SY-103. Average $\left[\mathrm{NO}_{3}^{-}\right]$was the same as in Figure $2(2.4 \mathrm{M})$.

Nitrite $\left(\mathrm{NO}_{2}{ }^{-}\right)$, which is also present in the tanks, is a known scavenger of radiolytic $\mathrm{H}, \mathrm{OH}\left(\mathrm{aka}, \mathrm{O}^{-}\right)$, and $\mathrm{H}_{2} \mathrm{O}_{2}$ (Meisel et al. 1991). The following reactions are important for consuming radiolytic $\mathrm{H}$ and $\mathrm{OH}$ by ionic nitrite:

$\mathrm{NO}_{2}{ }^{-}+\mathrm{OH}\left(\right.$ a.k.a. $\left.\mathrm{O}^{-}\right) \rightarrow \cdot \mathrm{NO}_{3}{ }^{2-} \quad\left(1.8 \times 10^{7} \mathrm{M}^{-1} \mathrm{~s}^{-1}\right.$; (Fessenden and Meisel 2000, and references therein))

$\mathrm{NO}_{3}{ }^{2-}+\mathrm{H}_{2} \mathrm{O} \rightarrow \cdot \mathrm{NO}_{2}+2 \mathrm{OH}^{-} \quad\left(1 \times 10^{3} \mathrm{M}^{-1} \mathrm{~s}^{-1}\right.$; (Lukens et al. 2001, and references therein) $)$

$\mathrm{NO}_{2}^{-}+\mathrm{H} \cdot \rightarrow \mathrm{NO} \cdot+\mathrm{OH}-\quad\left(7.1 \times 10^{8} \mathrm{M}^{-1} \mathrm{~s}^{-1} ;(\right.$ Meisel et al. 1991, 2001 and references therein $\left.)\right)$

Since the production of $\mathrm{NO}_{3}{ }^{2-}$ from nitrite and radiolytic $\mathrm{O}^{-}$occurs at a rate that is orders of magnitude faster than the decomposition of $\mathrm{NO}_{3}{ }^{2-}$ into nitrite and $\mathrm{OH}^{-}$, the presence of nitrite contributes to the reduction of $\mathrm{TcO}_{4}{ }^{-}$in a similar fashion to the rate curves illustrated in Figure 9. Under high $\left[\mathrm{OH}^{-}\right]$ conditions, the same equation as described above applies, where the formation of radiolytic $\mathrm{O}^{-}$drives the formation of $\mathrm{NO}_{3}{ }^{2-}$ :

$\mathrm{OH}+\mathrm{OH}^{-} \rightarrow \mathrm{O}^{-}+\mathrm{H}_{2} \mathrm{O} \quad\left(1.3 \times 10^{10} \mathrm{M}^{-1} \mathrm{~s}^{-1} ;\right.$ (Zehavi and Rabani 1971)) 
Note that in Figure 9, the concentration of $\mathrm{NO}_{2}{ }^{-}$is only that generated by the radiolysis of $\mathrm{NO}_{3}{ }^{-}$.

\subsubsection{Effects of carbonate}

Similar to nitrate $\left(\mathrm{NO}_{3}^{-}\right)$, the carbonate anion can also be affected by radiolysis according to the following reaction (Mincher and Mezyk 2009, and references therein):

$$
\mathrm{CO}_{3}^{2-}-\sim \sim \rightarrow \mathrm{CO}_{3} \cdot{ }^{-}+\mathrm{e}_{\mathrm{h}}^{-} \text {. }
$$

The carbonate radical can also be formed by interaction with the OH radical (Mincher and Mezyk 2009, and references therein):

$$
\mathrm{OH}+\mathrm{CO}_{3}{ }^{2-} \rightarrow \mathrm{CO}_{3} \cdot{ }^{-}+\mathrm{OH}^{-} \quad k=3.9 \times 10^{8} \mathrm{M}^{-1} \mathrm{~s}^{-1} .
$$

Presumably, the tanks at Hanford can be considered open to the atmosphere; as such, equilibrium could be reached with atmospheric $\mathrm{CO}_{2}$ values. Under strongly alkaline conditions, $\mathrm{CO}_{3}{ }^{2-}$ would be the dominant carbonate species. However, the tanks also have varying amounts of inorganic carbon additions that can lead to higher concentrations of $\left[\mathrm{CO}_{3}{ }^{2-}\right]$ than atmospheric equilibrium alone. According to BenSaid et al. (Ben-Said et al. 2001), the amount of reduced technetium in an irradiated system is less when carbonate is present than without, at least in a system with formate $\left(\mathrm{HCOO}^{-}\right)$present as a scavenger of certain radiolytic products (e.g., $\cdot \mathrm{OH}$ and $\cdot \mathrm{H})$. Radiolytic $\mathrm{CO}_{3} \cdot{ }^{\cdot}$ is also an oxidant that can serve to reoxidize partially reduced technetium based on the following interaction (Ben-Said et al. 2001):

$$
\mathrm{CO}_{3}{ }^{-}+\mathrm{Tc}(\mathrm{VI}) \rightarrow \mathrm{Tc}(\mathrm{VII})+\mathrm{CO}_{3}{ }^{2-}
$$

As such, it is important to consider the effects of radiolysis products on carbonate since these oxidizing effects may be in competition with radiolytic reducing effects in the tank environment. Rate constants are presented in Table 2 and Table 3, while in Figure 10, the competing effects of carbonate and its radiolytic by-products are computed in the presence of $\mathrm{NO}_{3}{ }^{-}$and high $\mathrm{OH}^{-}$.

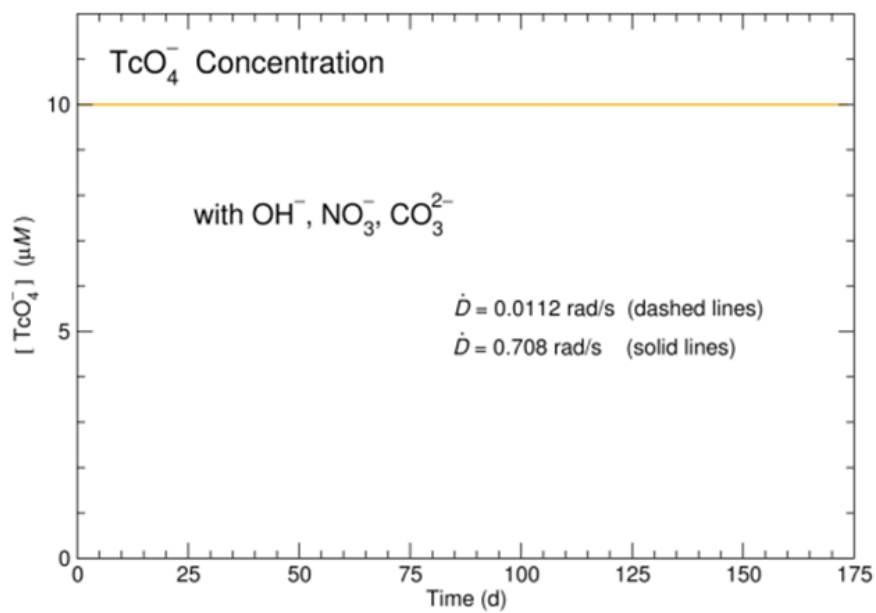

Figure 10: Effect of carbonate $\left(\left[\mathrm{CO}_{3}{ }^{2-}\right]=1 \mathrm{M}\right)$ on $\mathrm{TcO}_{4}{ }^{-}$reduction rates in presence of $\left.2.4 \mathrm{M}^{-} \mathrm{NO}_{3}{ }^{-}\right]$and $2 \mathrm{M}\left[\mathrm{OH}^{-}\right]$ 
Constituent values are based on averages from these selected tanks (see Table 1): AN-102, AN103, AN-104, AN-107, AP-101, AP-104, AW-101, AY-102, AZ-101, AZ-102, SY-101, and SY-103. No significant differences are observed for low dose and high dose conditions.

In the presence of high carbonate concentrations (e.g., $1 \mathrm{M}$, average from tanks of interest), carbonate is consuming free $\mathrm{OH}$ radicals that in turn depletes the formation of $\mathrm{O}^{-}$radicals, which are important for generating more $\mathrm{NO}_{3}{ }^{2-}$ via the reaction $\mathrm{NO}_{2}{ }^{-}+\mathrm{O}^{-} \rightarrow \mathrm{NO}_{3}{ }^{2-}$. In conjunction with the ability of radiolytic carbonate to oxidize technetium back to $\mathrm{TcO}_{4}^{-}$, the radiolytic reduction of pertechnetate is hampered. However, addition of nitrite $\left(\mathrm{NO}_{2}{ }^{-}\right)$to the model at tank-relevant concentrations (e.g., $\left.1.5 \mathrm{M}\right)$ allows for more generation of $\mathrm{NO}_{3}{ }^{2-}$ and this reduction mechanism becomes favorable again (see magenta line at high dose in Figure 11). In the plot, $t_{1 / 2}$ is the amount of time it takes for half of the $\mathrm{TcO}_{4}{ }^{-}$to become reduced (not necessarily to form $\mathrm{Tc}(\mathrm{IV})$, but to no longer be $\mathrm{TcO}_{4}{ }^{-}$).

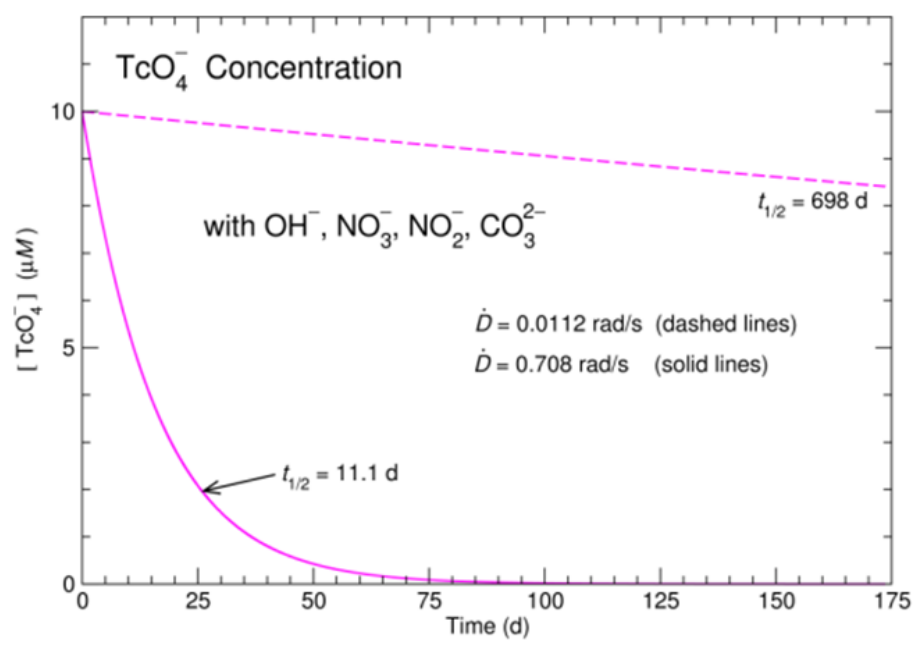

Figure 11: Effect of nitrite $\left(\left[\mathrm{NO}_{2}{ }^{-}\right]=1.5 \mathrm{M}\right)$ on $\mathrm{TcO}_{4}{ }^{-}$reduction rates in the presence of $1 \mathrm{M}\left[\mathrm{CO}_{3}{ }^{2-}\right], 2.4$ $\mathrm{M}\left[\mathrm{NO}_{3}^{-}\right]$, and $2 \mathrm{M}\left[\mathrm{OH}^{-}\right]$ Constituent values are based on averages from these selected tanks (see Table 1): $A N-102, A N-$ 103, AN-104, AN-107, AP-101, AP-104, AW-101, AY-102, AZ-101, AZ-102, SY-101, and SY-103. The addition of $\mathrm{NO}_{2}^{-}$highlights the importance of the $\mathrm{NO}_{3}{ }^{2-}$ species in reducing $\mathrm{TcO}_{4}{ }^{-}$under the system considered here.

\subsubsection{Combined Effects and Dominant Reactions}

Under typical waste storage tank conditions of high $\mathrm{pH}$ and high nitrate, nitrite, the radiochemical yield in Eq. 8 is primarily dependent on the presence of the nitrate radical $\mathrm{NO}_{3}^{2-}$. Equation 8 is modified after Lukens et al. (2001).

In terms of the dose rate $\dot{D}$, expressions for the effective rate constant $k_{\text {red }}$ and half-life $t_{1 / 2}$ are given in Eqs. 9 and 10, which account for how the solution chemistry influences the formation of $\mathrm{NO}_{3}^{2-}$. Here $t_{1 / 2}$ refers to the amount of time it takes to reduce half the technetium inventory in the tank supernatant (e.g., assuming $\mathrm{TcO}_{4}{ }^{-}$as the starting species, but not explicitly $\mathrm{Tc}(\mathrm{IV})$ as the end point). 
For high concentrations of $\mathrm{OH}^{-}$, the generation of $\mathrm{OH}$ radicals and $\mathrm{H}$ radicals and aqueous electrons generate $\mathrm{NO}_{3}^{2-}$, while the presence of $\mathrm{CO}_{3}^{2-}$ depletes $\mathrm{OH}$ radicals available to produce $\mathrm{NO}_{3}^{2-}$. Along with $\mathrm{CO}_{3}^{2-}$ it is expected that organic species will also compete for $\mathrm{OH}$ radicals as well as form complexes with reduced forms of technetium. 


$$
\begin{gathered}
g\left(-\mathrm{TcO}_{4}^{-}\right)=\frac{k_{119}\left[\mathrm{TcO}_{4}^{-}\right]}{3\left(k_{123}\left[\mathrm{H}_{2} \mathrm{O}\right]+k_{119}\left[\mathrm{TcO}_{4}^{-}\right]\right)}\left[g\left(e_{a q}^{-}\right)+g(\mathrm{H} \cdot)+g(\mathrm{OH})\left(1-\frac{k_{84}\left[\mathrm{CO}_{3}^{2-}\right]}{k_{84}\left[\mathrm{CO}_{3}^{2-}\right]+\frac{k_{11} k_{125}\left[\mathrm{OH}^{-}\right]\left[\mathrm{NO}_{2}^{-}\right]}{k_{12}+k_{125}\left[\mathrm{NO}_{2}^{-}\right]}}\right)\right] \\
k_{\mathrm{red}}=\frac{k_{119} \dot{D}}{3 k_{123}\left[\mathrm{H}_{2} \mathrm{O}\right]}\left[g\left(e_{a q}^{-}\right)+g(\mathrm{H} \cdot)+g(\cdot \mathrm{OH})\left(1-\frac{k_{84}\left[\mathrm{CO}_{3}^{2-}\right]}{\left.\left.k_{84}\left[\mathrm{CO}_{3}^{2-}\right]+\frac{k_{11} k_{125}\left[\mathrm{OH}^{-}\right]\left[\mathrm{NO}_{2}^{-}\right]}{k_{12}+k_{125}\left[\mathrm{NO}_{2}^{-}\right]}\right)\right] \text {(Eq. 9) }}\right.\right. \\
t_{\frac{1}{2}}=\frac{\ln 2+\frac{k_{119}\left[\mathrm{TcO}_{4}^{-}\right]_{0}}{2 k_{123}\left[\mathrm{H}_{2} \mathrm{O}\right]}}{k_{\mathrm{red}}}
\end{gathered}
$$


In Figure 12, a final case is considered, a low $\mathrm{OH}^{-}$case (e.g., less sodium hydroxide added to the tanks) where the carbonate term in Eq. 9 becomes significant. Under these conditions, the radiolytic reduction of $\mathrm{Tc}(\mathrm{VII})$ is suppressed due to the lack of $\mathrm{OH}$, which is important for forming $\mathrm{O}^{-}, \mathrm{NO}_{3}{ }^{2-}$, and even hydrated electrons at a lower rate.

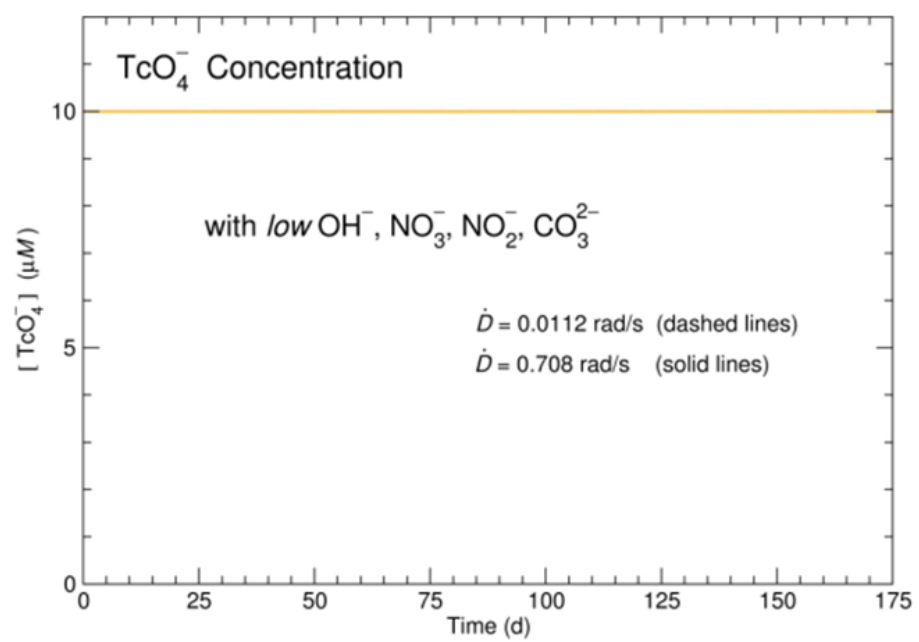

Figure 12: Effect of low $[\mathrm{OH}-](0.01 \mathrm{M})$ on $\mathrm{TcO}_{4}{ }^{-}$reduction rates in the presence of $1 \mathrm{M}^{-}\left[\mathrm{CO}_{3}{ }^{2-}\right], 2.4 \mathrm{M}$ $\left[\mathrm{NO}_{3}^{-}\right]$, and $1.5 \mathrm{M}\left[\mathrm{NO}_{2}^{-}\right]$ Constituent values are based on averages from the following selected tanks (see Table 1): $A N$ 102, AN-103, AN-104, AN-107, AP-101, AP-104, AW-101, AY-102, AZ-101, AZ-102, SY-101, and SY-103. NOTE: This final condition does not appear in the flagged tanks; however, there are some tanks in the total inventory that reflect this low [OH] scenario.

\subsection{Summary}

In this section, only the effects of radiolysis on inorganic species in double-shelled tanks of interest were considered when calculating reduction rates for $\mathrm{TcO}_{4}{ }^{-}$. It is important to note that while this model is internally consistent, it is not entirely comprehensive based on the body of published work in this field and results could change as more reactions are taken into consideration. Rather, these results are meant to illustrate the potential application of competitive rate analysis, whereby the reducing effect of specific tank constituents on $\mathrm{TcO}_{4}^{-}$can be quantified based on existing rate constants. The rate constants used in calculation of $\mathrm{Tc}(\mathrm{VII})$ reduction rates are provided in Appendix B.

In Figure 13, all previously considered scenarios are overlain on the same plot to allow the relative rates of $\mathrm{TcO}_{4}{ }^{-}$reduction to be visualized. To recap, under neutral water conditions in the absence of strong oxidants or inorganic complexants, the reduction of $\mathrm{TcO}_{4}{ }^{-}$is driven mainly by the consumption of hydrated electrons (black line). In the presence of $\mathrm{NO}_{3}{ }^{-}$, hydrated electrons get consumed by nitrate at a faster rate than by $\mathrm{TcO}_{4}^{-}$, leading to less reduction (dark blue line). However, under high $\mathrm{NO}_{3}{ }^{-}$or $\mathrm{NO}_{2}{ }^{-}$ conditions, high $\left[\mathrm{OH}^{-}\right]$is an important driver for the generation of radiolytic $\mathrm{O}^{-}$, which leads to a level of $\mathrm{NO}_{3}{ }^{2-}$ formation that, in turn, can reduce $\mathrm{TcO}_{4}{ }^{-}$(light blue and magenta lines). The addition of total inorganic carbon (considered only as $\mathrm{CO}_{3}{ }^{2-}$ here) hampers the formation of $\mathrm{NO}_{3}{ }^{2-}$ at first by consuming $\mathrm{OH}$ with the $\mathrm{CO}_{3}{ }^{-}$radical (orange line). Increasing $\mathrm{NO}_{2}{ }^{-}$concentration leads to competition or radiolytic $\mathrm{OH}$ and once again drives $\mathrm{TcO}_{4}{ }^{-}$reduction (magenta line). Finally, under low $\left[\mathrm{OH}^{-}\right]$, less $\mathrm{O}-$ and 
subsequently less $\mathrm{NO}_{3}{ }^{2-}$ is formed, which then inhibits reduction of $\mathrm{TcO}_{4}{ }^{-}$. It is also important to note that dose plays a significant role in most cases regarding how much technetium can be reduced; a term that can easily be adjusted using this type of modeling approach.

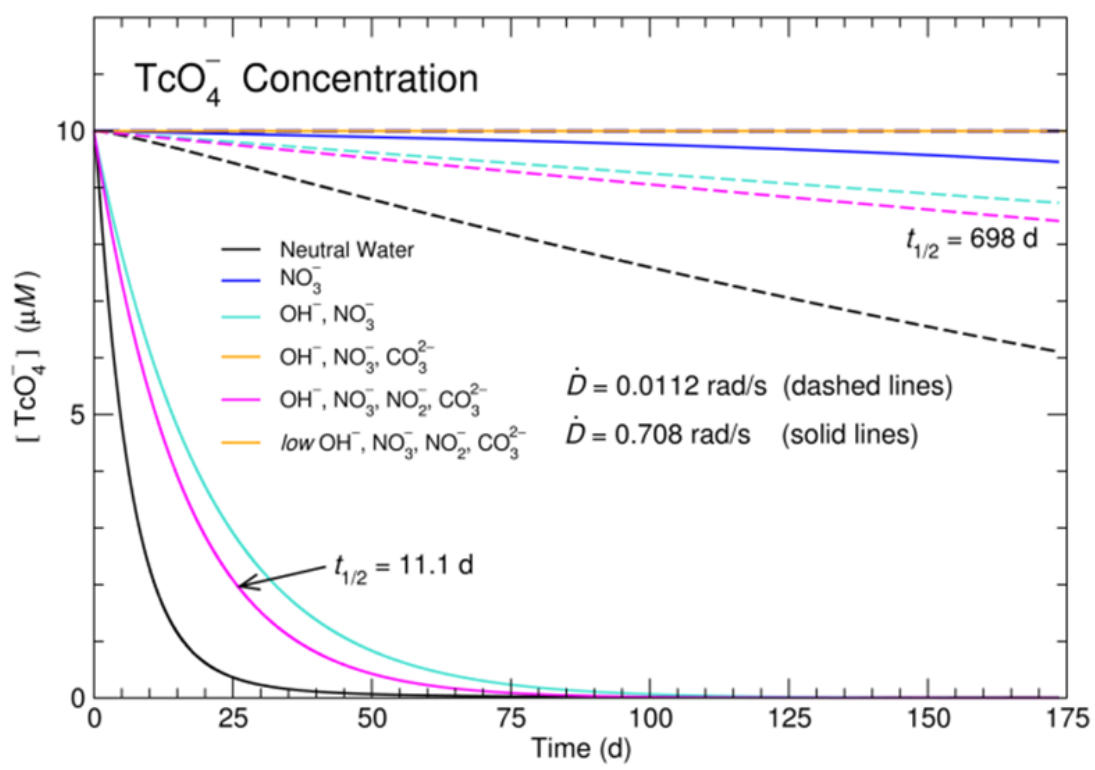

Figure 13: Plot showing $\mathrm{Tc}(\mathrm{VII}) \mathrm{O}_{4}{ }^{-}$concentration in solution as a function of dose (high, solid; low, dashed) and inorganic species of interest

Concentrations are as follows: $\mathrm{Tc}$ (VII) $10 \mu \mathrm{M} ; \mathrm{NO}_{3}^{-} 2.4 \mathrm{M} ; \mathrm{NO}_{2}^{-} 1.5 \mathrm{M} ; \mathrm{CO}_{3}{ }^{2-} 1 \mathrm{M}$; and $\mathrm{OH} 2 \mathrm{M}$; and, low $\mathrm{OH}^{-} 0.01 \mathrm{M}$. Values reflect averages from supernatant inventory of double-shelled tanks of interest (see Table 1): $A N-102, A N-103, A N-104, A N-107, A P-101, A P-104, A W-101, A Y-102$, AZ-101, AZ-102, SY-101, and SY-103. Doses reflect high and low values observed in these tanks (e.g., AZ-101 and SY-102, respectively). Rate constants used to generate the curves are shown in Appendix $B$. 


\subsection{Preparation, Characterization, and Initial Stability Evaluation of $\left[(\mathrm{CO})_{3} \mathrm{Tc}\left(\mathrm{H}_{2} \mathrm{O}\right)_{3}\right]^{+}$}

Identifying the amount of $n-T c$ is extremely useful for estimating the amount of technetium that can currently be removed from the Hanford tank supernatants, and indeed was the focus of the investigation described in Section 2.0. However, if a tank process-friendly method were to exist to effectively convert the $\mathrm{n}-\mathrm{Tc}$ to pertechnetate, it would also be useful as the only process needed to remove all soluble technetium independent of its initial state in the supernatant. For this reason, scoping studies directed at evaluating candidate oxidation processes for the $\mathrm{n}$-Tc species in alkaline solution were performed.

Research into this area is not new. Extensive work on converting n-Tc to pertechnetate was done by Schroeder, et al. on actual Hanford tank (SY-103 and SY-101) supernatants (Schroeder et al. 2001, Schroeder et al. 1998). Candidate oxidants tested included persulfate $\left(\mathrm{S}_{2} \mathrm{O}_{8}{ }^{2-}\right)$, (with and without a silver, cerium, or copper catalyst), permanganate $\left(\mathrm{MnO}_{4}{ }^{-}\right)$, hypochlorite $\left(\mathrm{OCl}^{-}\right), \mathrm{Pb}(\mathrm{IV}), \mathrm{V}(\mathrm{V})$, bromate $\left(\mathrm{BrO}_{3}{ }^{-}\right)$, bismuthate $\left(\mathrm{BiO}_{3}{ }^{-}\right)$, hydrogen peroxide $\left(\mathrm{H}_{2} \mathrm{O}_{2}\right)$, hypochlorite/hydrogen peroxide, ozone $\left(\mathrm{O}_{3}\right)$, photolysis (with and without persulfate, or hydrogen peroxide), and ferrate $\left(\mathrm{FeO}_{4}{ }^{2-}\right)$.

These studies concluded that persulfate and ozone were the best of the chemical oxidants and photolysis, particularly when combined with persulfate, was the most successful.

In any practical application, the addition of large amounts of solid reagents is problematic. For this reason, performing scoping studies using only materials that will not add mass to the waste stream for conversion of $n-T c$ back to pertechnetate would be useful. Investigation of the rate of reoxidation of known candidate $n-T c$ compounds such as $\left[(\mathrm{CO})_{3} \mathrm{Tc}\left(\mathrm{H}_{2} \mathrm{O}\right)_{3}\right]^{+}$and its derivatives in mildly alkaline solutions would be a useful first step. This section describes our initial steps to evaluate the effectiveness of simply aerated solutions at converting the Tc(I) carbonyl species to pertechnetate in the presence and absence of concomitant photolysis.

\subsection{Determination of Molar Absorptivity of $\mathrm{TcO}_{4}^{-}$}

Ultraviolet-visible (UV-vis) spectrophotometric measurements of the technetium solutions were conducted using a USB2000-series charge-coupled device array spectrophotometer (Ocean Optics, Inc.) with a $180-n m$ to $880-n m$ scanning range coupled with a deuterium light source DH2000 MIKROPACK (Ocean Optics, Inc.). The solutions were held in quartz 1-cm cuvettes. The UV spectrum of the aqueous $\mathrm{TcO}_{4}{ }^{-}$solution exhibited two strong bands with maxima at $248 \mathrm{~nm}$ and $288 \mathrm{~nm}$ (Figure 14, left). The concentration of the $\mathrm{TcO}_{4}{ }^{-}$stock solution was determined by liquid scintillation counting, using a ${ }^{99} \mathrm{Tc}$ specific activity of $0.017 \mathrm{Ci} / \mathrm{g}^{-1}$ (de Gul et al., 1993). To correlate the absorbance intensity with $\mathrm{TcO}_{4}{ }^{-}$ concentration, a series of $\mathrm{TcO}_{4}{ }^{-}$solutions in the $0.07-0.15 \mathrm{mM}$ concentration range prepared in a carbonate buffer at $\mathrm{pH}$ of about 11 was subjected to UV measurements (Figure 14, left). Observed linear Beer's plots allowed for calculation of the molar absorptivity for both the 248-nm and 288-nm bands using Eq. 11,

$$
\mathrm{A}=\varepsilon \mathrm{\varepsilon l}\left[\mathrm{TcO}_{4}^{-}\right]
$$


where $\mathrm{A}, \varepsilon, 1$, and $\left[\mathrm{TcO}_{4}{ }^{-}\right]$are absorbance, molar absorptivity, optical pathlength, and $\mathrm{TcO}_{4}{ }^{-}$molar concentration, respectively. The molar absorptivities of the 248-nm and 288-nm bands of $\mathrm{TcO}_{4}{ }^{-}$were determined to be $5600 \mathrm{M}^{-1} \mathrm{~cm}^{-1}$ and $2200 \mathrm{M}^{-1} \mathrm{~cm}^{-1}$, respectively (Figure 14, right), in reasonable agreement with the corresponding values of 6165 and $2316 \mathrm{M}^{-1} \mathrm{~cm}^{-1}$ reported elsewhere [Rulfs et al., 1967]. These experiments confirmed that reduction conversion of $\mathrm{TcO}_{4}{ }^{-}$to the $\mathrm{Tc}(\mathrm{I})$ tricarbonyl complex during the reaction can be conveniently quantified and monitored by UV spectroscopy at least indirectly via the disappearance of spectral features characteristic of $\mathrm{TcO}_{4}{ }^{-}$.

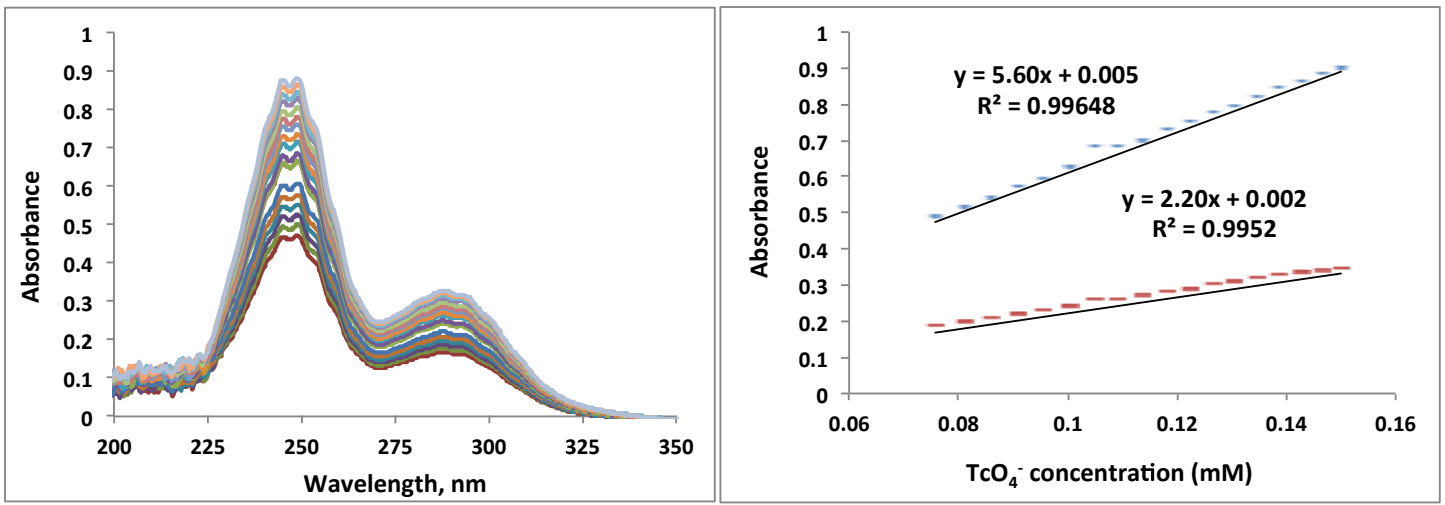

Figure 14: UV absorbance spectral layout and corresponding Beer's plots (left and right respectively)

\subsection{Synthesis of $\mathrm{fac}-\mathrm{Tc}(\mathrm{CO})_{3}{ }^{+}$}

The experimental scope for this study was focused in part on preliminary testing of the literature synthetic route to obtain analytical quantities of $f a c-\mathrm{Tc}(\mathrm{CO})_{3}{ }^{+}$as its triaqua complex. We chose the synthetic procedure reported by Alberto et al. (1998) based on its relative simplicity, reported high yield compatible with the required quantities of the product compound, and safety considerations. In this method, Tc(I) tricarbonyl species are synthesized by reducing $\mathrm{TcO}_{4}{ }^{-}$with sodium borohydride in the presence of $\mathrm{CO}$ under alkaline conditions and elevated temperature $\left(50-80^{\circ} \mathrm{C}\right)$ as shown in Eq. 12 below:

$$
\mathrm{TcO}_{4}^{-}+\mathrm{mH}_{2} \mathrm{O} \underset{\text { Ligand }^{\mathrm{n}-}}{\stackrel{\mathrm{NaBH}_{4}, \mathrm{CO}}{\longrightarrow}}\left[\mathrm{Tc}(\mathrm{CO})_{3}{ }^{+} \cdot\left(\mathrm{H}_{2} \mathrm{O}\right)_{\mathrm{m}} \cdot \text { Ligand }^{\mathrm{n}-}\right]^{1-\mathrm{n}}
$$

where $m=1-3$ and $n$ is the anion charge. The assembled reaction apparatus is shown in Figure 15. It consisted of a round-bottom, tri-neck flask equipped with a condenser to prevent the loss of solvent during heating. A CO tank was installed in the non-radiological fume hood adjacent to the radiological fume hood in which the reaction apparatus was located. A CO transfer line was installed between the fume hoods. To introduce $\mathrm{CO}$ into the reaction apparatus, a long needle was inserted into the flask through a septum and connected to the $\mathrm{CO}$ transfer line. The inlet gas line was passed initially through a water bubbler to humidify the $\mathrm{CO}$ prior to introduction to the reaction apparatus and so prevent concentration changes due to solvent losses. To closely monitor the CO flux during the reaction and prevent pressure build up in the reaction flask, a gas outlet line consisting of a wide-bore short needle connected to a gas bubbler filled with water was constructed. The reaction apparatus was placed in a 
heating mantle equipped with a temperature controller unit. To monitor the temperature, a thermocouple was inserted in the reaction mixture.

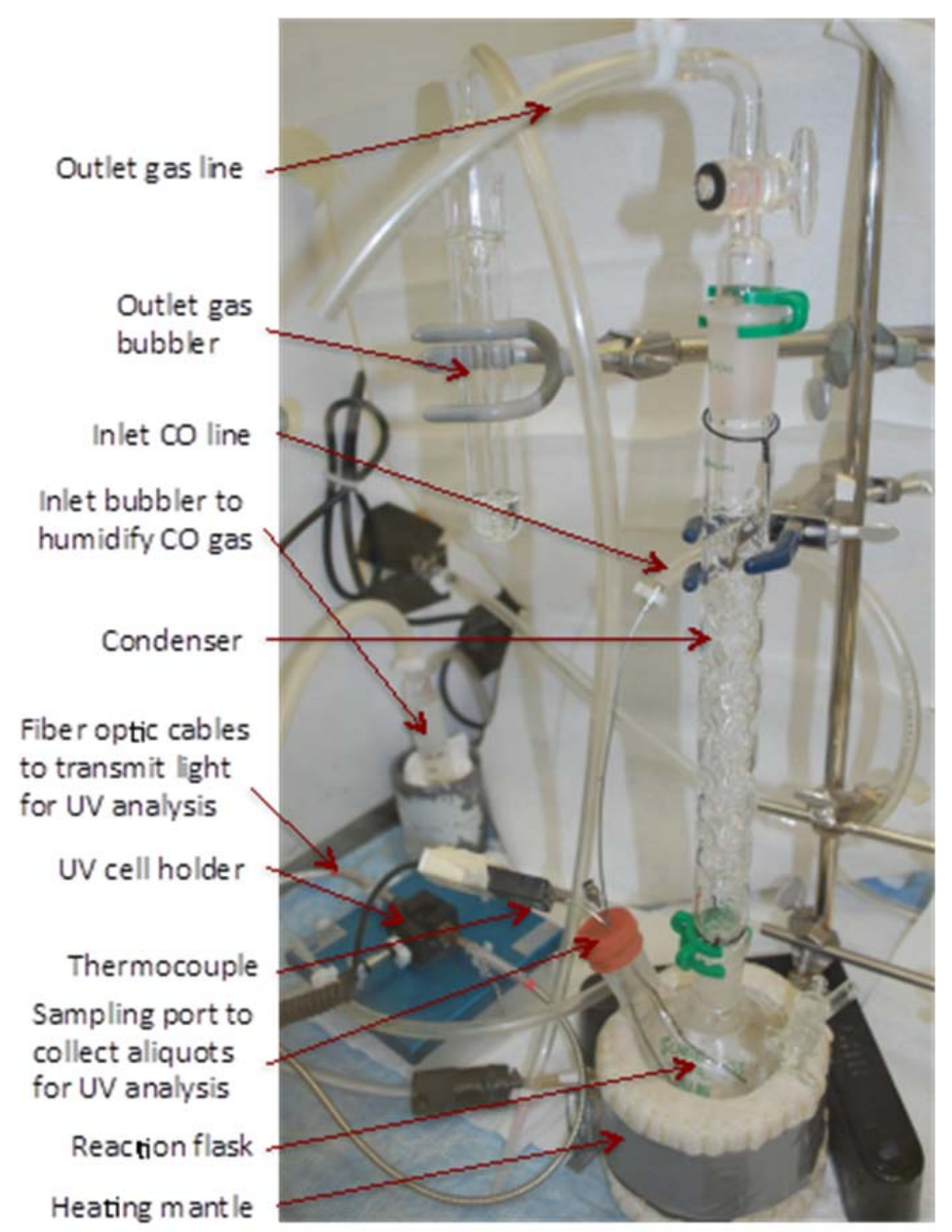

Figure 15: Experimental apparatus used for synthesis of $\mathrm{Tc}(\mathrm{CO})_{3}{ }^{+}$via reduction of $\mathrm{TcO}_{4}{ }^{-}$

The reaction apparatus was loaded with $\mathrm{Na}_{2} \mathrm{CO}_{3}(0.040 \mathrm{~g}, 0.38 \mathrm{mmol})$ and $\mathrm{NaBH}_{4}(0.050 \mathrm{~g}, 1.3 \mathrm{mmol})$, dissolved in $50 \mathrm{~mL}$ of water, and the $\mathrm{pH}$ verified to be 11 . Carbon monoxide then was flushed through the mixture for about 1 hour. Aqueous $6 \mathrm{mM} \mathrm{KTcO}_{4}$ solution $(15 \mathrm{~mL}, 0.09 \mathrm{mmol})$ was added into the flask by a syringe and $\mathrm{CO}$ was further bubbled through the reaction mixture for 30 minutes. Prior to heating, an aliquot of this reaction mixture was removed and its UV spectrum acquired (see Figure 16). Comparison of the spectra corresponding to the $\mathrm{KTcO}_{4}$ solution in the $\mathrm{Na}_{2} \mathrm{CO}_{3}$ buffer with and without borohydride being present indicated that the latter (borohydride) also exhibits a strong absorption profile in the UV region with maximum at about $228 \mathrm{~nm}$ and partially overlaps with the $248-\mathrm{nm}$ band of $\mathrm{TcO}_{4}$. The 288-nm band of $\mathrm{TcO}_{4}{ }^{-}$is not obstructed by the $\mathrm{NaBH}_{4}$ spectrum and can be used to monitor progression of the reduction reaction. 


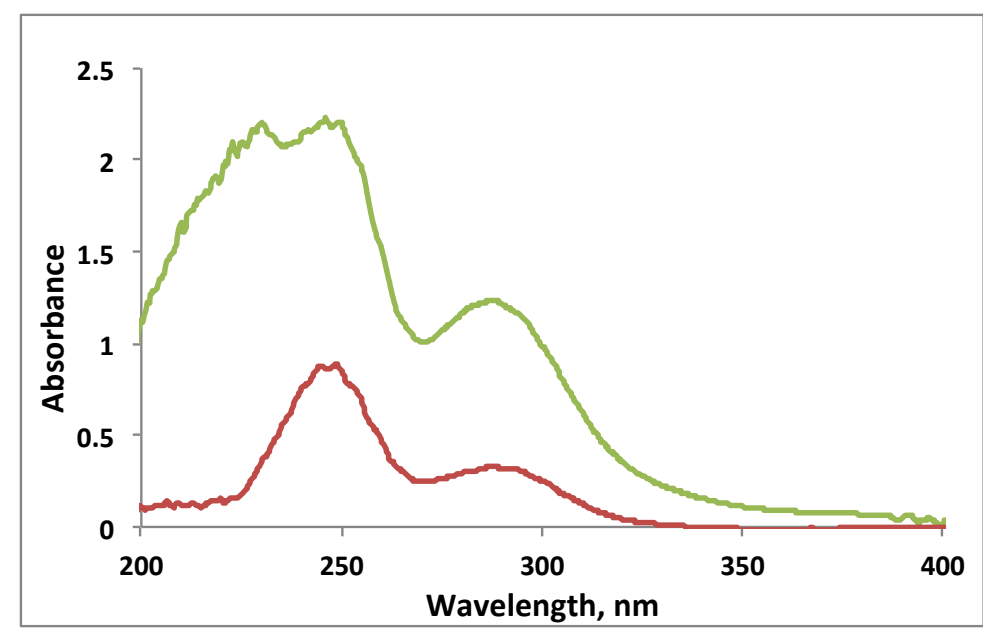

Figure 16: Comparison of aqueous $\mathrm{KTcO}_{4}$ solution UV spectra in the carbonate buffer (red trace) and in $\mathrm{Na}_{2} \mathrm{CO}_{3} / \mathrm{NaBH}_{4}$ mixture (green trace) prior to reaction start

The reaction mixture was slowly heated to about $75-80^{\circ} \mathrm{C}$ and was kept at this temperature for about 4 hours. Aliquots were periodically removed and subjected to UV analysis. No reduction of Tc(VII) to $\mathrm{Tc}(\mathrm{I})$ was observed as evident from the UV spectra remaining unchanged throughout.

Further literature examination revealed that the addition of a stabilizing agent to the reaction mixture is suggested [Alberto et al., 1998(2)]. The stabilizing agent is a chelating ligand (Ligand, Eq. 12), presumably incorporated into the coordination framework of the reduced technetium. In the literature, the preferred stabilizing agent is tartrate, whose addition to the reaction mixture is suggested to be in such an amount that its concentration is higher than that of $\mathrm{TcO}_{4}{ }^{-}$to be reduced.

Following this methodology, solid $\mathrm{Na}_{2} \mathrm{CO}_{3}(0.4 \mathrm{~g}, 3.8 \mathrm{mmol}), \mathrm{NaBH}_{4}(0.5 \mathrm{~g}, 13 \mathrm{mmol})$, and $\left(\mathrm{K}_{2}\right)$ Tartrate $(0.5 \mathrm{~g}, 2.2 \mathrm{mmol})$ salts were mixed, the system flushed with $\mathrm{CO}$ for 1 hour, and this mixture added to the unreacted mix generated during the first synthesis. A control UV spectrum was acquired to verify that addition of tartrate did not introduce any spectral interference. The reaction mixture was slowly heated to about $75-80^{\circ} \mathrm{C}$ and then kept at this temperature. After about 45 minutes, the reaction solution turned from colorless to pink and changes in the UV spectrum were observed consistent with the partial reduction of Tc(VII). Rard, 1983, has suggested that the pink color corresponds to an unstable $\mathrm{TcO}_{4}{ }^{3-}$ intermediate species formed during the alkaline reduction of $\mathrm{TcO}_{4}^{-}$. The spectrum undergoes further changes for up to 3 hours of reaction time (Figure 17, left). At this time, the pink color of the reaction solution turned back to colorless, indicating the disappearance of the intermediate technetium species. From this point forward, the UV spectrum remained unchanged and the reaction mixture was cooled to room temperature.

The main spectral changes observed during the reduction reaction included the disappearance of the $\mathrm{TcO}_{4}$ bands at 248 and $288 \mathrm{~nm}$ and appearance of the new bands at about $230 \mathrm{~nm}$ and $278-282 \mathrm{~nm}$, which are attributed to the $\mathrm{Tc}(\mathrm{CO})_{3}{ }^{+}$species. The exact maximum position of these bands may differ because of potential overlap of these spectral bands with any unreacted $\mathrm{TcO}_{4}{ }^{-}$and/or $\mathrm{NaBH}_{4}$ remaining in the reaction mixture. In addition, the very high absorbance in the $200-260 \mathrm{~nm}$ region can lead to detector saturation and prevent a careful analysis of the spectral information. Since the literature lacks any 
description of the UV spectrum of any technetium(I) tricarbonyl species, this assignment should be verified in the future by additional structural characterization.

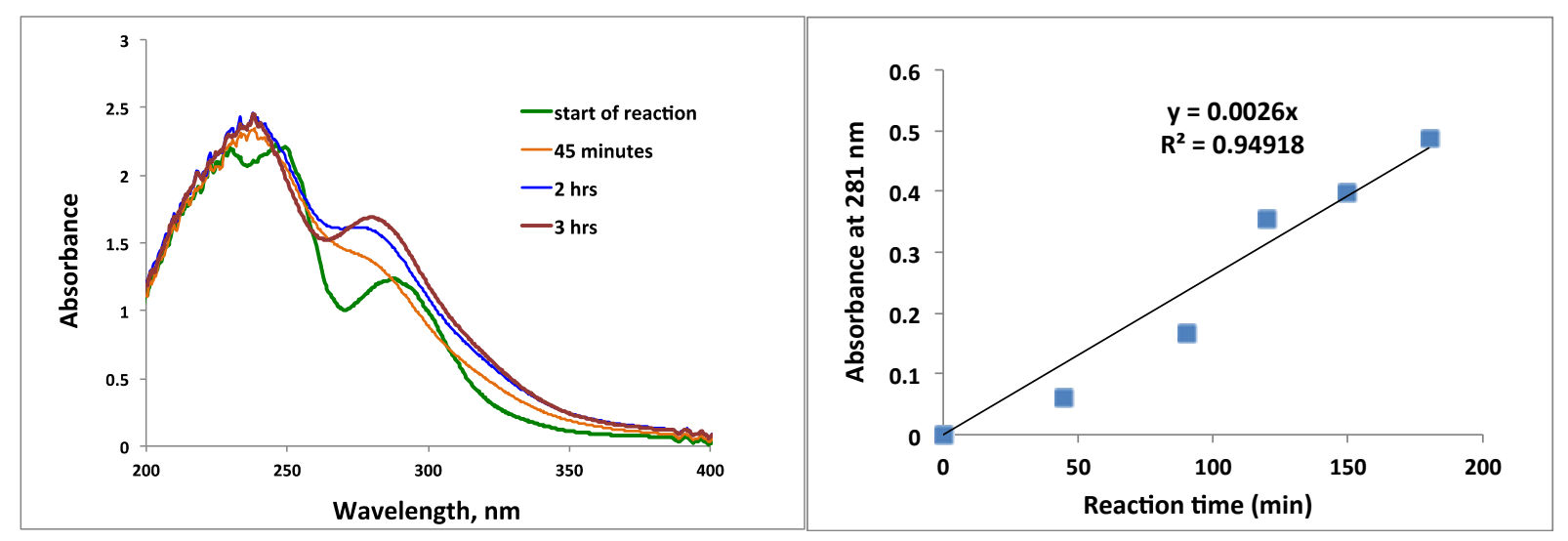

Figure 17: Monitoring of the $\mathrm{TcO}_{4}{ }^{-}$reduction by the UV spectroscopy

The absorbance value at $281 \mathrm{~nm}$, measured prior to the start of the reaction, was subtracted from the absorbance at this location at various reaction time points. The obtained values were plotted against reaction time and a nearly linear dependence of the $281 \mathrm{~nm}$ absorbance versus time was observed (Figure 17, right). This result suggests that the kinetic behavior of the $\mathrm{TcO}_{4}{ }^{-}$reduction observed in this study using an analytical quantity of $\mathrm{TcO}_{4}{ }^{-}$is slower than that reported when trace amounts of pertechnetate are used [Alberto et al., 1998, 1998(2)]. Because of the overlapping nature of the $\mathrm{TcO}_{4}{ }^{-}$and $\mathrm{Tc}(\mathrm{CO})_{3}{ }^{+}$ spectra, any calculation of the reaction yield by UV-vis spectroscopy alone is difficult.

\subsection{Characterization of the Reaction Product}

The reaction described above was completed on Friday 10/05/2012 and the reaction mixture was left in the reaction vessel over the weekend. On Monday 10/08/2012, the reaction mixture again was examined by UV spectroscopy. Figure 18 compares the UV spectra of the reaction mixture collected immediately after reaction completion on 10/05/2012 (red trace) with that obtained 3 days later on 10/08/2012 (blue trace). The absorbance at $279.2 \mathrm{~nm}$ has shifted to $282.9 \mathrm{~nm}$. Because of the lack of appearance of the $248 \mathrm{~nm}$ band characteristic for $\mathrm{TcO}_{4}{ }^{-}$, this spectral change is not consistent with reoxidation of the $\mathrm{Tc}(\mathrm{CO})_{3}{ }^{+}$product back to $\mathrm{TcO}_{4}{ }^{-}$. No other significant spectral changes were observed. Nevertheless, it was decided to purify the reaction mixture by removing any $\mathrm{TcO}_{4}{ }^{-}$potentially present.

Pertechnetate can be separated from most anions by passing the reaction mixture through an appropriate anion-ion exchange resin bed. For these pertechnetate separation experiments, the reaction mixture was divided into four subsamples. The first subsample was kept without any further treatment as a control. The second subsample was subjected to an acid swing induced by addition of $\mathrm{HCl}$ to a $\mathrm{pH}$ of 1 (red). The function of this acidification is to destroy reducing agent $\mathrm{NaBH}_{4}$ and convert it to redox-inactive boric acid. The acidified solution (blue) was then returned to the alkaline $\mathrm{pH}$ by addition of solid $\mathrm{Na}_{2} \mathrm{CO}_{3}$. The third and fourth subsamples of the reaction mixture were passed through a Purolite A850 ion exchange column $(2 \mathrm{~mL})$. Purolite A850 resin is selective for large weakly hydrated anions such as perchlorate (Levitskaia et al. 2007) and is expected to perform similarly toward $\mathrm{TcO}_{4}^{-}$. After passing through the 
column, the third reaction mixture subsample was kept without further treatment while the fourth one (yellow) was subjected to the acid/base swing as described above.

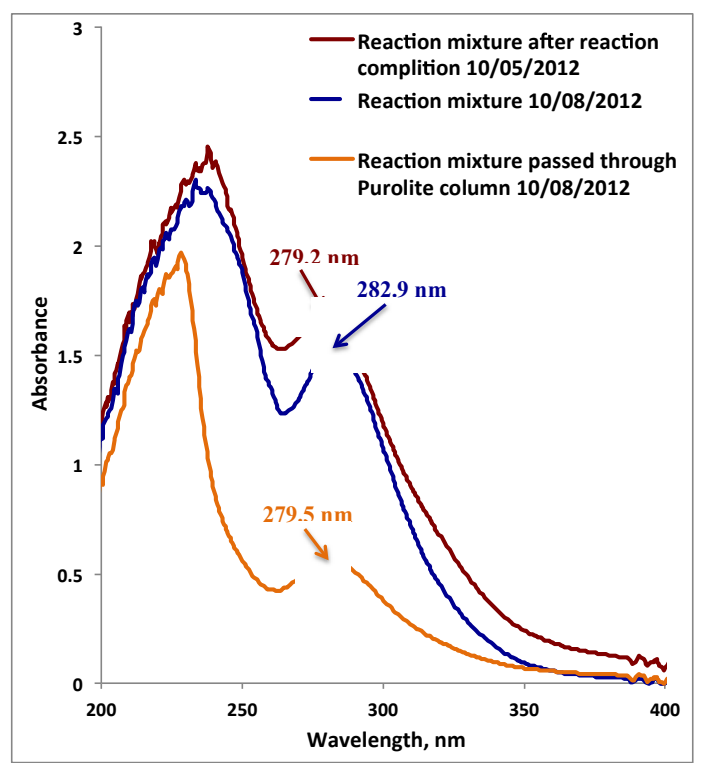

Figure 18: Comparison of UV spectra of reaction mixture. Samples collected on 10/05/2012 right after reaction completion (red), 10/08/2012 subjected to treatment (blue), and 10/08/2012 after Purolite A850 purification (yellow).

Figure 18 compares UV spectra collected on 10/08/2012 corresponding to the reaction mixture subsamples collected before and after ion exchange treatment. It was found that the $282.9 \mathrm{~nm}$ band has undergone a blue shift to $279.5 \mathrm{~nm}$, nearly identical to that observed for the initial reaction mixture right after reaction completion on $10 / 05 / 2012$. Based on these observations, it is concluded that the main product of the $\mathrm{TcO}_{4}{ }^{-}$reduction reaction is the Tc(I) tricarbonyl triaqua complex $\left[\mathrm{Tc}(\mathrm{CO})_{3}{ }^{+} \cdot\left(\mathrm{H}_{2} \mathrm{O}\right)_{3}\right]^{+}$. With time, the tartrate anion exchanges with the Tc(I) water ligands in accord with the reaction noted in Eq. 13 resulting in the red shift of the $279.2 \mathrm{~nm}$ band (Figure 18, red and blue traces).

$$
\left[\mathrm{Tc}(\mathrm{CO})_{3}{ }^{+} \cdot\left(\mathrm{H}_{2} \mathrm{O}\right)_{3}\right]^{+}+\operatorname{Tartrate}^{2-} \Leftrightarrow\left[\mathrm{Tc}(\mathrm{CO})_{3}{ }^{+} \cdot\left(\mathrm{H}_{2} \mathrm{O}\right)_{\mathrm{m}} \cdot \text { Tartrate }^{2-}\right]^{-}+(3-\mathrm{m}) \mathrm{H}_{2} \mathrm{O}
$$

This ion-exchange treatment also removed the negatively charged $\left[\mathrm{Tc}(\mathrm{CO})_{3}{ }^{+} \cdot\left(\mathrm{H}_{2} \mathrm{O}\right)_{\mathrm{m}} \cdot \mathrm{Tartrate}^{2-}\right]^{-}$complex ion leaving the positively charged $\left[\mathrm{Tc}(\mathrm{CO})_{3}{ }^{+} \cdot\left(\mathrm{H}_{2} \mathrm{O}\right)_{3}\right]^{+}$species in the eluted reaction mixture and blueshifting the $282.9 \mathrm{~nm}$ band to its original location in the UV-vis spectrum.

To support this hypothesis, UV spectra corresponding to the acidified-to-pH 1 subsamples of the reaction mixture with and without Purolite A850 pretreatment were acquired (Figure 19, left). The spectral profiles were found to be nearly identical, with the high energy maximum located at about $224 \mathrm{~nm}$ and the lower energy maximum located at $275 \mathrm{~nm}$. The exact location of the high energy UV band is difficult to establish due to the very high absorbance in this region.

It is proposed that the acidification of the reaction mixture resulted in protonation of the tartrate forming tartaric acid and conversion of the $\left[\mathrm{Tc}(\mathrm{CO})_{3}{ }^{+} \cdot\left(\mathrm{H}_{2} \mathrm{O}\right)_{\mathrm{m}} \cdot \text { Tartrate }^{2-}\right]^{-}$complex to $\left[\mathrm{Tc}(\mathrm{CO})_{3}{ }^{+} \cdot\left(\mathrm{H}_{2} \mathrm{O}\right)_{3}\right]^{+}$via the 
reaction shown in Eq. 14. This result confirmed our previous hypothesis on the slow kinetics of reaction 3 under alkaline conditions.

$$
\left[\mathrm{Tc}(\mathrm{CO})_{3}{ }^{+} \cdot\left(\mathrm{H}_{2} \mathrm{O}\right)_{\mathrm{m}} \cdot \text { Tartrate }^{2-}\right]^{-}+2 \mathrm{H}_{3} \mathrm{O}^{+} \Leftrightarrow\left[\mathrm{Tc}(\mathrm{CO})_{3}{ }^{+} \cdot\left(\mathrm{H}_{2} \mathrm{O}\right)_{3}\right]^{+}+\mathrm{H}_{2} \text { Tartrate }+(\mathrm{m}-1) \mathrm{H}_{2} \mathrm{O} \quad \text { Eq. } 14
$$

The second conclusion is drawn from the result that the acidified subsamples with and without ionexchange pretreatment have nearly identical profiles. This implies that only negligible (and undetected by UV spectroscopy) amounts of $\mathrm{TcO}_{4}{ }^{-}$are present in the reaction mixture. The reasoning for this conclusion includes two considerations: a) ion-exchange resin is expected to remove $\mathrm{TcO}_{4}{ }^{-}$anion from one subsample and $b$ ) acidification of the reaction mixture not subjected to ion exchange would have no effect on the spectral profile (previously reported to be $\mathrm{pH}$-independent (Rulfs et al., 1967)). These effects would lead to the significantly different UV spectra of the acidified subsamples with and without ion-exchange pretreatment if substantial quantities of pertechnetate remained.

On the other hand, the spectra for both species are very similar (Figure 19, left). This interpretation is additionally supported by the low intensity in the $250 \mathrm{~nm}$ region that is positioned between two major spectral bands observed. This location corresponds to the intense $\mathrm{TcO}_{4}{ }^{-}$band at $248 \mathrm{~nm}$, and low absorbance at this region indicates that no or a very low amount of $\mathrm{TcO}_{4}{ }^{-}$is present in both acidified subsamples, i.e., regardless of the whether any ion-exchange treatment was performed. Overall these observations suggest a nearly quantitative yield of the $\mathrm{TcO}_{4}{ }^{-}$reduction to $\mathrm{Tc}(\mathrm{CO})_{3}{ }^{+}$, consistent with literature reports with more technetium dilute solutions.

Completion of the full acid/base cycle, and returning both acidified subsamples to the alkaline $\mathrm{pH}$ of 11 by addition of solid $\mathrm{Na}_{2} \mathrm{CO}_{3}$, resulted in the red shift of the $275-\mathrm{nm}$ band and regeneration of the spectral profiles very similar to the one observed for the reaction mixture subjected to no further treatment (Figure 19, right). This observation is consistent with the conclusion about the formation of the $\left[\mathrm{Tc}(\mathrm{CO})_{3}{ }^{+} \cdot\left(\mathrm{H}_{2} \mathrm{O}\right)_{\mathrm{m}} \cdot \text { Tartrate }^{2-}\right]^{-}$complex under alkaline conditions via the reaction shown in Eq. 13 . The narrowing and blue shifting of the high-energy UV band after the acid/base swing was attributed to acid decomposition of borohydride and formation of optically transparent borate. 

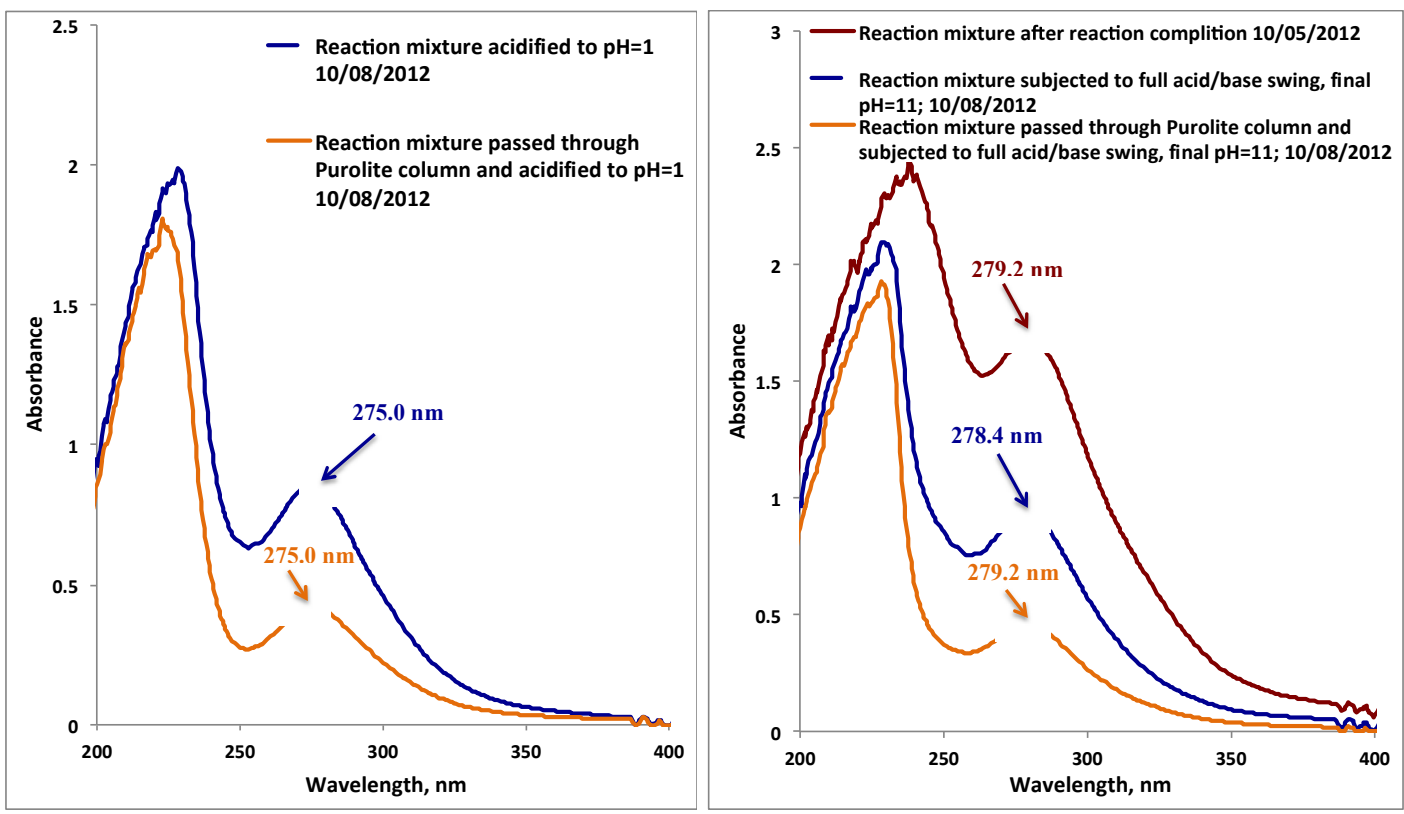

Figure 19: UV Spectra of reaction mixture

$U V$ spectra of the reaction mixture (1) acidified to $\mathrm{pH}=1$ (left) and returned to $\mathrm{pH}=11$ after full acid/base swing (right) with and without Purolite A850 pretreatment. UV spectrum of the reaction mixture collected after reaction completion is included in the right panel for comparison.

On 10/11/2012, in an attempt to determine the amount of technetium retained on the ion-exchange resin, the column was initially stripped using carbonate buffer at $\mathrm{pH} 11$. The eluent was collected in fractions and analyzed by UV spectroscopy. It was found that the reaction product $\mathrm{Tc}(\mathrm{CO})_{3}{ }^{+}$was eluted using this carbonate eluent. The retention of $\mathrm{Tc}(\mathrm{CO})_{3}{ }^{+}$on the ion-exchange resin additionally supports the proposed formation of the negatively charged complex ion $\left[\mathrm{Tc}(\mathrm{CO})_{3}{ }^{+} \cdot\left(\mathrm{H}_{2} \mathrm{O}\right)_{\mathrm{m}} \cdot \text { Tartrate }^{2-}\right]^{-}$. The $\mathrm{pH}$ of the carbonate eluent was adjusted to 13 by addition of $\mathrm{NaOH}$ solution; however, complete stripping of technetium from the column could not be achieved.

To determine the amount of technetium remaining on the ion-exchange resin, a weighed amount of the ion-exchange resin was removed from the column and reacted with concentrated $\mathrm{HNO}_{3}$; destroying the quaternary amine functional groups and releasing all bound technetium back into the solution. An aliquot of the stripping solution first was diluted with water. Then all stripping solutions were subjected to ${ }^{99} \mathrm{Tc}$ analysis by liquid scintillation counting. The technetium recovery was found to be about $80 \%$. It was determined that about $75 \%$ of $\mathrm{Tc}(\mathrm{CO})_{3}{ }^{+}$as $\left[\mathrm{Tc}(\mathrm{CO})_{3}{ }^{+} \cdot\left(\mathrm{H}_{2} \mathrm{O}\right)_{\mathrm{m}} \cdot \text { Tartrate }^{2-}\right]^{-}$was retained by the ionexchange column.

\subsection{Monitoring Stability of the $\mathrm{Tc}(\mathrm{CO})_{3}{ }^{+}$Product}

To estimate the stability of the $\mathrm{Tc}(\mathrm{CO})_{3}{ }^{+}$product, three subsamples were monitored by UV spectroscopy, including the unmodified reaction mixture and the reaction mixture subjected to the acid/base swing with and without ion-exchange pretreatment. The results are shown in Figure 20. 

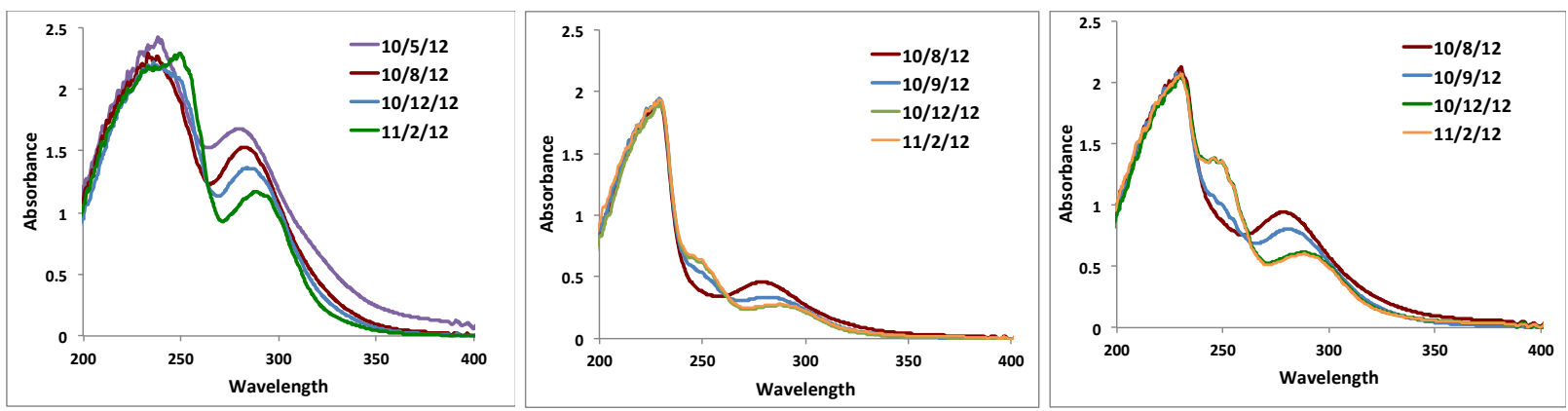

Figure 20: Time-dependent UV spectra of unmodified reaction mixture (left) and the reaction subjected to acid/base wwing with (center) and without (right) ion exchange pretreatment

It was observed that the $\mathrm{Tc}(\mathrm{CO})_{3}{ }^{+}$product has only limited stability and that it quickly oxidized back to $\mathrm{TcO}_{4}{ }^{-}$. This process was rapid and complete within 4 days in the absence of the borohydride reductant (Figure 20, center and right). In the presence of the reductant, the oxidation of $\mathrm{Tc}(\mathrm{CO})_{3}{ }^{+}$to $\mathrm{TcO}_{4}{ }^{-}$was slowed down only slightly (Figure 20, left).

\subsection{Summary}

The experimental study led to several important conclusions summarized below.

- The molar absorptivities of $\mathrm{TcO}_{4}{ }^{-}$in the carbonate buffer were established for the $248 \mathrm{~nm}$ and $288 \mathrm{~nm}$ bands as $5600 \mathrm{M}^{-1} \mathrm{~cm}^{-1}$ and $2200 \mathrm{M}^{-1} \mathrm{~cm}^{-1}$, respectively, in reasonable agreement with prior literature assignments

- UV spectroscopy can be used to monitor reduction of $\mathrm{TcO}_{4}{ }^{-}$

- It was established that $\mathrm{CO}$ flushing of the solid mixture of $\mathrm{Na}_{2} \mathrm{CO}_{3}$ and $\mathrm{NaBH}_{4}$ prior to addition of aqueous $\mathrm{TcO}_{4}{ }^{-}$solution is the critical step for the reduction reaction

- There appears to be a need for a stabilizing chelating agent during the $\mathrm{TcO}_{4}{ }^{-}$reduction, but this conclusion requires further testing

- Reductive carbonylation of $\mathrm{TcO}_{4}{ }^{-}$to $\mathrm{Tc}(\mathrm{CO})_{3}{ }^{+}$was achieved; based on the $\mathrm{UV}$ analysis of the reaction mixture, it is concluded that this conversion is nearly quantitative

- The reaction product appears to exist in two forms, including $\left[\mathrm{Tc}(\mathrm{CO})_{3}{ }^{+} \cdot\left(\mathrm{H}_{2} \mathrm{O}\right)_{3}\right]^{+}$and $\left[\mathrm{Tc}(\mathrm{CO})_{3}{ }^{+} \cdot\left(\mathrm{H}_{2} \mathrm{O}\right)_{\mathrm{m}} \bullet\right.$ Tartrate $\left.^{2-}\right]$. The equilibrium between these two forms depends on the solution $\mathrm{pH}$. In acidic solution, tartaric acid is formed, resulting in a shift of the equilibrium toward the $\left[\mathrm{Tc}(\mathrm{CO})_{3}{ }^{+} \cdot\left(\mathrm{H}_{2} \mathrm{O}\right)_{3}\right]^{+}$complex. Alkaline conditions favor formation of the $\left[\mathrm{Tc}(\mathrm{CO})_{3}{ }^{+} \cdot\left(\mathrm{H}_{2} \mathrm{O}\right)_{\mathrm{m}} \cdot \operatorname{Tartrate}^{2-}\right]^{-}$ complex.

- $\left[\mathrm{Tc}(\mathrm{CO})_{3}{ }^{+} \cdot \mathrm{H}_{2} \mathrm{O} \cdot \text { Tartrate }^{2-}\right]^{-}$product $(75 \%$ of total technetium in the reaction mixture) was retained by Purolite A850 ion exchange resin

- Eighty percent post ion-exchange recovery of ${ }^{99} \mathrm{Tc}$ was attained, according to liquid scintillation counting

- It was observed that $\mathrm{Tc}(\mathrm{CO})_{3}{ }^{+}$species are unstable and quickly oxidize to $\mathrm{TcO}_{4}{ }^{-}$.

Further studies are warranted to support these conclusions and optimize the synthetic procedure for the reduction of $\mathrm{TcO}_{4}{ }^{-}$to $\mathrm{Tc}(\mathrm{CO})_{3}{ }^{+}$. 


\subsection{Summary and Conclusions}

In this report, we attempted to develop a correlation between measured data for the Hanford waste tank supernatants and the amount of alkaline supernatant-soluble technetium that, based on earlier studies, was determined to not be present as pertechnetate. This report starts with a brief review of the relevant background, in which a large number of variables to be considered is described. However, the best correlation appears to be an inverse correlation of the fraction of $n-T c$ present in the supernatant with the ${ }^{137} \mathrm{Cs}$ concentration of the supernatant.

These results naturally lead to the next section, which contains an examination of the effects of water radiolysis in the inorganic compound-only based environment of the Hanford tank supernatants. It should be noted that this investigation relies on actual tank analytical data together with a model that incorporates all relevant inorganic chemistry related rate constants. These calculations deal only with the rate of pertechnetate reduction; it must be noted that technetium can reduce to technetium dioxide and predominantly report to the sludge or form a soluble $\mathrm{Tc}(\mathrm{I})$ compound and remain in solution.

From this study it was determined that, for the timescales associated with the existence of the Hanford tank supernatants, the rates of radiolysis produce sufficient concentrations of reducing species so that the bulk of the technetium should not be present as pertechnetate for any Hanford tank. However, this is contrary to observations and so implies that reoxidation of the reduced technetium plays a key role.

Based on the studies to date, a speculative minimalist hypothesis can be presented concerning the fate of technetium in the Hanford tanks. A schematic summarizing the hypothesis is shown in Figure 21.

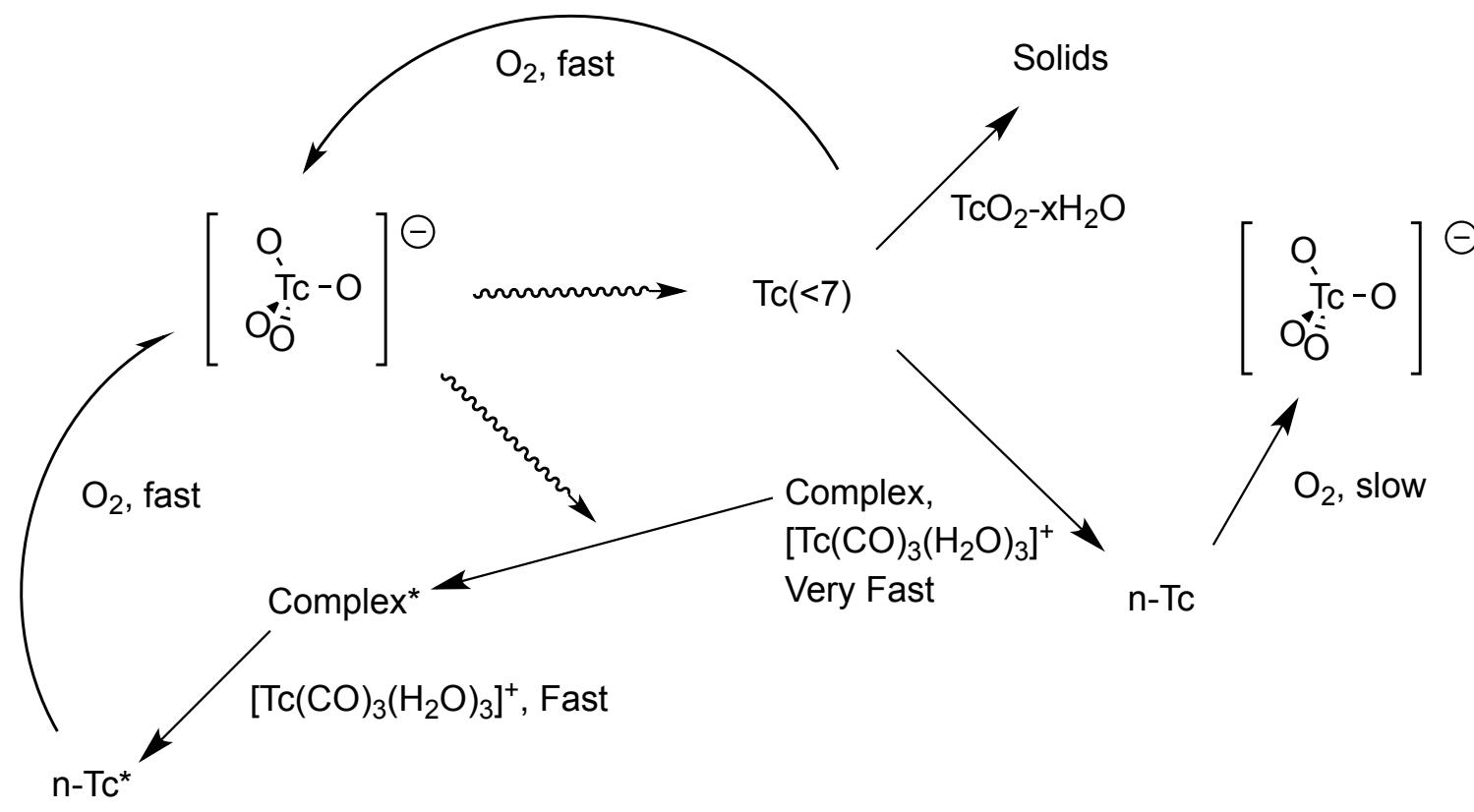

where $n-T c^{*}=T c(I)$ tricarbonyl species with exchangable ligands $\mathrm{n}-\mathrm{Tc}=\mathrm{Tc}(\mathrm{I})$ tricarbonyl species with non-exchangable ligands

Figure 21: Minimalist schematic of Hanford tank technetium chemistry 
The reaction sequence starts with pertechnetate, $\mathrm{Tc}(\mathrm{VII})$. Radiolysis of the aqueous solution reduces the $\mathrm{Tc}(\mathrm{VII})$ to technetium in a lower $(<7)$ oxidation state. If no suitable chemical species (reductants and carbon monoxide) are present, then poorly soluble technetium dioxide, Tc(IV), is formed and reports mainly to the sludge, although if air is present, reoxidation back to pertechnetate should occur.

Alternatively, if suitable reagents are present, formation of $\left[\mathrm{Tc}(\mathrm{CO})_{3}\left(\mathrm{H}_{2} \mathrm{O}\right)_{3}\right]^{+}$can occur. But this $\mathrm{Tc}(\mathrm{I})$ species, as documented in the published literature and verified by work described in Section 4.0, only has a relatively short lifetime in aerated, alkaline solution. To form a relatively stable compound in the conditions found in Hanford tank supernatants, further chemistry must occur.

It is hypothesized that rapidly exchangeable coordination sites to the $\mathrm{Tc}(\mathrm{I})$ atom are key for any reoxidation to occur. The three water molecules bound to $\mathrm{Tc}(\mathrm{I})$ in $\left[\mathrm{Tc}(\mathrm{CO})_{3}\left(\mathrm{H}_{2} \mathrm{O}\right)_{3}\right]^{+}$are known to be rapidly exchangeable with solution water molecules and exchange much more rapidly than do the carbon monoxide ligands (Helm, 2008). So if a suitable (likely tridentate) molecule such as gluconate or perhaps aminocarboxylates are present (and are represented above as "complex"), the rapidly exchangeable ligand sites are blocked and reoxidation of this n-Tc species occurs slowly, as has been reported previously.

However, radiolysis will also affect these multidentate organic molecules to make simpler but less effective molecules that still might displace the water molecules. These types of molecules (indicated above as "complex, ${ }^{*}$ " will form but reoxidize more rapidly back to pertechnetate than any Tc(I) species lacking exchangeable coordination sites.

So the effect of radiation works in two ways. First, radiolysis will affect water, forming products that can reduce pertechnetate. On the timescale of the Hanford tank supernatants, this process should have reduced all pertechnetate present. So reoxidation (presumably, but not necessarily, by reaction with oxygen) competes with reduction of pertechnetate by radiolysis. Second, under the right conditions, formation of $\mathrm{Tc}(\mathrm{I})$ tricarbonyl species is possible. If suitable organic compounds are present, then $\mathrm{Tc}(\mathrm{I})$ species are slow to reoxidize and can build up in the aqueous phase.

Therefore, aqueous radiolysis tends to reduce pertechnetate. Reaction with complex organic molecules may also form species (hydrogen and carbon monoxide) that form soluble, lower-valence technetium compounds. However, radiolysis also can scrub the aqueous phase of those organic molecules needed to keep low valent technetium from reoxidizing to pertechnetate by contact with air.

This analysis suggests that supernatants with relatively large amounts of complex organic molecules but only moderate amounts of radiolysis would likely have the largest fraction of n-Tc. Note that this comment assumes equal rates of access to oxygen from air, an assumption that is unlikely to be true. However, a multivariable analysis of radiolysis with other variables such as dose may prove fruitful to support or refute this hypothesis, and is recommended as a part of any future related study.

This hypothesis does explain why such tanks as AN-102, AN-107, SY-103 and SY-101 (high in complex organic molecules, relatively low tank supernatant dose as approximated by ${ }^{137} \mathrm{Cs}$ activity) are high in nTc but also why AZ-101 and AZ-102 essentially lack any n-Tc (low amounts of complex organic molecules and very high relative supernatant tank doses as represented by ${ }^{137} \mathrm{Cs}$ activity). More detailed analysis is not possible because of a lack of extensive tank knowledge as to organic compound speciation as well as a lack of knowledge as to how differing organic complexants bound to the Tc-tricarbonyl moiety impact the rate of reoxidation in air. 
As a final note, there currently exists no information as to which form of technetium (insoluble technetium dioxide, soluble pertechnetate, or soluble $\mathrm{n}-\mathrm{Tc}$ ) is present in the Hanford tank saltcakes and may represent a significant source of additional alkaline-soluble, $n-T c$. Therefore, discovering the technetium speciation in saltcake seems prudent. Additional technetium speciation identification via spectroscopic methods such as ${ }^{99} \mathrm{Tc}$ NMR would add to the database of information used to obtain the solution non-pertechnetate/pertechnetate ratios and add confidence to the correlation's validity.

In conclusion, the primary goal was to see if a technically defensible, chemistry-based approach was available to correlate existing tank characterization data to the amount of alkaline supernatant soluble technetium. This goal was not achieved. Two major obstacles are: 1) variability of the values for analytes in the measurements and 2) the likely complexity of the chemistry associated with the formation and stability of the alkaline-supernatant soluble n-Tc species. However, this work does provide some indicators as to which Hanford tanks might prove interesting to sample in additional quests to ascertain the ratio of soluble n-Tc versus pertechnetate in Hanford tank supernatants. 


\subsection{References}

Alberto, R, K Ortner, N Wheatley, R Schibli, and AP Schubiger. 2001. "Synthesis and Properties of Boranocarbonate: A Convenient in Situ CO Source for the Aqueous Preparation of $\left[{ }^{99 \mathrm{~m}} \mathrm{Tc}\left(\mathrm{OH}_{2}\right)_{3}(\mathrm{CO})_{3}\right]^{+} . "$ Journal of the American Chemical Society 123(13):3135-36. $10.1021 / \mathrm{ja} 003932 \mathrm{~b}$.

Alberto, R, R Schibli, A Egli, P August Schubiger, WA Herrmann, G Artus, U Abram, and TA Kaden. 1995. "Metal Carbonyl Syntheses XXII. Low Pressure Carbonylation of $\left[\mathrm{MOCl}_{4}\right]-$ and $\left[\mathrm{MO}_{4}\right]$ : The Technetium(I) and Rhenium(I) Complexes $\left[\mathrm{NEt}_{4}\right]_{2}\left[\mathrm{MCl}_{3}(\mathrm{CO})_{3}\right]$." Journal of Organometallic Chemistry 493(1-2):119-27. 10.1016/0022-328x(94)05373-j.

Alberto, R, R Schibli, A Egli, AP Schubiger, U Abram, and TA Kaden. 1998. "A Novel Organometallic Aqua Complex of Technetium for the Labeling of Biomolecules: Synthesis of $\left.{ }^{99 \mathrm{~m}} \mathrm{Tc}\left(\mathrm{OH}_{2}\right)_{3}(\mathrm{CO})_{3}\right]^{+}$from $\left[{ }^{99 \mathrm{~m}} \mathrm{TcO}_{4}\right]^{-}$in Aqueous Solution and Its Reaction with a Bifunctional Ligand." Journal of the American Chemical Society 120(31):7987-88. 10.1021/ja980745t.

Ben-Said, K, Y Seimbille, M Fattahi, C Houee-Lévin, and JC Abbé. 2001. "Gamma Radiation Effects on Potassium Pertechnetate in Carbonate Media." Applied Radiation and Isotopes 54(1):45-51. 10.1016/s0969-8043(00)00162-7.

Bernard, JG, E Bauer, MP Richards, JB Arterburn, and RM Chamberlin. 2001. "Catalytic Reduction of Pertechnetate $\left({ }^{99} \mathrm{TcO}_{4}{ }^{-}\right)$in Simulated Alkaline Nuclear Wastes." Radiochimica Acta 89(1):59-61. 10.1524/ract.2001.89.1.059.

Berning, DE, NC Schroeder, and RM Chamberlin. 2005. "The Autoreduction of Pertechnetate in Aqueous, Alkaline Solutions." Journal of Radioanalytical and Nuclear Chemistry 263(3):613-18. 10.1007/s10967-005-0632-x.

Blanchard Jr., DL, GN Brown, SD Conradson, SK Fadeff, GR Golcar, NJ Hess, GS Klinger, and DE Kurath. 1997. Technetium in Alkaline, High-Salt, Radioactive Tank Waste Supernate: Preliminary Characterization and Removal. Report No. PNNL-11386, Pacific Northwest National Laboratory, Richland, Washington.

Blanchard Jr., DL, DE Kurath, and JR Bontha. 2000a. Small Column Testing of Superlig 639® for Removal of ${ }^{99}$ Tc from Hanford Tank Waste Envelope A (Tank 241-AW-101). Report No. PNWD3004, Battelle-Pacific Northwest Division, Richland, WA.

Blanchard Jr., DL, DE Kurath, GR Golcar, and SD Conradson. 1996. Technetium Removal Column Flow Testing with Alkaline, High Salt, Radioactive Tank Waste. Report No. PNNL-11398, Pacific Northwest National Laboratory, Richland, WA.

Blanchard Jr., DL, DE Kurath, and BM Rapko. 2000b. Small Column Testing of Superlig ${ }^{\circledR} 639$ for Removal of ${ }^{99}$ Tc from Hanford Tank Waste Envelope C (Tank 241-AN-107). Report No. PNWD3028, Battelle-Pacific Northwest Division, Richland, WA. 
Boggs, MA, W Dong, B Gu, and NA Wall. 2010. "Complexation of Tc(IV) with Acetate at Varying Ionic Strengths." Radiochimica Acta 98(9-11):583-87. 10.1524/ract.2010.1757.

Burgeson, IE, DL Blanchard Jr., and JR Deschane. 2004a. Small Column Testing of Superlig ${ }^{\circledR} 639$ for Removing 99Tc from Hanford Tank Waste 241-AN-102 Supernate (Envelope C) Mixed with Tank 241-C-104 Solids (Envelope D) Wash and Permeate Solutions. Report No. PNWD-3252, Rev. 1, Battelle, Pacific Northwest Division, Richland, Washington.

Burgeson, IE, DL Blanchard Jr., and JR Deschane. 2002. Small Column Testing of Superlig ${ }^{\circledR} 639$ for Removing ${ }^{99}$ Tc from Hanford Tank Waste Envelope A (Tank 241-AP-101). Report No. PNWD3222, Battelle - Pacific Northwest Division, Richland, WA.

Burgeson, IE, DL Blanchard Jr., and JR Deschane. 2004b. Small Column Testing of Superlig ${ }^{\circledR} 639$ for Removing ${ }^{99}$ Tc from Hanford Tank Waste Envelope B (Tank 241-AZ-101). Report No. PNWD3281, Battelle - Pacific Northwest Division, Richland, WA.

Burgeson, IE, JR Deschane, and DL Blanchard. 2005. "Removal of Technetium from Hanford Tank Waste Supernates." Separation Science and Technology 40(1-3):201-23. 10.1081/ss-200041916.

Deutsch, E, WR Heineman, R Hurst, JC Sullivan, WA Mulac, and S Gordon. 1978. "Production, Detection, and Characterization of Transient Hexavalent Technetium in Aqueous Alkaline Media by Pulse Radiolysis and Very Fast Scan Cyclic Voltammetry " J. Chem. Soc., Chem. Commun. (23):1038-40. DOI: 10.1039/C39780001038

Egorov, OB, MJ O'Hara, and JW Grate. 2012. "Automated Radioanalytical System Incorporating Microwave-Assisted Sample Preparation, Chemical Separation, and Online Radiometric Detection for the Monitoring of Total ${ }^{99}$ Tc in Nuclear Waste Processing Streams." Analytical Chemistry 84(7):3090-98. 10.1021/ac300418b.

Egorov, OB, MJ O'Hara, and JW Grate. 2004. "Microwave-Assisted Sample Treatment in a Fully Automated Flow-Based Instrument: Oxidation of Reduced Technetiurn Species in the Analysis of Total Technetium-99 in Caustic, Aged Nuclear Waste Samples." Analytical Chemistry 76(14):3869-77. 10.1021/ac0497196.

Fessenden, RW, and D Meisel. 2000. "Addition of Oxide Radical Ions $\left(\mathrm{O}^{-}\right)$to Nitrite and Oxide Ions $\left(\mathrm{O}_{2}{ }^{-}\right)$ to Nitrogen Dioxide." J. Am. Chem. Soc. 122:3773-74.

Gu, BH, WM Dong, LY Liang, and NA Wall. 2011. "Dissolution of Technetium(IV) Oxide by Natural and Synthetic Organic Ligands under Both Reducing and Oxidizing Conditions." Environmental Science \& Technology 45(11):4771-77. 10.1021/es200110y.

Hassan, NM, K Adu-Wusu, CA Nash, and JC Marra. 2003. Multiple Ion Exchange Column Tests for Technetium Removal from Hanford Tank Waste Supernate (U). Report No. WSRC-MS-200300789, Westinghouse Savannah River Company, Aiken, South Carolina, 2003. 
Hassan, NM, WD King, DJ McCabe, and ML Crowder. 2001a. Small-Scale Ion Exchange Removal of Cesium and Technetium Form Envelope B Hanford Tank 241-AZ-102. Report No. WSRC-TR2000-00419, Rev 0, Westinghouse Savannah River Company, Aiken, South Carolina.

Hassan, NM, WD King, DJ McCabe, LL Hamm, and ME Johnson. 2001b. Superlig ${ }^{\circledR} 639$ Equilibrium Sorption Data for Technetium from Hanford Tank Waste Supernates. Report No. WSRC-MS2001-00573, Westinghouse Savannah River Company, Aiken, South Carolina.

Hassan, NM, DJ McCabe, and WD King. 2000a. Small-Scale Ion Exchange Removal of Cesium and Technetium from Hanford Tank 241-AN-103. Report No. BNF-003-98-0146, Rev. 1, Westinhouse Savanna River Company, Aiken, SC.

Hassan, NM, DJ McCabe, WD King, and ML Crowder. 2000b. Small-Scale Ion Exchange Removal of Cesium and Technetium from Hanford Tank 241-AN-102. Report No. BNF-003-98-0219, Westinghouse Savannah River Company, Aiken, SC.

Helm, L. 2008. "Ligand Exchange and Complex Formation Kinetics Studied by NMR Exemplified on Fac- $\left[(\mathrm{CO})(3) \mathrm{M}\left(\mathrm{H}_{2} \mathrm{O}\right)\right]^{+}(\mathrm{M}=\mathrm{Mn}, \mathrm{Tc}, \mathrm{Re}) . "$ Coordination Chemistry Reviews 252:2346-61.

Hess, NJ, Y Xia, and AR Felmy. 2006. "Solubility of $\mathrm{TcO}_{2 \mathrm{x}} \cdot \mathrm{H}_{2} \mathrm{O}(\mathrm{Am})$ in the Presence of Gluconate in Aqueous Solution." In Nuclear Waste Management, Vol 943, pp. 286-301. American Chemical Society.

King, WD, NM Hassan, and DJ McCabe. 2000. Intermediate-Scale Ion Exchange Removal of Cesium and Technetium from Hanford Tank 241-AN-102. Report No. WSRC-TR-2000-00420, Westinghouse Savannah River Company, Aiken, South Carolina.

King, WD, NM Hassan, DJ McCabe, LL Hamm, and ME Johnson. 2001. Technetium Removal from Hanford and Savannah River Site Actual Tank Waste Supernates with Superlig ${ }^{\circledR} 639$ Resin. Report No. WSRC-MS-2001-00760, Westinghouse Savannah River Co., Aiken, South Carolina.

Kissel, G, and SW Feldberg. 1969. "Disproportionation of the Technetate Ion in Aqueous Alkaline Media. An Electrochemical Study." The Journal of Physical Chemistry 73(9):3082-88. $10.1021 / \mathrm{j} 100843 \mathrm{a} 050$.

Kurath, DE, DL Blanchard Jr., and JR Bontha. 2000. Ion Exchange Distribution Coefficients for ${ }^{137}$ Cs and ${ }^{99}$ Tc Removal from Hanford Tank Supernatants AW-101 (Envelope A) and AN-107 (Envelope C). Report No. PNWD-2467, Battelle-Pacific Northwest Division, Richland, WA.

Levitskaia, TG, SI Sinkov, and SA Bryan. 2007. "In Situ Perchlorate Determination on Purolite A850 Ion Exchange Resin Via Raman Spectroscopy." Vibrational Spectroscopy 44(2):316-23. http://dx.doi.org/10.1016/j.vibspec.2007.02.002.

Lisbon, K, JC Sullivan, WA Mulac, S Gordon, and E Deutsch. 1989. "Pulse Radiolysis Studies on Pertechnetate and Perrhenate in Aqueous Media. Decay of the Technetium(IV) Transient." Inorg. Chem. 28:375-77. 
Lukens, WW, JJ Bucher, NM Edelstein, and DK Shuh. 2002. "Products of Pertechnetate Radiolysis in Highly Alkaline Solution: Structure of $\mathrm{TcO}_{2} \cdot \mathrm{H}_{2} \mathrm{O}$." Environmental Science \& Technology 36(5):1124-29. 10.1021/es015653+.

Lukens, WW, JJ Bucher, NM Edelstein, and DK Shuh. 2001. "Radiolysis of $\mathrm{TcO}_{4}{ }^{-}$in Alkaline, Nitrate Solutions: Reduction by $\mathrm{No}_{3}{ }^{2-}$." The Journal of Physical Chemistry A 105(41):9611-15. 10.1021/jp004534y.

Lukens, WW, DK Shu, NC Schroeder, and KR Ashley. 2006a. Behavior of Technetium in Alkaline Solution: Identification of the Non-Pertechnetate Species in High-Level Nuclear Waste Tanks at the Hanford Reservation. Presented at ACS Symposium Series 943, Quincy, IL, 16 pp. American Chemical Society, Washington, DC.

Lukens, WW, DK Shuh, NC Schroeder, and KR Ashley. 2006b. "Behavior of Technetium in Alkaline Solution: Identification of Non-Pertechnetate Species in High-Level Nuclear Waste Tanks at the Hanford Reservation." In Nuclear Waste Management, Vol 943, pp. 302-18. American Chemical Society.

Lukens, WW, DK Shuh, NC Schroeder, and KR Ashley. 2004. "Identification of the Non-Pertechnetate Species in Hanford Waste Tanks, Tc(I)-Carbonyl Complexes." Environmental Science \& Technology 38(1):229-33. 10.1021/es034318d.

McCabe, DJ, NM Hassan, WD King, JL Steimke, MA Norato, LL Hamm, LN Oji, and ME Johnson. 2000. Comprehensive Scale Testing of the Ion Exchange Removal of Cesium and Technetium from Hanford Tank Wastes. Report No. WSRC-MS-2000-00499, CH2MHill Hanford Group, Richland, WA.

Meisel, D, H Diamond, EP Horwitz, CD Jonah, MS Matheson, MC Sauer, Jr., JC Sullivan, F Barnabas, E Cerny, and YD Cheng. 1991. Radiolytic Generation of Gases from Synthetic Waste. Report No. ANL-91/41, Argonne National Laboratory, Argonne, Illinois.

Mincher, BJ, and SP Mezyk. 2009. "Radiation Chemical Effects on Radiochemistry: A Review of Examples Important to Nuclear Power." Radiochimica Acta 97(9):519-34. 10.1524/ract.2009.1646.

Schroeder, N, C., SD Radzinski, JR Ball, KR Ashley, SL Cobb, B Cutrell, JM Adams, C Johnson, and GD Whitener. 1995. Technetium Partioning for the Hanford Tank Waste Remediation System: Anion Exhcange Studies for Partioning Technetium from Synthetic DSSF and DSS Simulants and Actual Hanford Waste (101-SY and 103-SY) Using Reillex TM-HPQ Resin. Report No. LA-UR95-4440, Los Alamos National Laboratory, Los Alamos, NM.

Schroeder, NC, and KR Ashley. 2005. "Separation of Non-Pertechnetate Species from Hanford AN-107 Tank Waste." Journal of Radioanalytical and Nuclear Chemistry 263(3):567-73. 10.1007/s10967-005-0625-9. 
Schroeder, NC, SD Radzinski, KR Ashley, AP Truong, and PA Szczepaniak. 1998. Technetium Oxidation State Adjustment for Hanford Waste Processing. Science and Technology for Disposal of Radioactive Tank Wastes, Plenum Press, New York.

Schroeder, NC, SD Radzinski, KR Ashley, AP Truong, and GD Whitener. 2001. "Feed Adjustment Chemistry for Hanford 101-SY and 103-SY Tank Waste: Attempts to Oxidize the NonPertechnetate Species." Journal of Radioanalytical and Nuclear Chemistry 250(2):271-84. 10.1023/a:1017927109400.

Schweitzer, GK, and LL Pesterfield. 2010. The Aqueous Chemistry of the Elements. Oxford University Press, New York, NY.

Seifert, S, JU Kunstler, A Gupta, H Funke, T Reich, C Hennig, A Rossberg, HJ Pietzsch, R Alberto, and B Johannsen. 2000. "EXAFS Analyses of Technetium(I) Carbonyl Complexes - Stability Studies in Solutions." Radiochimica Acta 88(3-4):239-45. 10.1524/ract.2000.88.3-4.239.

Sekine, T, H Narushima, Y Kino, H Kudo, MZ Lin, and Y Katsumura. 2002. "Radiolytic Formation of Tc(IV) Oxide Colloids." Radiochimica Acta 90(9-11):611-16. 10.1524/ract.2002.90.911_2002.611.

Warwick, P, S Aldridge, N Evans, and S Vines. 2007. "The Solubility of Technetium(IV) at High pH." Radiochimica Acta 95(12):709-16. 10.1524/ract.2007.95.12.709.

Xia, YX, NJ Hess, and AR Felmy. 2006. "Stability Constants of Technetium(IV) Oxalate Complexes as a Function of Ionic Strength." Radiochimica Acta 94(3):137-41. 10.1524/ract.2006.94.3.137.

Zehavi, D, and J Rabani. 1971. "Pulse Radiolytic Investigation of Oaq- Radical Ions." J. Phys. Chem. $75: 1738-44$. 


\section{Appendix A: Plots of TWINS data versus \% n-Tc for Hanford Tank Wastes}

This appendix contains the plots showing correlations of $\% \mathrm{n}-\mathrm{Tc}$ versus various Hanford tank variables that are not presented in the body of the report.

Table A - 1: Summary of Values shown in Appendix A Plots of \% n-Tc versus Various Hanford Tank Variables

\begin{tabular}{|c|c|c|c|c|c|c|c|c|}
\hline $\begin{array}{c}\text { Fig. } \\
\#\end{array}$ & Caption & $\begin{array}{l}\text { Correlation } \\
\text { Coefficient, } \\
\text { All Tanks }\end{array}$ & Linear Trend & $\mathrm{R}^{2}$ & $\begin{array}{c}\text { Correlation } \\
\text { Coefficient, } \\
\text { Without AN- } \\
102 \text { AND AN- } \\
107\end{array}$ & $\begin{array}{l}\text { Correlation } \\
\text { Coefficient, } \\
\text { Without } \\
\text { AN-107 }\end{array}$ & $\begin{array}{c}\text { Special } \\
\text { Exclusions }\end{array}$ & Comments \\
\hline 1 & $\begin{array}{c}\text { Total Organic Carbon } \\
\text { (TOC) (All tanks of } \\
\text { interest with data in } \\
\mu \mathrm{g} / \mathrm{mL} \text { ) }\end{array}$ & 0.4997 & & & 0.5718 & & & \\
\hline 2 & $\begin{array}{l}\text { Total Organic Carbon } \\
\text { (TOC) (Without Tanks } \\
\text { AN-102 and AN-107; } \\
\text { with data in } \mu \mathrm{g} / \mathrm{mL} \text { ) }\end{array}$ & & $y=0.0089 x+3.3954$ & $R^{2}=0.3269$ & 0.5718 & & & $\begin{array}{c}\text { Huge error } \\
\text { bars }\end{array}$ \\
\hline 3 & $\begin{array}{l}\text { Total Inorganic Carbon } \\
\text { (TIC) (With and Without } \\
\text { Tanks AN-102 and AN- } \\
\text { 107; with data in } \mu \mathrm{g} / \mathrm{mL} \text { ) }\end{array}$ & 0.3611 & & & -0.142 & & & $\begin{array}{l}\text { Huge error } \\
\text { bars }\end{array}$ \\
\hline 4 & $\begin{array}{c}\text { Nitrite (With and } \\
\text { Without Tanks AN-102 } \\
\text { and AN-107; with data in } \\
\mu \mathrm{g} / \mathrm{mL} \text { ) }\end{array}$ & -0.177 & & & -0.1504 & & & $\begin{array}{l}\text { Huge error } \\
\text { bars }\end{array}$ \\
\hline 5 & $\begin{array}{c}\text { Hydroxide (With and } \\
\text { Without Tanks AN-102 } \\
\text { and AN-107; with data in } \\
\mu \mathrm{g} / \mathrm{mL} \text { ) }\end{array}$ & -0.4435 & & & -0.3184 & & & $\begin{array}{l}\text { Big error } \\
\text { bars }\end{array}$ \\
\hline 6 & $\begin{array}{c}\text { Sodium (With and } \\
\text { Without Tanks AN-102 } \\
\text { and AN-107; with data in }\end{array}$ & 0.0198 & & & -0.1676 & & & $\begin{array}{c}\text { Huge error } \\
\text { bars }\end{array}$ \\
\hline
\end{tabular}




\begin{tabular}{|c|c|c|c|c|c|c|c|c|}
\hline $\begin{array}{c}\text { Fig. } \\
\#\end{array}$ & Caption & $\begin{array}{l}\text { Correlation } \\
\text { Coefficient, } \\
\text { All Tanks }\end{array}$ & Linear Trend & $R^{2}$ & $\begin{array}{c}\text { Correlation } \\
\text { Coefficient, } \\
\text { Without AN- } \\
102 \text { AND AN- } \\
107\end{array}$ & $\begin{array}{c}\text { Correlation } \\
\text { Coefficient, } \\
\text { Without } \\
\text { AN-107 }\end{array}$ & $\begin{array}{c}\text { Special } \\
\text { Exclusions }\end{array}$ & Comments \\
\hline & $\mu \mathrm{g} / \mathrm{mL})$ & & & & & & & \\
\hline 7 & $\begin{array}{l}\text { Technetium-99 in } \\
\text { Supernatant (Data } \\
\text { reported in } \mu \mathrm{g} / \mathrm{mL} \text { ) }\end{array}$ & -0.1893 & & & -0.0045 & & & $\begin{array}{l}\text { Huge error } \\
\text { bars }\end{array}$ \\
\hline 8 & $\begin{array}{l}\text { Technetium-99 in } \\
\text { Supernatant (Data } \\
\text { reported in } \mu \mathrm{Ci} / \mathrm{mL} \text { ) }\end{array}$ & -0.3378 & & & -0.2371 & & & $\begin{array}{l}\text { Huge error } \\
\text { bars }\end{array}$ \\
\hline 9 & $\begin{array}{c}\text { Soluble Transuranics - } \\
{ }^{241} \mathrm{Am} \text { (Data reported in } \\
\mu \mathrm{Ci} / \mathrm{mL} \text { ) }\end{array}$ & -0.485 & & & -0.5934 & & & $\begin{array}{l}\text { Huge error } \\
\text { bars }\end{array}$ \\
\hline 10 & $\begin{array}{c}\text { Soluble Transuranics - } \\
\mathrm{Pu} \text { (Data reported in } \\
\mu \mathrm{Ci} / \mathrm{mL} \text { ) }\end{array}$ & 0.1299 & & & -0.9559 & & & $\begin{array}{c}\text { Big error } \\
\text { bars }\end{array}$ \\
\hline 11 & $\begin{array}{l}\text { Soluble Transuranics - } \\
\text { Pu (Data reported in } \\
\mu \mathrm{Ci} / \mathrm{mL} \text { ) (Without Tanks } \\
\text { AN-102 and AN-107) }\end{array}$ & & & & -0.9559 & & & \\
\hline 12 & $\begin{array}{l}\text { Soluble Transuranics - } \\
\text { Pu (Data reported in } \\
\mu \mathrm{g} / \mathrm{mL} \text { ) (Without Tanks } \\
\text { AN-102 and AN-107) }\end{array}$ & & $y=0.9229 x+1.5233$ & $R^{2}=0.3594$ & 0.5995 & & & $\begin{array}{c}\text { Very limited } \\
\text { data }\end{array}$ \\
\hline 13 & $\begin{array}{l}\text { Soluble Transuranics }-\mathrm{Sr} \\
\text { (Data reported in } \mu \mathrm{Ci} / \mathrm{mL} \\
\text { ) }\end{array}$ & 0.4487 & & & 0.3394 & & & \\
\hline 14 & $\begin{array}{c}\text { Soluble Transuranics }-\mathrm{Sr} \\
\text { (Data reported in } \mu \mathrm{Ci} / \mathrm{mL} \\
\text { ) (Without Tanks AN-102 } \\
\text { and AN-107) }\end{array}$ & & $y=11.87 x+18.496$ & $R^{2}=0.1152$ & 0.3394 & & & $\begin{array}{l}\text { Huge error } \\
\text { bars }\end{array}$ \\
\hline 15 & $\begin{array}{l}\text { Soluble Transuranics }-\mathrm{Sr} \\
\text { (Data reported in } \mu \mathrm{g} / \mathrm{mL} \text { ) } \\
\text { (With and Without Tanks }\end{array}$ & -0.2901 & & & -0.2959 & & & $\begin{array}{l}\text { Huge error } \\
\text { bars }\end{array}$ \\
\hline
\end{tabular}




\begin{tabular}{|c|c|c|c|c|c|c|c|c|}
\hline $\begin{array}{c}\text { Fig. } \\
\#\end{array}$ & Caption & $\begin{array}{l}\text { Correlation } \\
\text { Coefficient, } \\
\text { All Tanks }\end{array}$ & Linear Trend & $\mathrm{R}^{2}$ & $\begin{array}{c}\text { Correlation } \\
\text { Coefficient, } \\
\text { Without AN- } \\
102 \text { AND AN- } \\
107\end{array}$ & $\begin{array}{l}\text { Correlation } \\
\text { Coefficient, } \\
\text { Without } \\
\text { AN-107 }\end{array}$ & $\begin{array}{l}\text { Special } \\
\text { Exclusions }\end{array}$ & Comments \\
\hline & AN-102 and AN-107) & & & & & & & \\
\hline 16 & $\begin{array}{c}\text { Technetium-99 - Solids } \\
\text { Phase (Without Tank AN- } \\
\text { 107, but with Tank AN- } \\
\text { 102) (Data reported in } \\
\mu \mathrm{Ci} / \mathrm{g} \text { ) }\end{array}$ & & $y=37.676 x+26.445$ & $R^{2}=0.0048$ & & 0.0692 & $\begin{array}{c}\text { NOTE: Solids } \\
\text { Phase; NOT } \\
\text { supernatant }\end{array}$ & $\begin{array}{l}\text { Huge error } \\
\text { bars }\end{array}$ \\
\hline 17 & $\begin{array}{l}\text { Techetium-99 - Solids } \\
\text { Phase (Without Tanks } \\
\text { AN-102 and AN-107) } \\
\text { (Data reported in } \mu \mathrm{Ci} / \mathrm{g} \text { ) }\end{array}$ & & $y=348.1 x-43.346$ & $R^{2}=0.2851$ & 0.5340 & & $\begin{array}{c}\text { NOTE: Solids } \\
\text { Phase; NOT } \\
\text { supernatant }\end{array}$ & $\begin{array}{l}\text { Huge error } \\
\text { bars }\end{array}$ \\
\hline 18 & $\begin{array}{l}\text { Soluble Aluminum (Data } \\
\text { reported in } \mu \mathrm{g} / \mathrm{mL} \text { ) }\end{array}$ & & $y=0.0016 x+14.383$ & $R^{2}=0.3604$ & 0.6003 & & $\begin{array}{l}\text { NOTE: Solids } \\
\text { Phase; NOT } \\
\text { supernatant }\end{array}$ & $\begin{array}{l}\text { Huge error } \\
\text { bars; very } \\
\text { limited data }\end{array}$ \\
\hline 19 & $\begin{array}{l}\text { Noble Metals in Solid } \\
\text { Phase - Palladium (Data } \\
\text { in } \mu \mathrm{g} / \mathrm{g} \text { ) }\end{array}$ & & $y=0.0012 x+29.019$ & $R^{2}=0.0126$ & 0.1121 & & & $\begin{array}{l}\text { Huge error } \\
\text { bars; very } \\
\text { limited data }\end{array}$ \\
\hline 20 & $\begin{array}{l}\text { Noble Metals in Solid } \\
\text { Phase - Platinum (Data } \\
\text { in } \mu \mathrm{g} / \mathrm{g} \text { ) }\end{array}$ & 0.1105 & $y=5.1892 x+39.126$ & $R^{2}=0.0122$ & & & $\begin{array}{c}\text { AN-102; AN- } \\
\text { 107; AZ-101 } \\
\text { tanks only }\end{array}$ & $\begin{array}{l}\text { Huge error } \\
\text { bars; very } \\
\text { limited data }\end{array}$ \\
\hline 21 & $\begin{array}{l}\text { Noble Metals in Solid } \\
\text { Phase - Rhodium (Data } \\
\text { in } \mu \mathrm{g} / \mathrm{g} \text { ) }\end{array}$ & & $y=0.0024 x+26.126$ & $R^{2}=0.0404$ & 0.2011 & & & $\begin{array}{l}\text { Huge error } \\
\text { bars; very } \\
\text { limited data }\end{array}$ \\
\hline 22 & $\begin{array}{l}\text { Noble Metals in Solid } \\
\text { Phase - Ruthenium } \\
\text { (Data in } \mu \mathrm{g} / \mathrm{g} \text { ) }\end{array}$ & & $y=0.0007 x+28.461$ & $R^{2}=0.0169$ & 0.1302 & & & $\begin{array}{l}\text { Huge error } \\
\text { bars; very } \\
\text { limited data }\end{array}$ \\
\hline 23 & $\begin{array}{c}\text { Noble Metals in Solid } \\
\text { Phase - } \\
\text { Ruthenium/Rhodium- } \\
106 \text { (Data in } \mu \mathrm{Ci} / \mathrm{g} \text { ) }\end{array}$ & -0.5448 & $y=-0.1657 x+34.5$ & $R^{2}=0.2968$ & & & $\begin{array}{c}\text { AZ-101; AZ- } \\
\text { 102; SY-101 } \\
\text { tanks only }\end{array}$ & $\begin{array}{l}\text { Huge error } \\
\text { bars; very } \\
\text { limited data }\end{array}$ \\
\hline
\end{tabular}




\begin{tabular}{|c|c|c|c|c|c|c|c|c|}
\hline $\begin{array}{c}\text { Fig. } \\
\#\end{array}$ & Caption & $\begin{array}{l}\text { Correlation } \\
\text { Coefficient, } \\
\text { All Tanks }\end{array}$ & Linear Trend & $\mathbf{R}^{2}$ & $\begin{array}{c}\text { Correlation } \\
\text { Coefficient, } \\
\text { Without AN- } \\
102 \text { AND AN- } \\
107\end{array}$ & $\begin{array}{l}\text { Correlation } \\
\text { Coefficient, } \\
\text { Without } \\
\text { AN-107 }\end{array}$ & $\begin{array}{l}\text { Special } \\
\text { Exclusions }\end{array}$ & Comments \\
\hline 24 & $\begin{array}{l}\text { Unit Liter Dose (ULD) - } \\
\text { All Tanks of Interest } \\
\text { (Data in Sv/L) }\end{array}$ & 0.1231 & $y=-0.0146 x+34.505$ & $R^{2}=0.0152$ & & & & $\begin{array}{l}\text { reasonable } \\
\text { error bars }\end{array}$ \\
\hline 25 & $\begin{array}{c}\text { Unit Liter Dose (ULD) - } \\
\text { Without Tanks AN-102 } \\
\text { and AN-107 (Data in } \\
\text { Sv/L) }\end{array}$ & & $y=-0.193 x+57.706$ & $R^{2}=0.4582$ & -0.6769 & & & $\begin{array}{l}\text { couple of } \\
\text { big error } \\
\text { bars }\end{array}$ \\
\hline 26 & $\begin{array}{l}\text { Unit Liter Dose (ULD), } \\
\text { "Offsite"- All Tanks of } \\
\text { Interest (Data in Sv/L) }\end{array}$ & 0.2643 & $y=0.0209 x+32.367$ & $R^{2}=0.0699$ & & & & $\begin{array}{l}\text { reasonable } \\
\text { error bars }\end{array}$ \\
\hline 27 & $\begin{array}{l}\text { Unit Liter Dose (ULD), } \\
\text { "Offiste" - Without } \\
\text { Tanks AN-102 and AN- } \\
107 \text { (Data in Sv/L) }\end{array}$ & & $y=-0.2747 x+58.645$ & $R^{2}=0.4492$ & -0.6702 & & & $\begin{array}{l}\text { couple of } \\
\text { big error } \\
\text { bars }\end{array}$ \\
\hline 28 & $\begin{array}{c}\text { Dose from }{ }^{137} \mathrm{Cs} \text { (Data in } \\
\mathrm{Bq} / \mathrm{L} \text { ) }\end{array}$ & -0.6900 & $y=-1.46 E-09 x+64.687$ & $R^{2}=0.4760$ & & & & $\begin{array}{l}\text { couple of } \\
\text { big error } \\
\text { bars }\end{array}$ \\
\hline 29 & $\begin{array}{l}\text { Dose from }{ }^{137} \mathrm{Cs} \text { (Data in } \\
\text { Bq/L) (without Tank AZ- } \\
\text { 101) }\end{array}$ & & $y=-2.95 E-09 x+82.862$ & $R^{2}=0.5415$ & & & $\begin{array}{c}\text { CC: }-0.7359 \times \\
10^{-1} \text { without } \\
\text { Tank AZ-101 }\end{array}$ & \\
\hline 30 & $\begin{array}{c}\text { Dose from }{ }^{137} \mathrm{Cs} \text { (Data in } \\
\mathrm{Bq} / \mathrm{L} \text { ) (without Tanks AN- } \\
102 \text { and AN-107) }\end{array}$ & & $y=-1.32 E-09 x+56.743$ & $R^{2}=0.4653$ & -0.6821 & & & $\begin{array}{l}\text { couple of } \\
\text { big error } \\
\text { bars }\end{array}$ \\
\hline 31 & $\begin{array}{c}\text { Dose from }{ }^{137} \mathrm{Cs} \text { (Data in } \\
\mathrm{Bq} / \mathrm{L} \text { ) (without Tanks AN- } \\
\text { 102, AN-107, and AZ- } \\
\text { 101) }\end{array}$ & & $y=-2.85 E-09 x+75.316$ & $R^{2}=0.5967$ & -0.7724 & & & \\
\hline 32 & $\begin{array}{c}\text { Dose from }{ }^{89 / 90} \mathrm{Sr} \text {, All } \\
\text { tanks of interest (Data in } \\
\mu \mathrm{Ci} / \mathrm{mL} \text { ) }\end{array}$ & 0.5378 & $y=0.5538 x+27.888$ & $R^{2}=0.2892$ & & & & $\begin{array}{l}\text { couple of } \\
\text { big error } \\
\text { bars }\end{array}$ \\
\hline
\end{tabular}




\begin{tabular}{|c|c|c|c|c|c|c|c|c|}
\hline $\begin{array}{c}\text { Fig. } \\
\#\end{array}$ & Caption & $\begin{array}{l}\text { Correlation } \\
\text { Coefficient, } \\
\text { All Tanks }\end{array}$ & Linear Trend & $R^{2}$ & $\begin{array}{c}\text { Correlation } \\
\text { Coefficient, } \\
\text { Without AN- } \\
102 \text { AND AN- } \\
107\end{array}$ & $\begin{array}{l}\text { Correlation } \\
\text { Coefficient, } \\
\text { Without } \\
\text { AN-107 }\end{array}$ & $\begin{array}{c}\text { Special } \\
\text { Exclusions }\end{array}$ & Comments \\
\hline 33 & $\begin{array}{c}\text { Dose from }{ }^{89 / 90} \mathrm{Sr} \\
\text { (Without Tanks AN-102 } \\
\text { and AN-107) (Data in } \\
\mu \mathrm{Ci} / \mathrm{mL} \text { ) }\end{array}$ & & $y=1.7021 x+26.313$ & $R^{2}=0.0052$ & 0.0720 & & & $\begin{array}{l}\text { one huge } \\
\text { error bar; } \\
\text { limited data }\end{array}$ \\
\hline 34 & $\begin{array}{l}\text { Dose from }{ }^{90} \mathrm{Sr} \text {, All tanks } \\
\text { of interest (Data in } \mathrm{Bq} / \mathrm{L})\end{array}$ & 0.4552 & $y=1.30 E-08 x+29.845$ & $R^{2}=0.2072$ & & & & $\begin{array}{l}\text { reasonable } \\
\text { error bars }\end{array}$ \\
\hline 35 & $\begin{array}{l}\text { Dose from }{ }^{90} \mathrm{Sr} \text { (Without } \\
\text { Tanks AN-102 and AN- } \\
\text { 107) (Data in } \mathrm{Bq} / \mathrm{L} \text { ) }\end{array}$ & & $y=1.73 E-07 x+22.916$ & $R^{2}=0.0426$ & 0.2065 & & & $\begin{array}{c}\text { reasonable } \\
\text { error bars }\end{array}$ \\
\hline 36 & $\begin{array}{l}\text { Nitrate (All tanks; Data in } \\
\qquad \mu \mathrm{g} / \mathrm{mL})\end{array}$ & 0.4492 & $y=0.0002 x+9.9571$ & $R^{2}=0.2018$ & & & & $\begin{array}{l}\text { reasonable } \\
\text { error bars }\end{array}$ \\
\hline 37 & $\begin{array}{l}\text { Nitrate (Without Tanks } \\
\text { AN-102 and AN-107; } \\
\text { Data in } \mu \mathrm{g} / \mathrm{mL} \text { ) }\end{array}$ & & $y=0.0001 x+16.012$ & $R^{2}=0.0556$ & 0.2358 & & & $\begin{array}{c}\text { reasonable } \\
\text { error bars }\end{array}$ \\
\hline
\end{tabular}




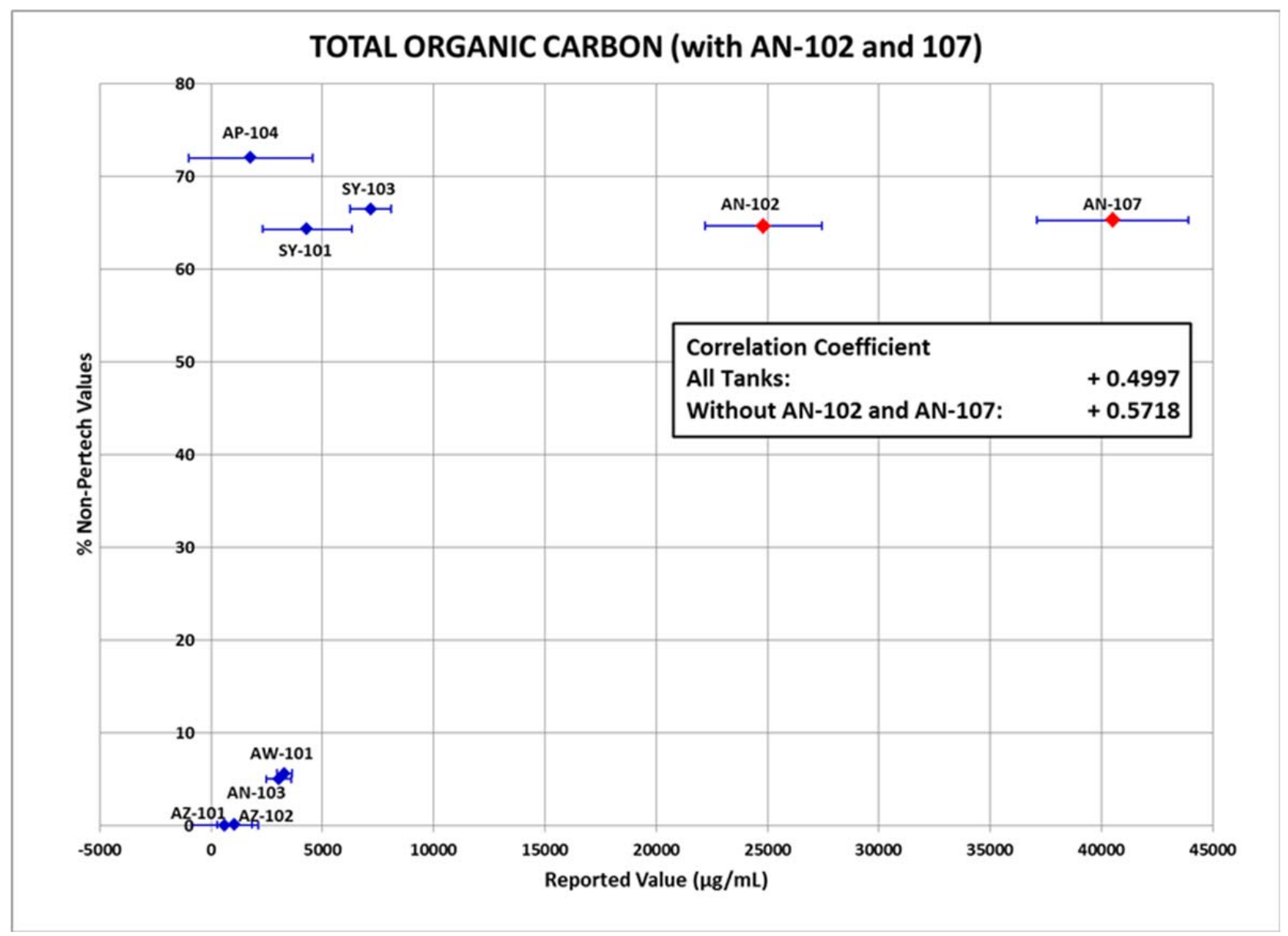

Figure A - 1: Total organic carbon (TOC), including all tanks of interest (data in $\mu \mathrm{g} / \mathrm{mL}$ ) 


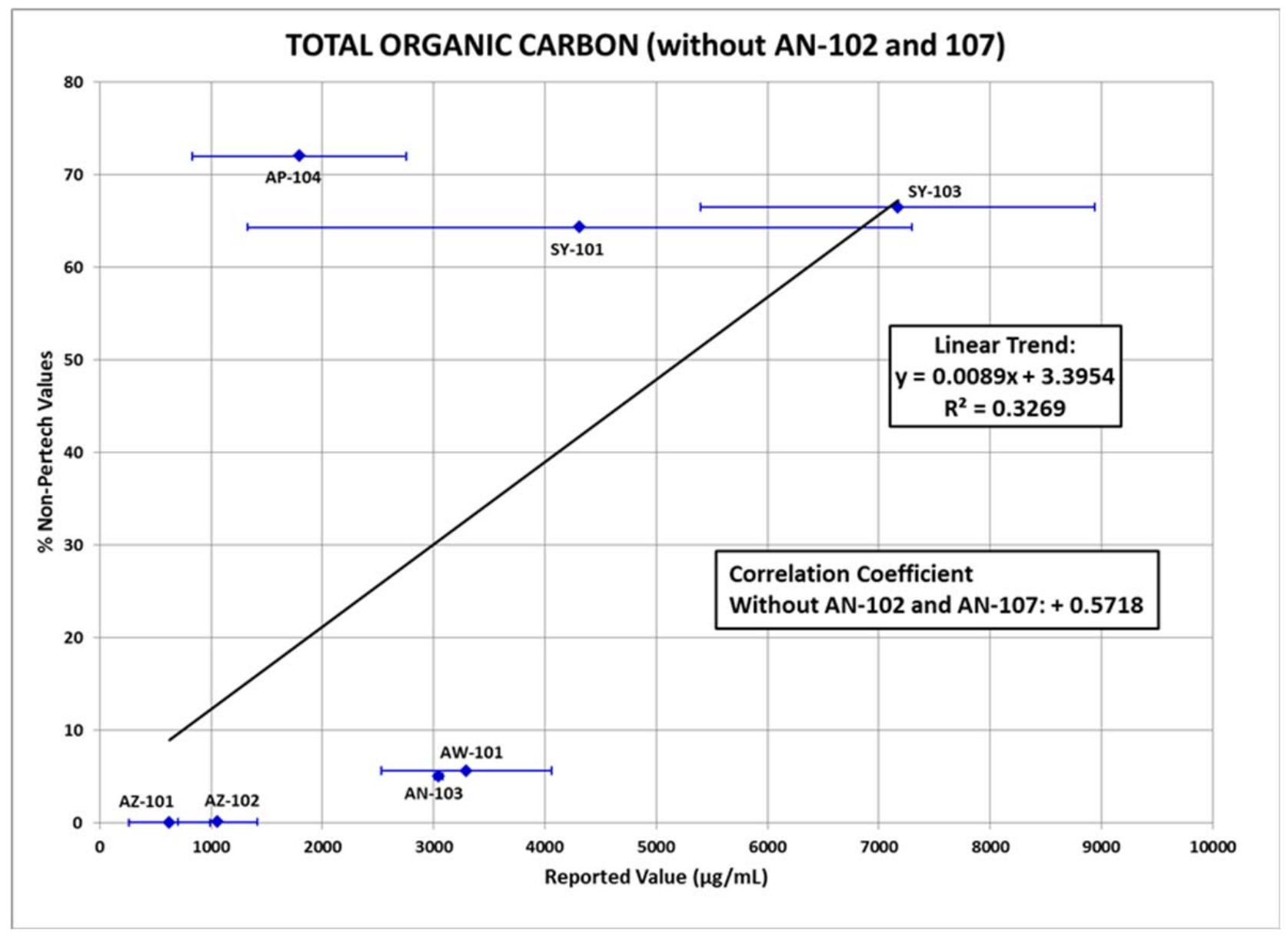

Figure A - 2: TOC, without tanks $\mathrm{AN}-102$ and $\mathrm{AN}-107$ (in $\mu \mathrm{g} / \mathrm{mL}$ ) 


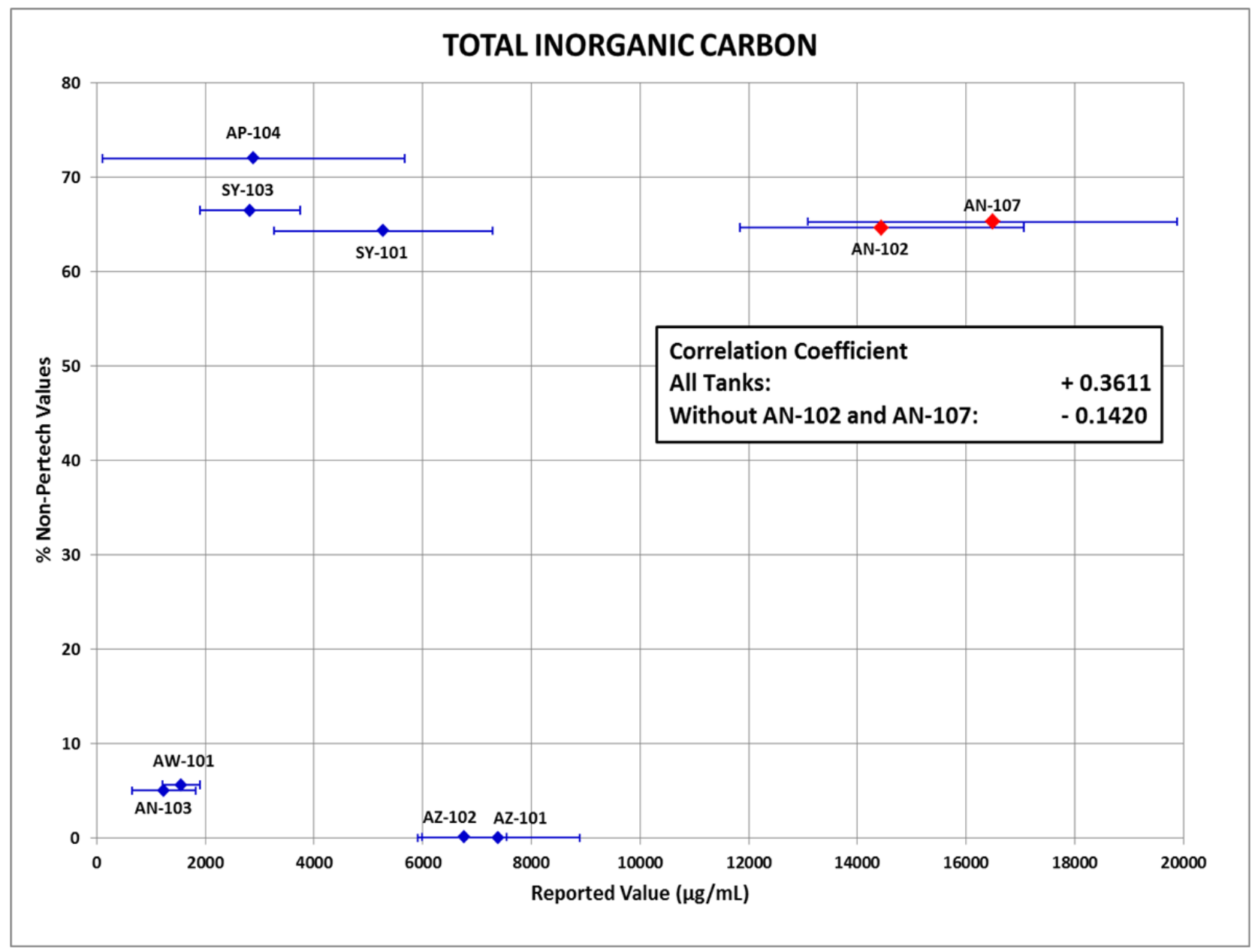

Figure A - 3: Total inorganic carbon (TIC), with and without tanks AN-102 and AN-107 (in $\mu \mathrm{g} / \mathrm{mL}$ ) 


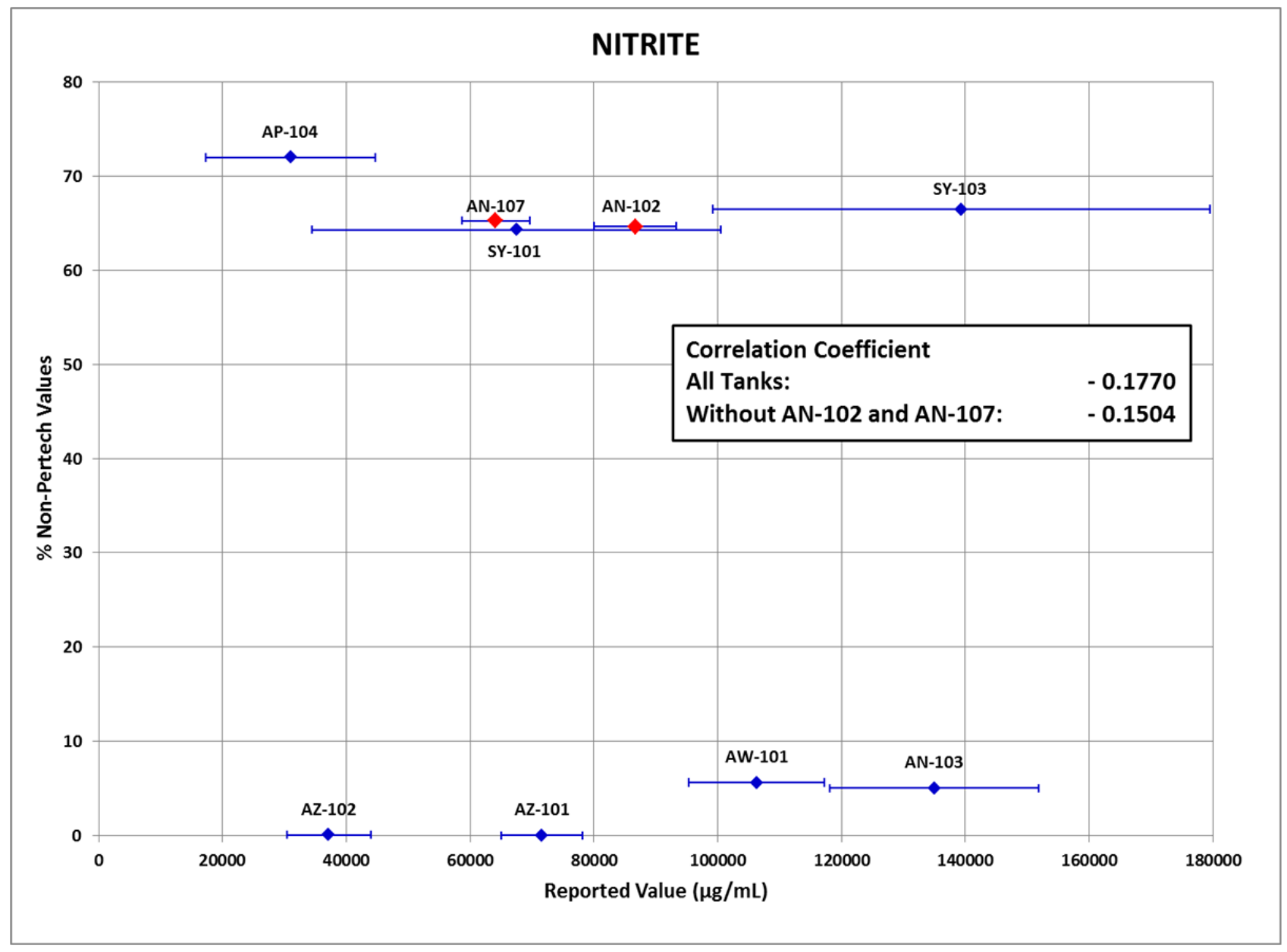

Figure A - 4: Nitrite with and without tanks AN-102 and AN-107 (in $\mu \mathrm{g} / \mathrm{mL})$ 


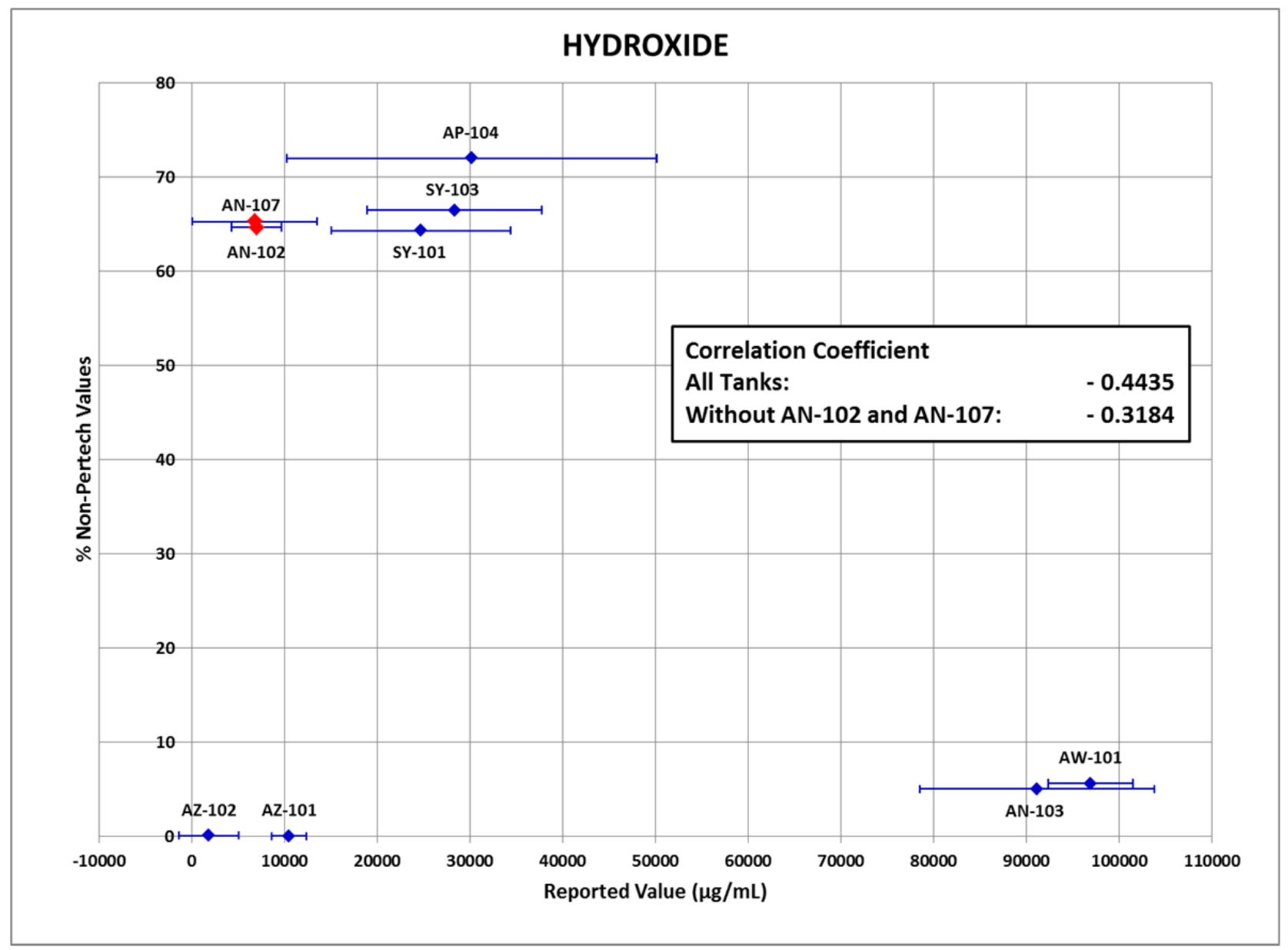

Figure A - 5: Hydroxide with and without tanks AN-102 and AN-107 (in $\mu \mathrm{g} / \mathrm{mL}$ ) 


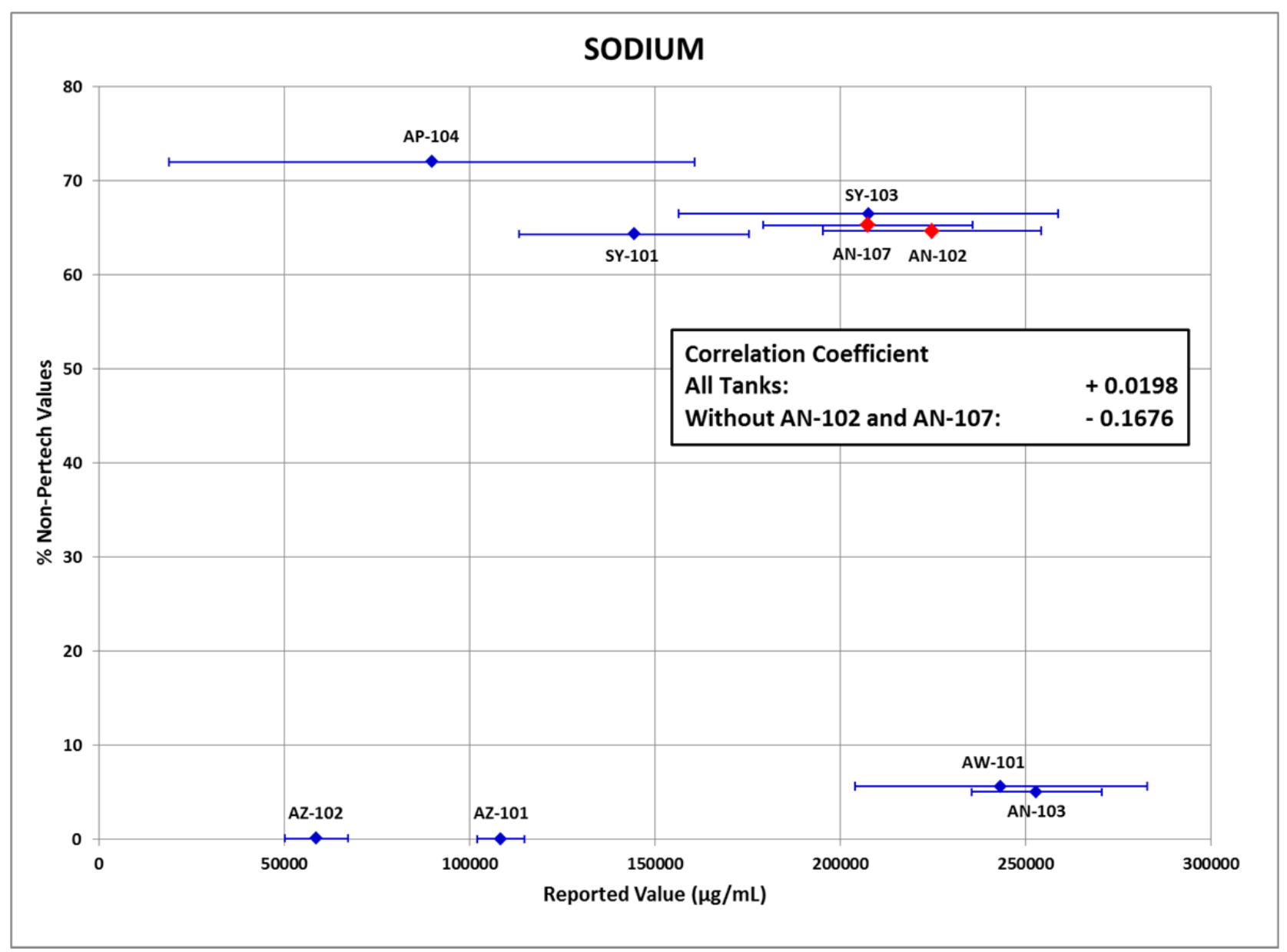

Figure A - 6: Sodium with and without Tanks AN-102 and AN-107 (in $\mu \mathrm{g} / \mathrm{mL})$ 


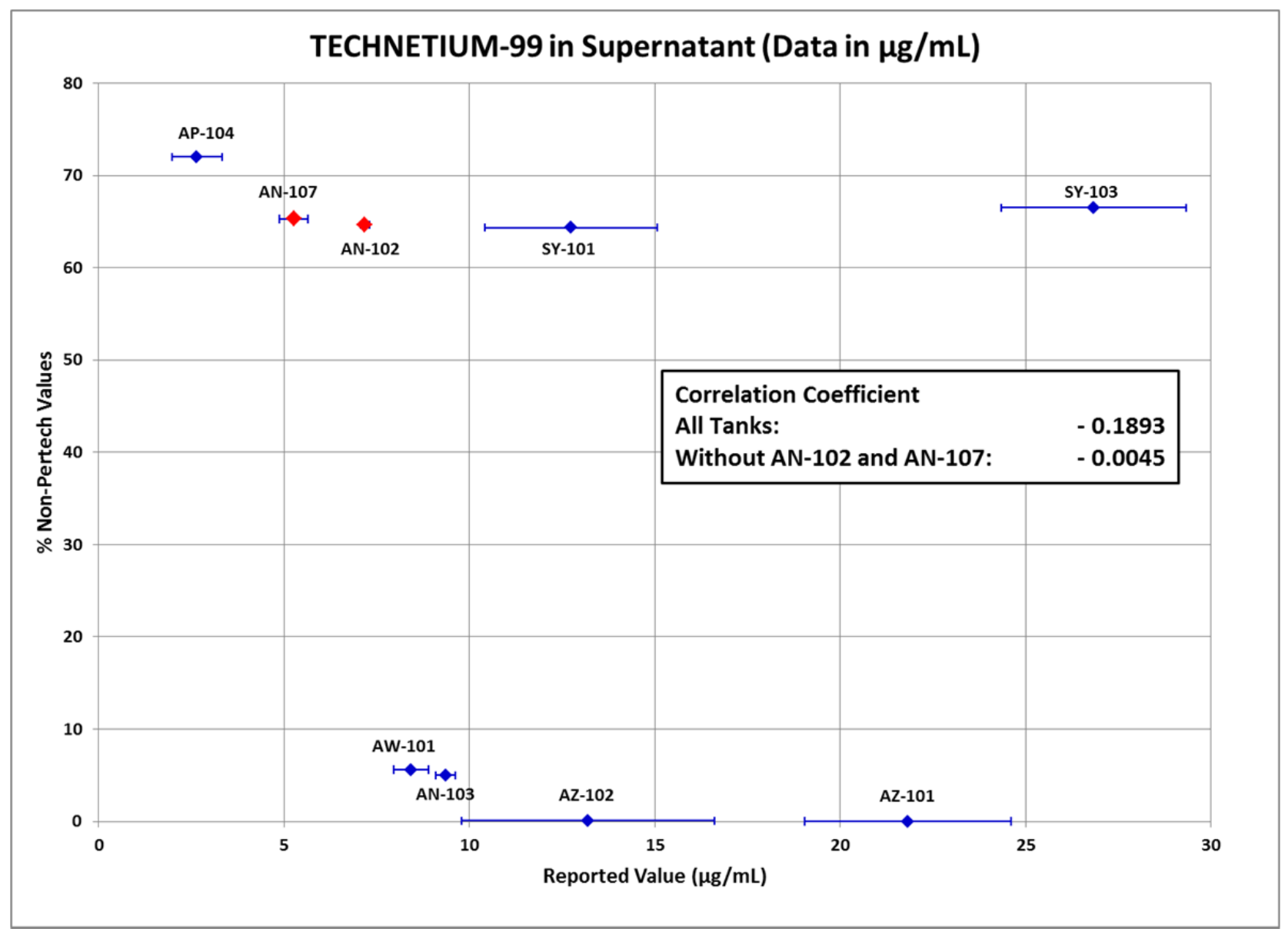

Figure A - 7: Technetium-99 in supernatant (in $\mu \mathrm{g} / \mathrm{mL}$ ) 


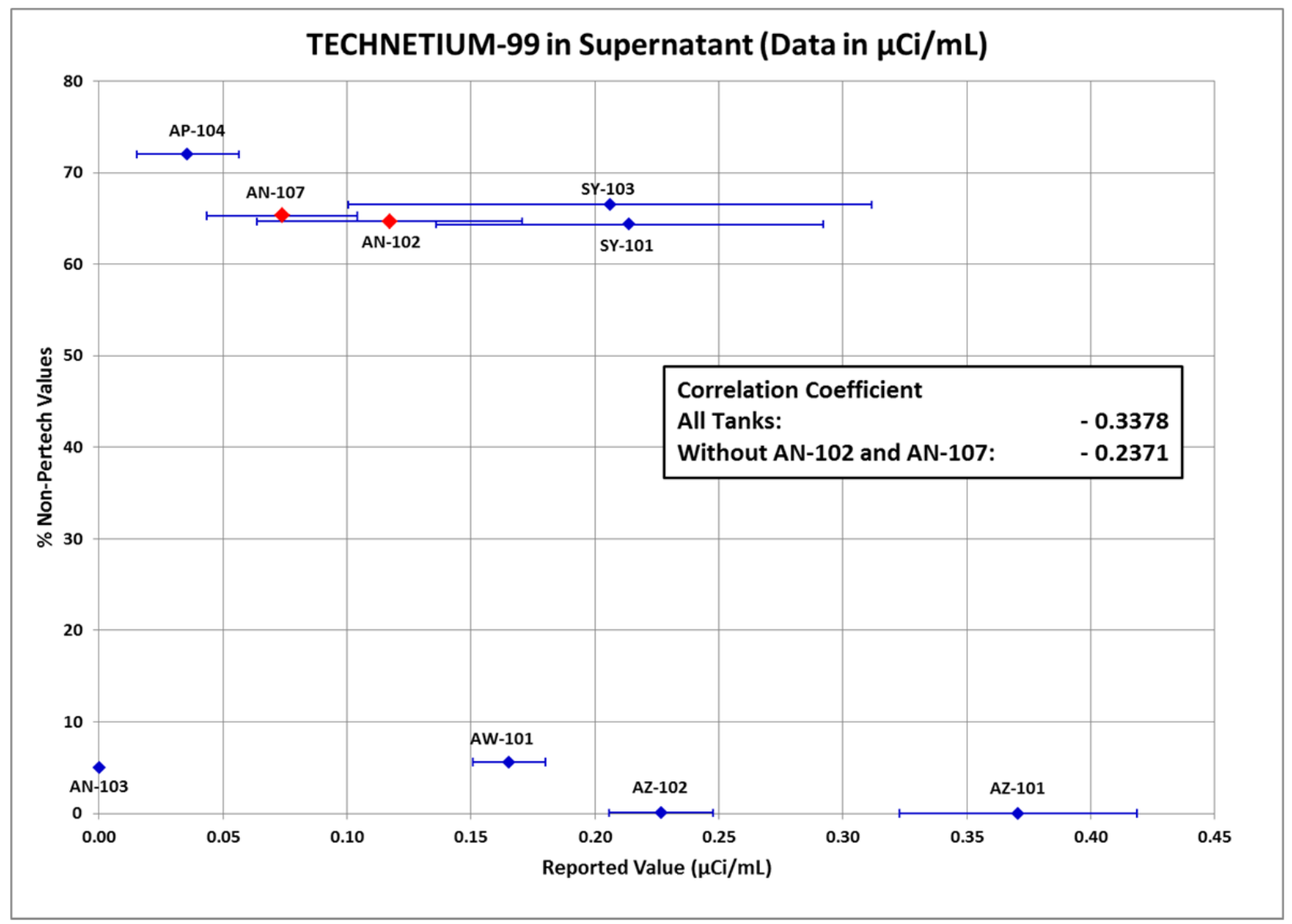

Figure A - 8: Technetium-99 in supernatant $(\mu \mathrm{Ci} / \mathrm{mL})$ 


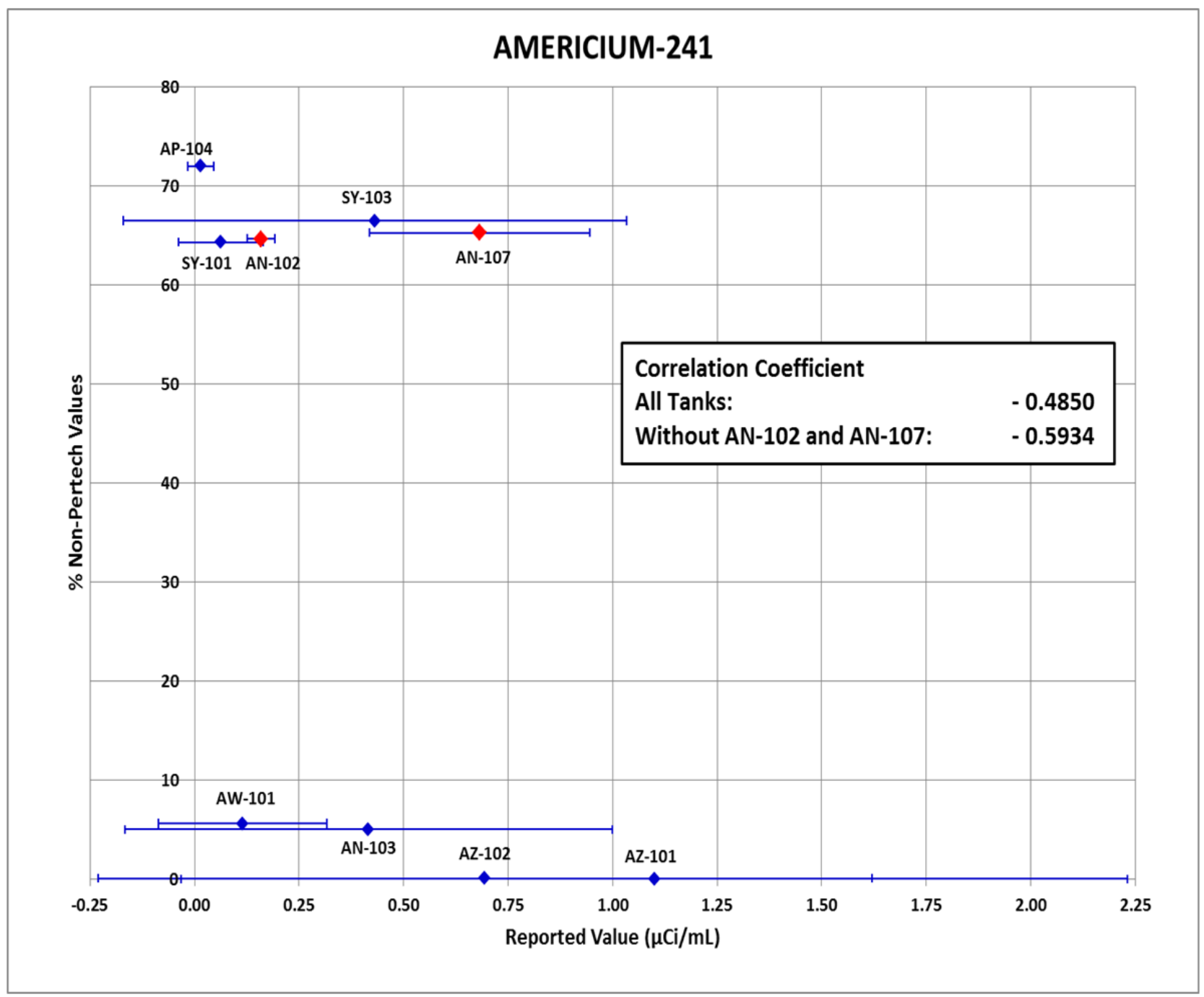

Figure A - 9: Soluble transuranics $-{ }^{241} \mathrm{Am}(\mu \mathrm{Ci} / \mathrm{mL})$ 


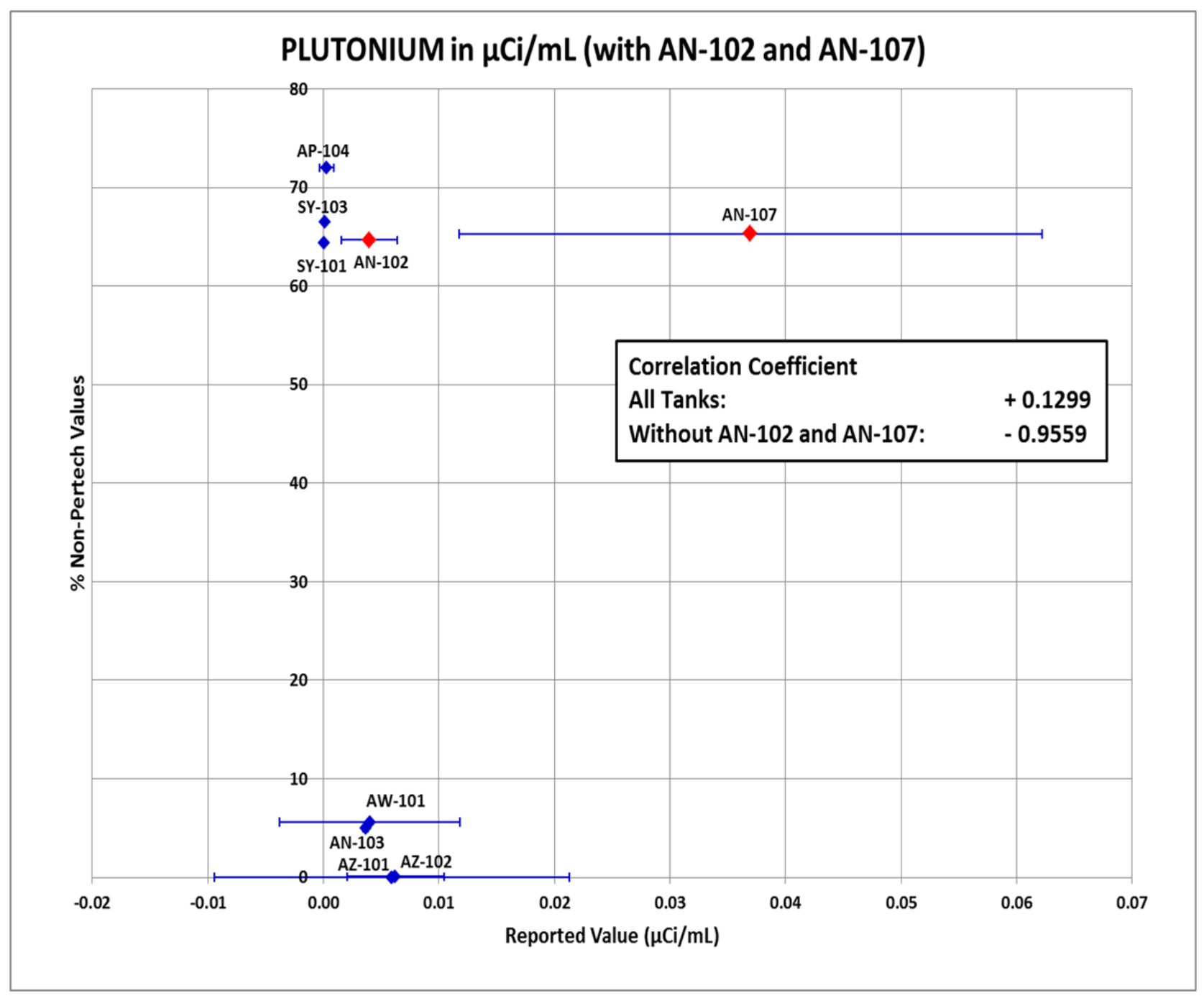

Figure A - 10: Soluble transuranics - plutonium, with tanks AN-102 and AN-107 $(\mu \mathrm{Ci} / \mathrm{mL})$ 


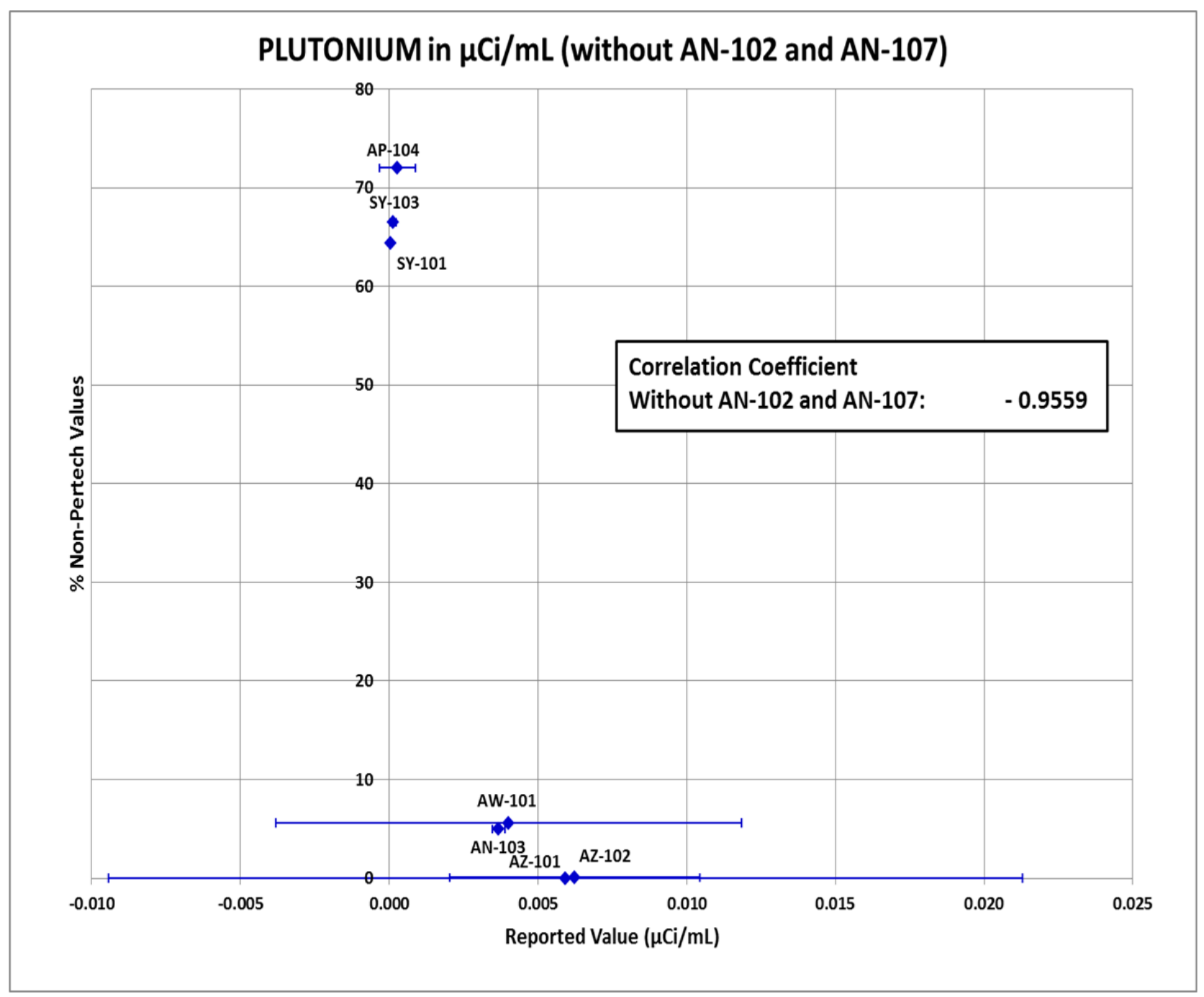

Figure A - 11: Soluble transuranics - plutonium (in $\mu \mathrm{Ci} / \mathrm{mL}$ ) without tanks $\mathrm{AN}-102$ and $\mathrm{AN}-107$ 


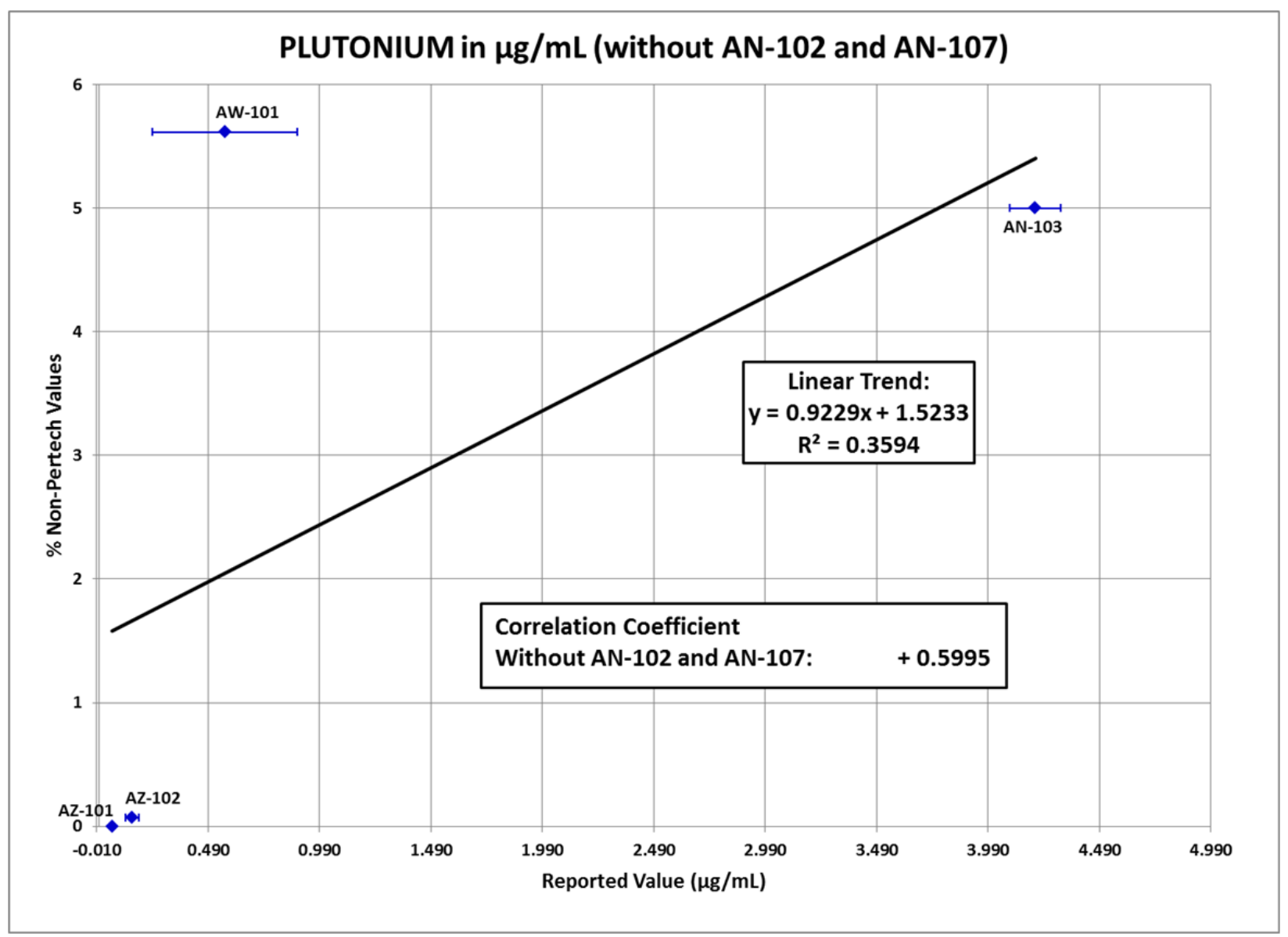

Figure A - 12: Soluble transuranics - plutonium $(\mu \mathrm{g} / \mathrm{mL})$ without tanks $\mathrm{AN}-102$ and $\mathrm{AN}-107$ 


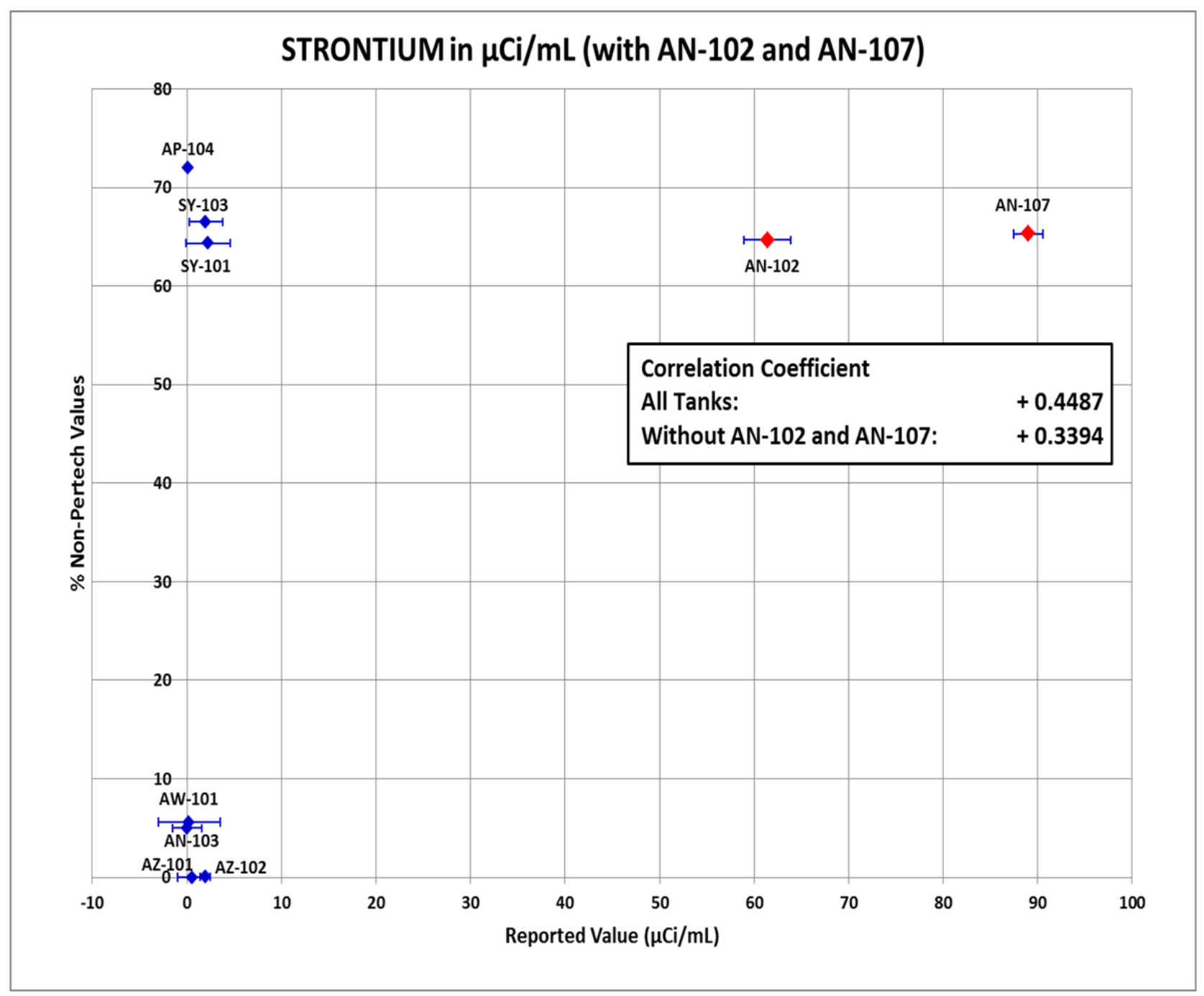

Figure A - 13: Soluble transuranics - strontium $(\mu \mathrm{Ci} / \mathrm{mL})$ with tanks $\mathrm{AN}-102$ and $\mathrm{AN}-107$ 


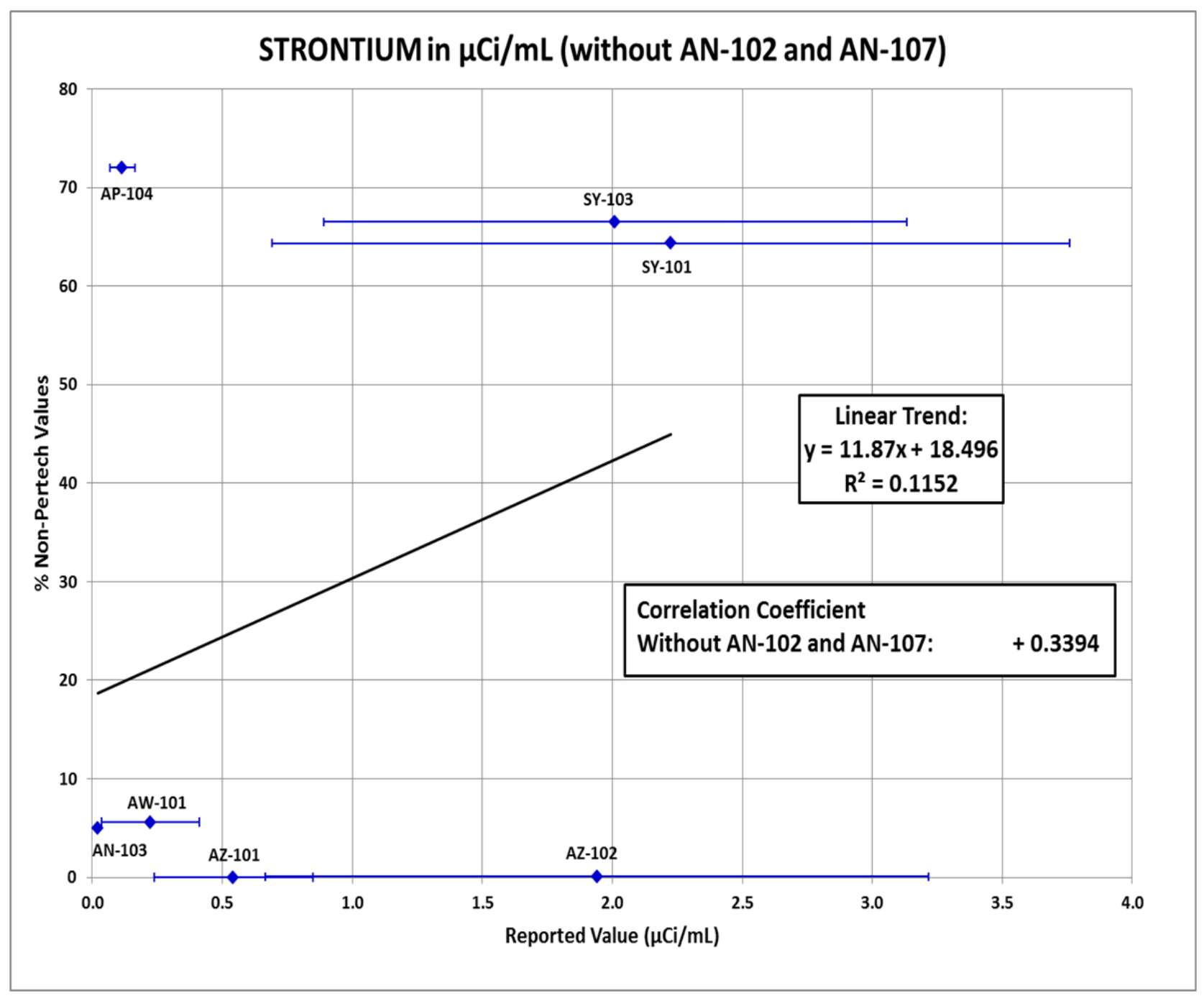

Figure A - 14: Soluble transuranics - strontium (in $\mu \mathrm{Ci} / \mathrm{mL}$ ) without tanks $\mathrm{AN}-102$ and $\mathrm{AN}-107$ 


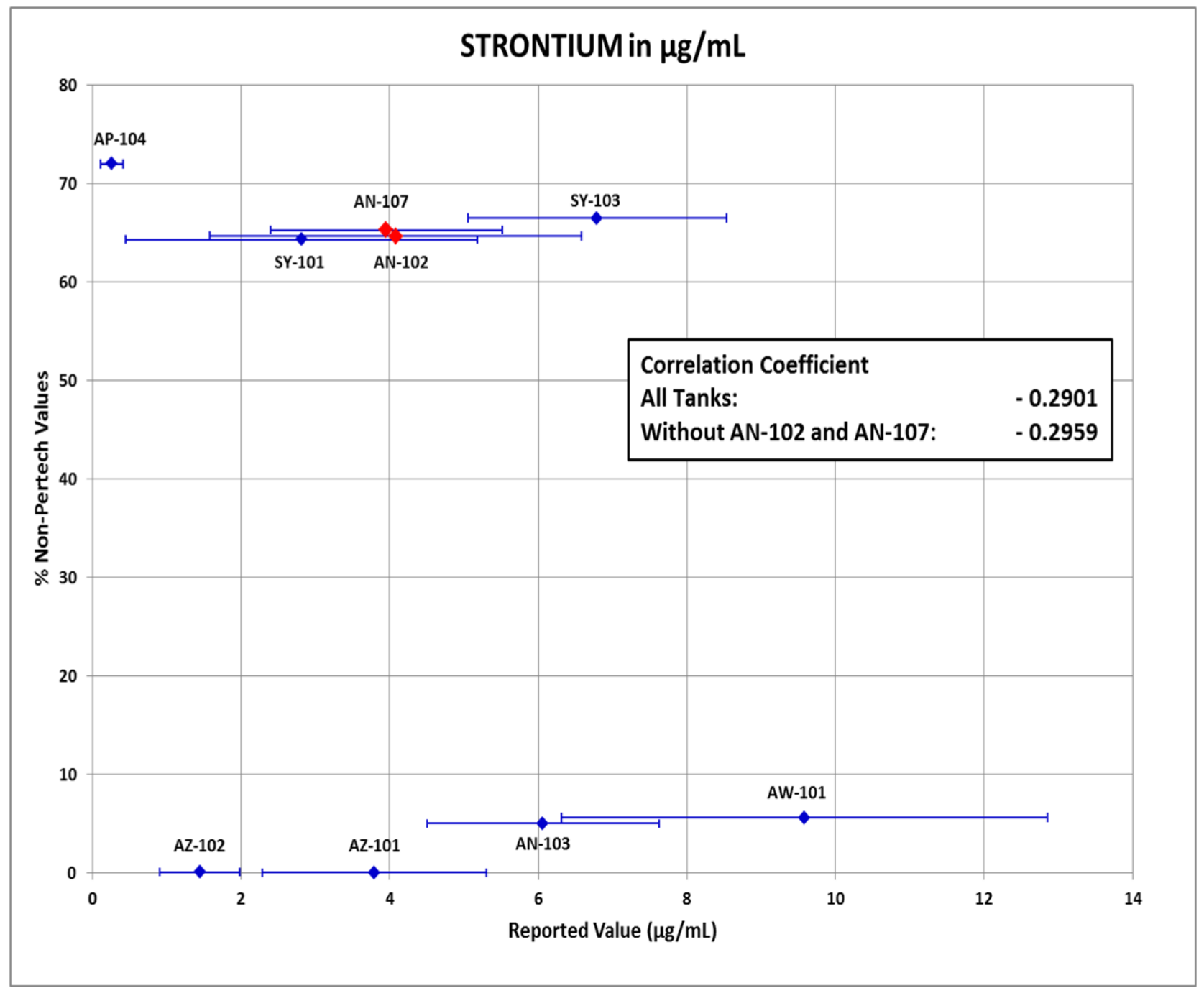

Figure A - 15: Soluble transuranics - strontium $(\mu \mathrm{g} / \mathrm{mL})$ with and without tanks AN-102 and AN-107 


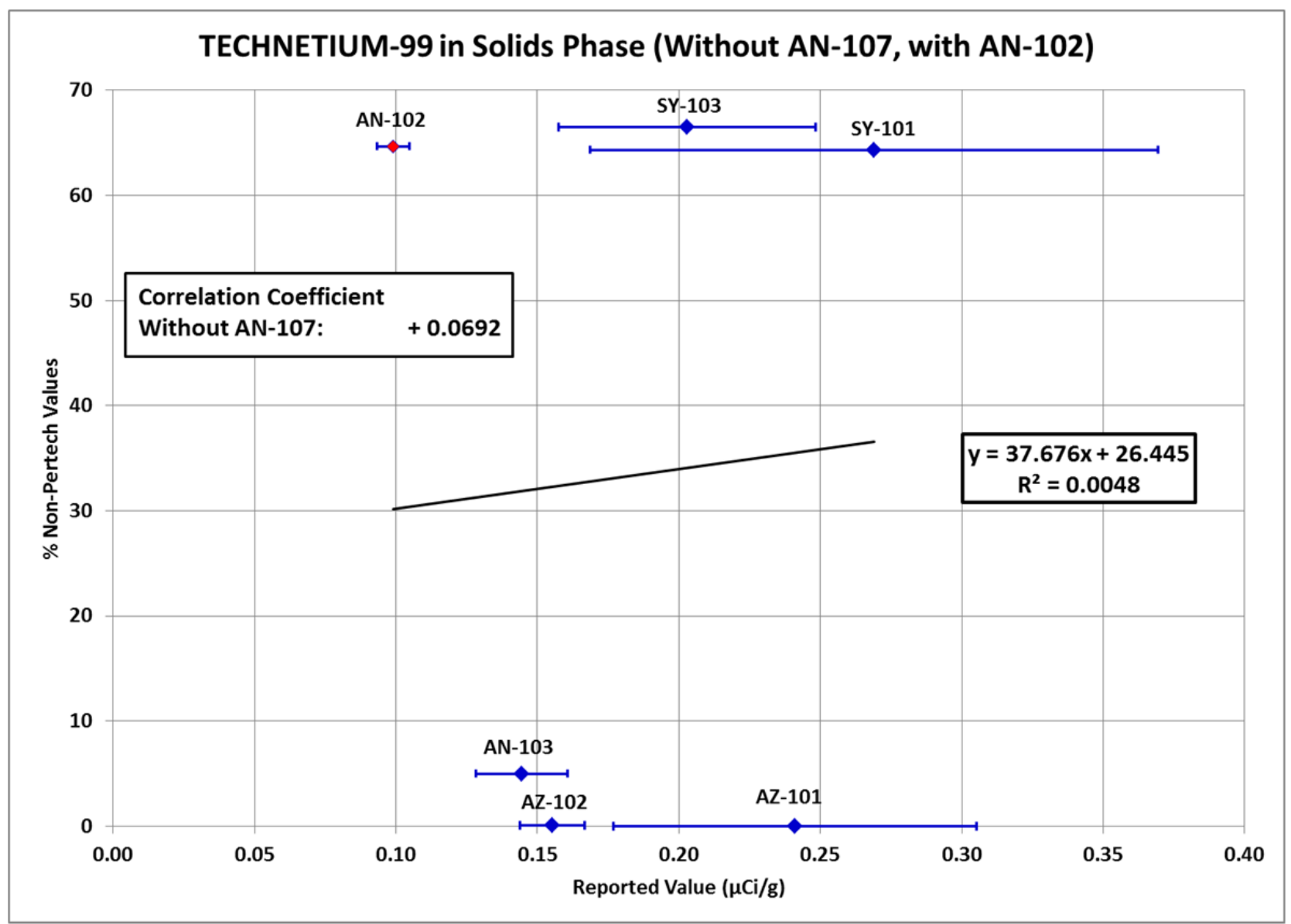

Figure A - 16: Technetium-99 - solids phase without tank AN-107, but with tank AN-102 $(\mu \mathrm{Ci} / \mathrm{g})$ 


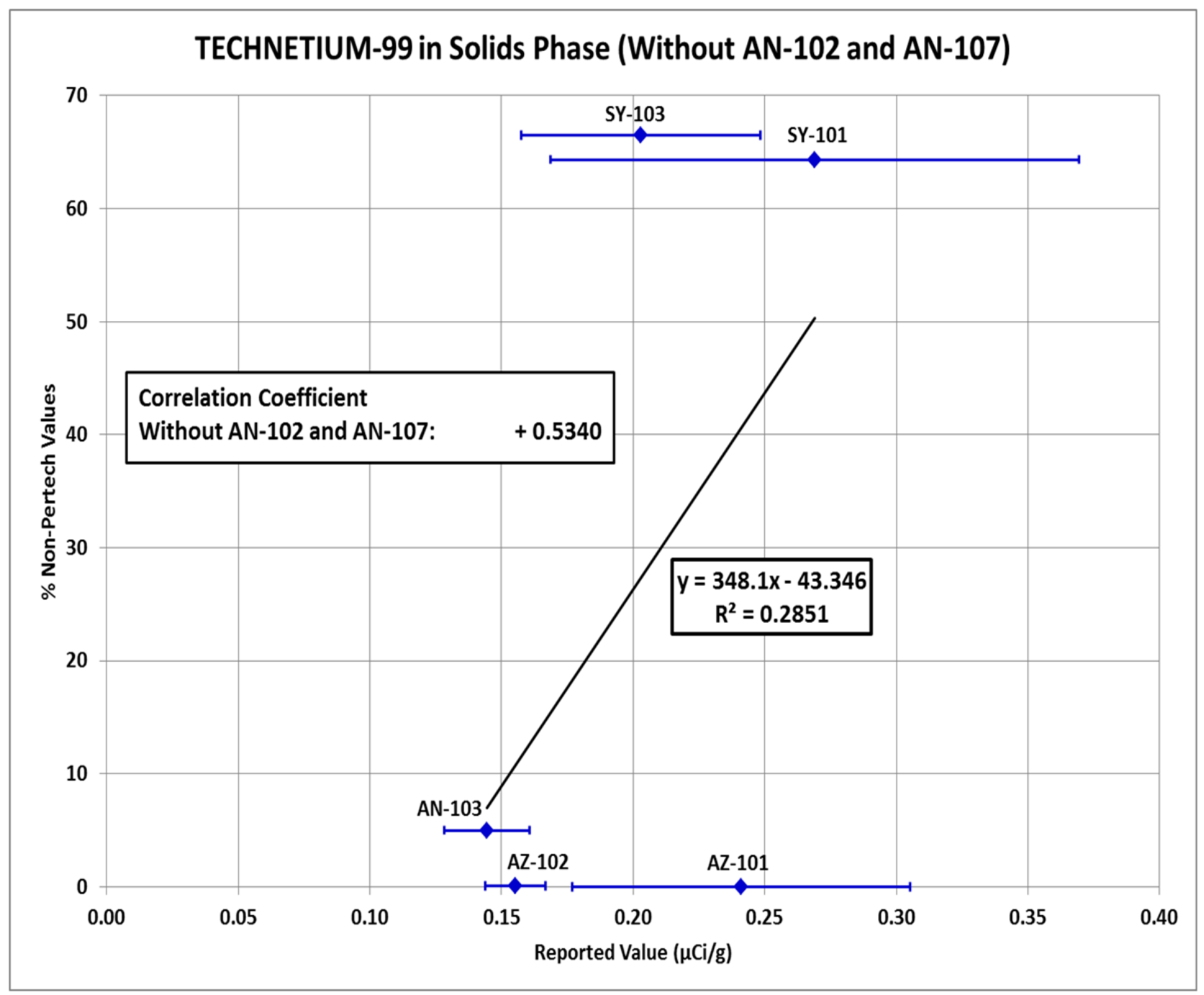

Figure A - 17: Techetium-99 - solids phase $(\mu \mathrm{Ci} / \mathrm{g})$ without tanks $\mathrm{AN}-102$ and $\mathrm{AN}-107$ 


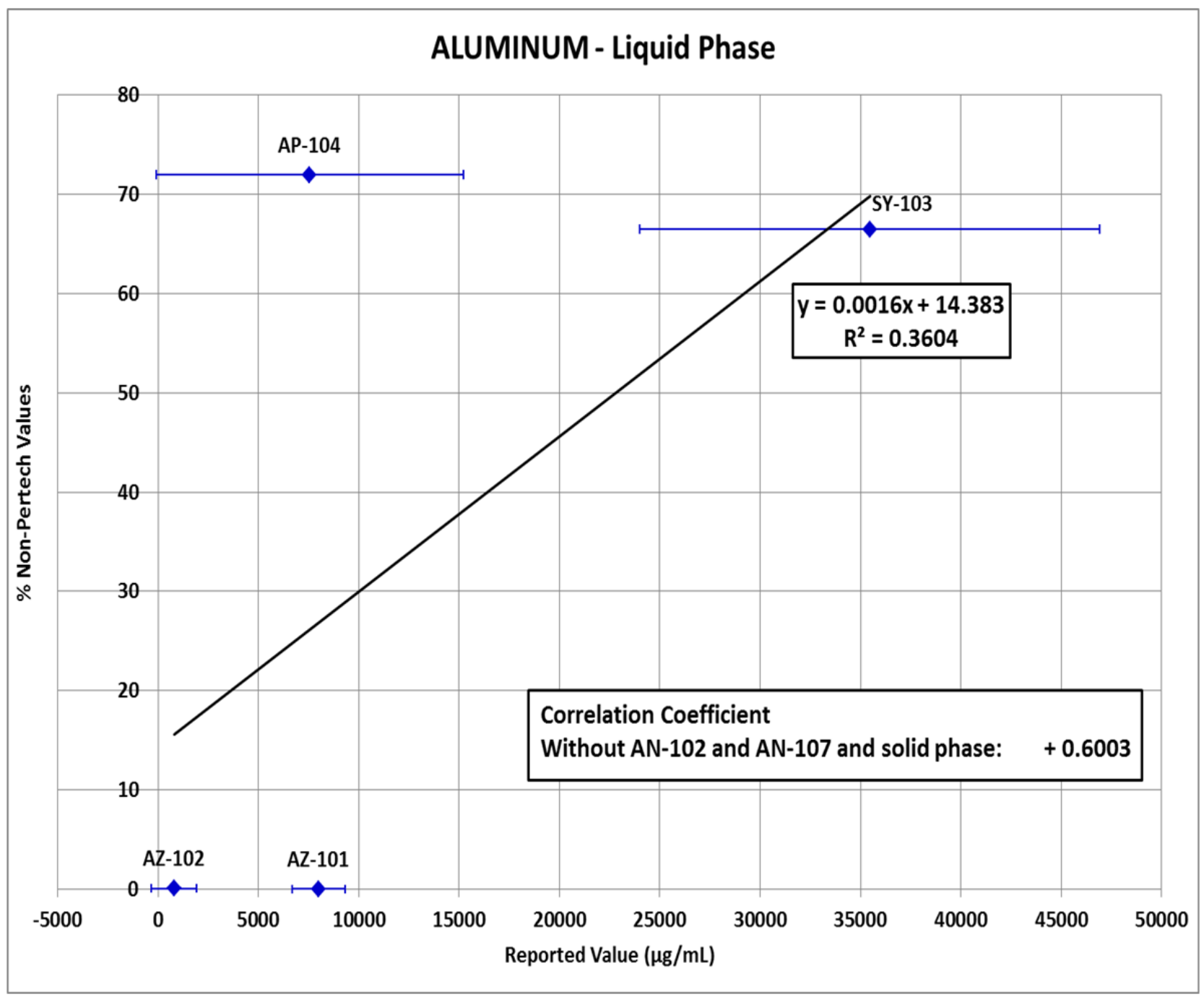

Figure A - 18: Soluble aluminum $(\mu \mathrm{g} / \mathrm{mL})$ 


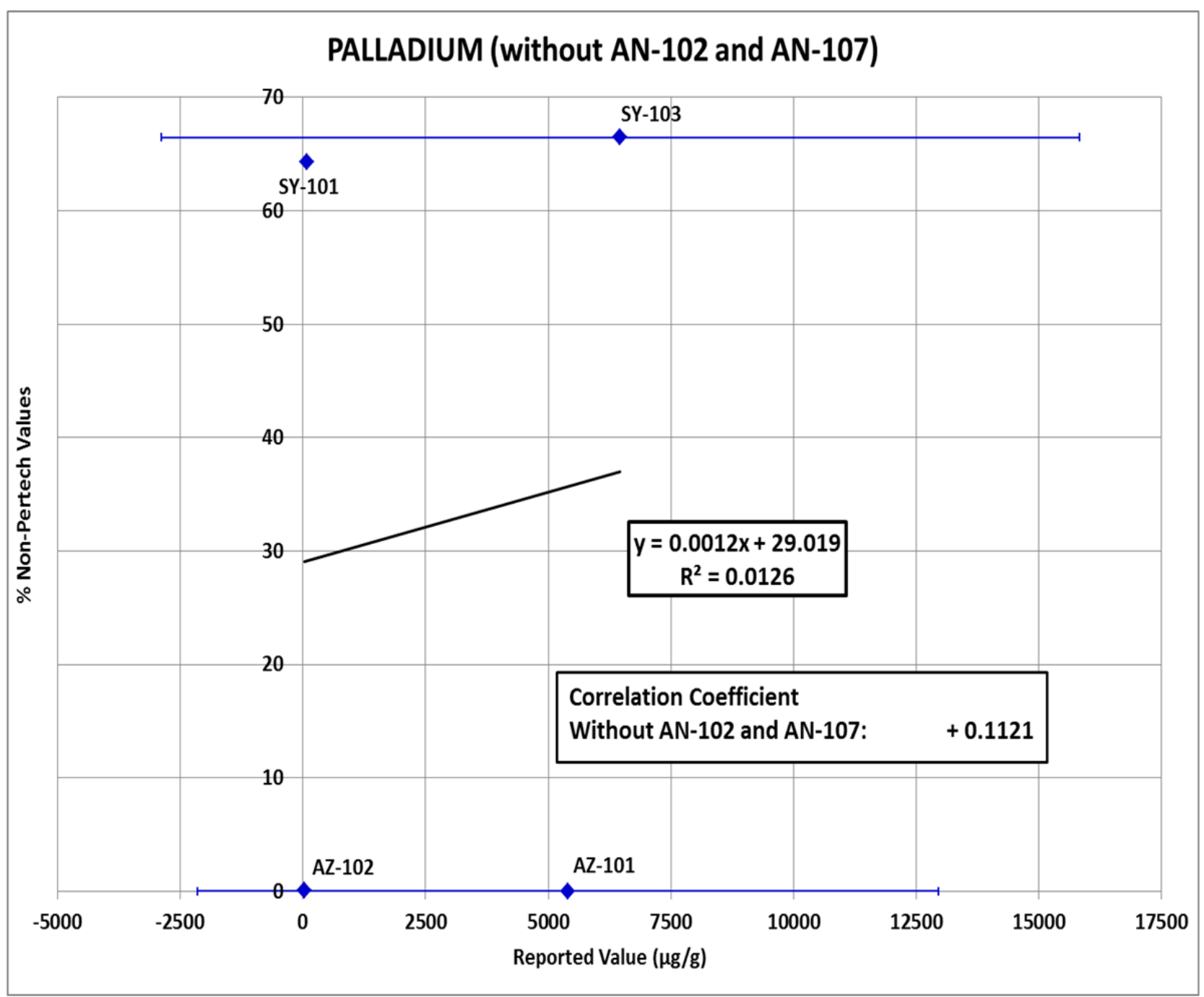

Figure A - 19: Noble metals in solid phase - palladium $(\mu \mathrm{g} / \mathrm{g})$ 


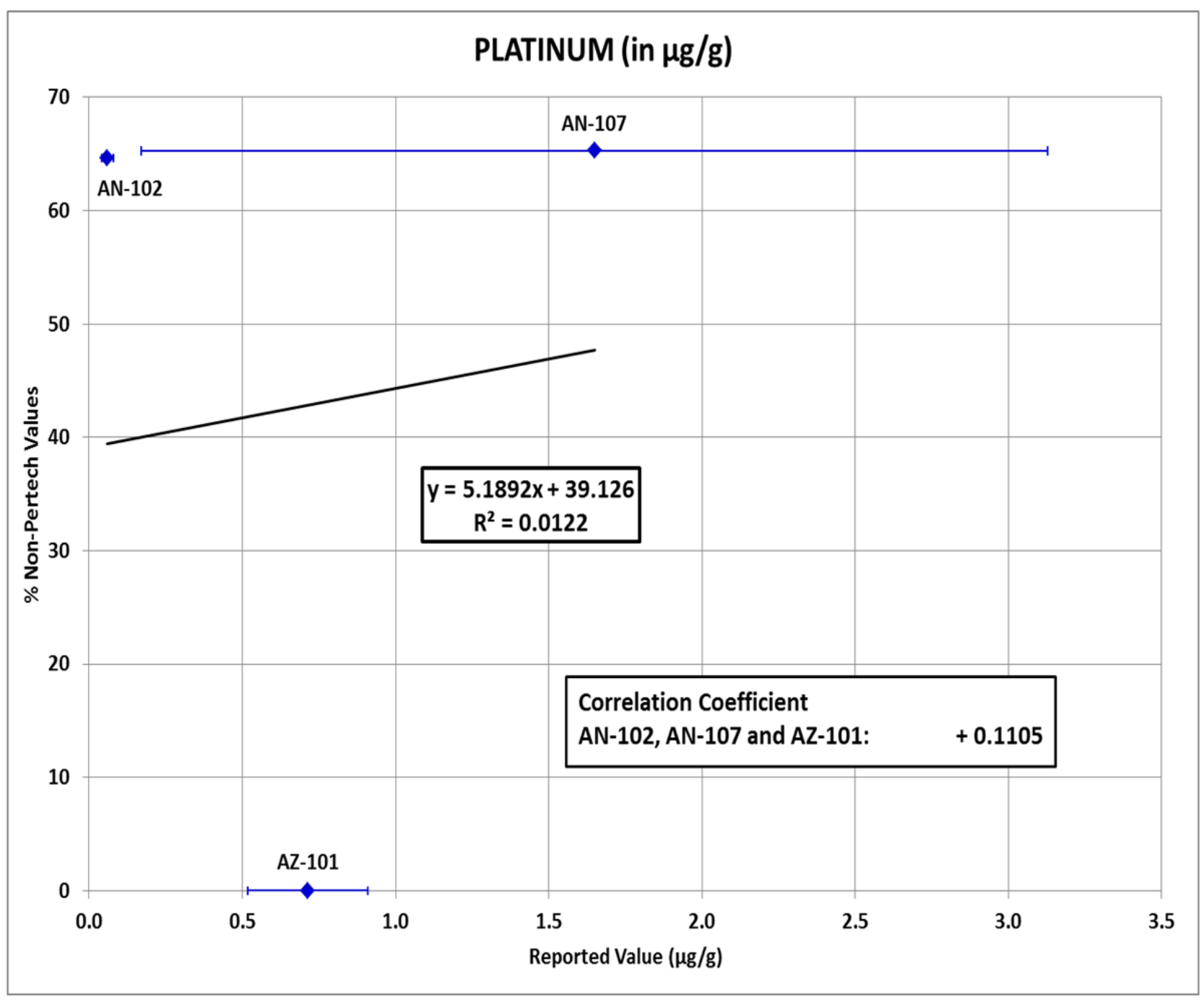

Figure A - 20: Noble metals in solid phase - platinum $(\mu \mathrm{g} / \mathrm{g})$ 


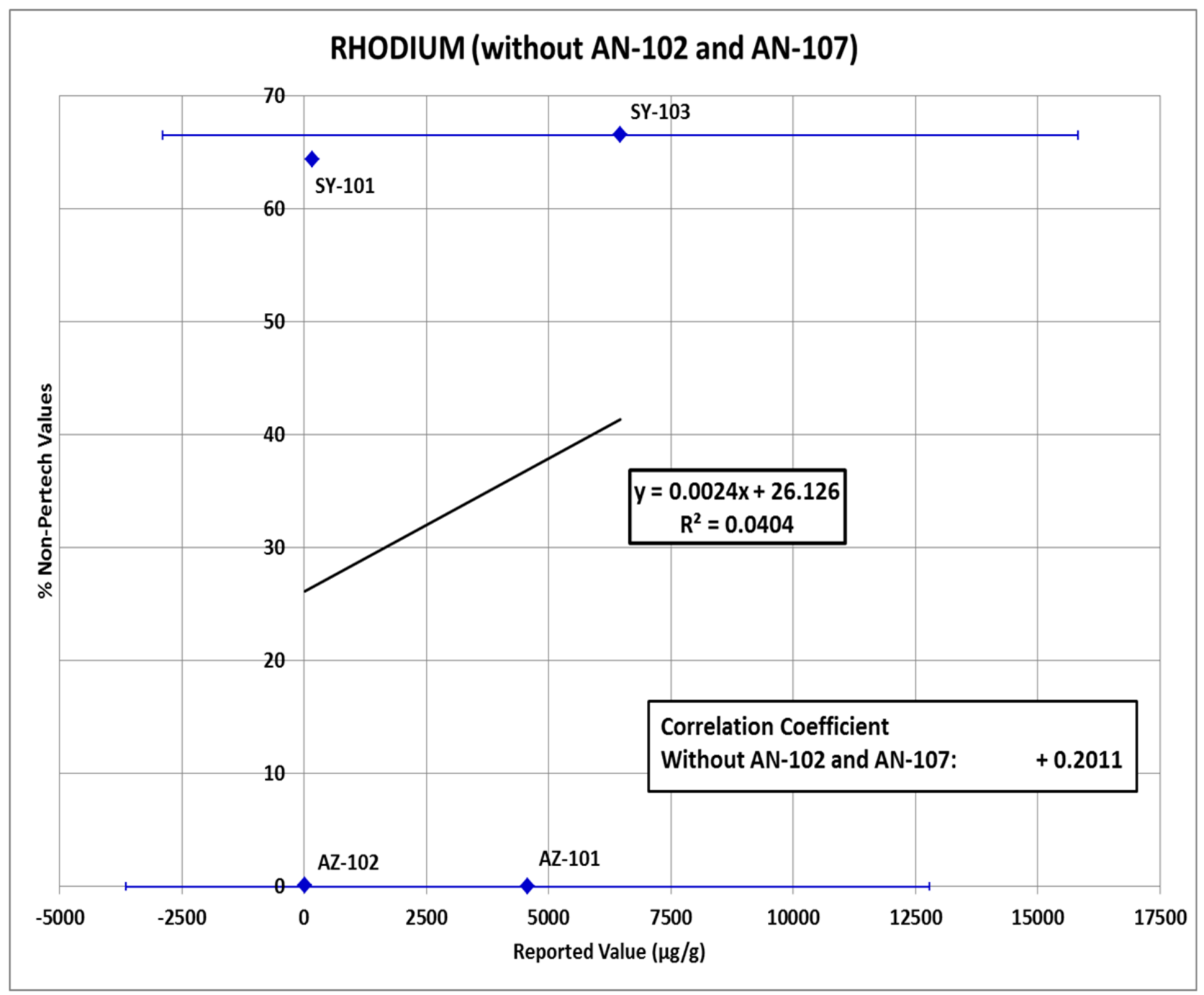

Figure A - 21: Noble metals in solid phase - rhodium $(\mu \mathrm{g} / \mathrm{g})$ 


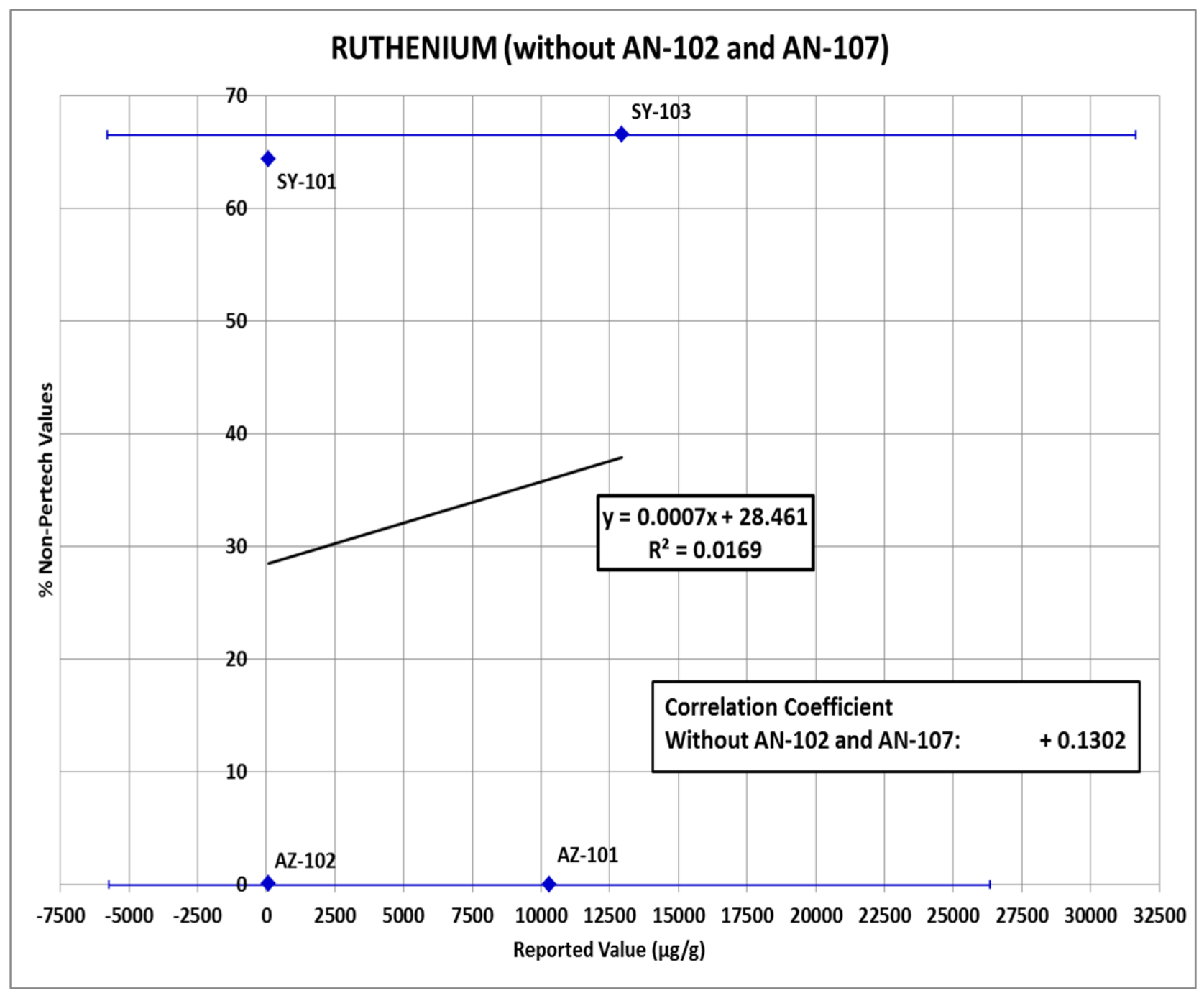

Figure A - 22: Noble metals in solid phases - ruthenium $(\mu \mathrm{g} / \mathrm{g})$ 


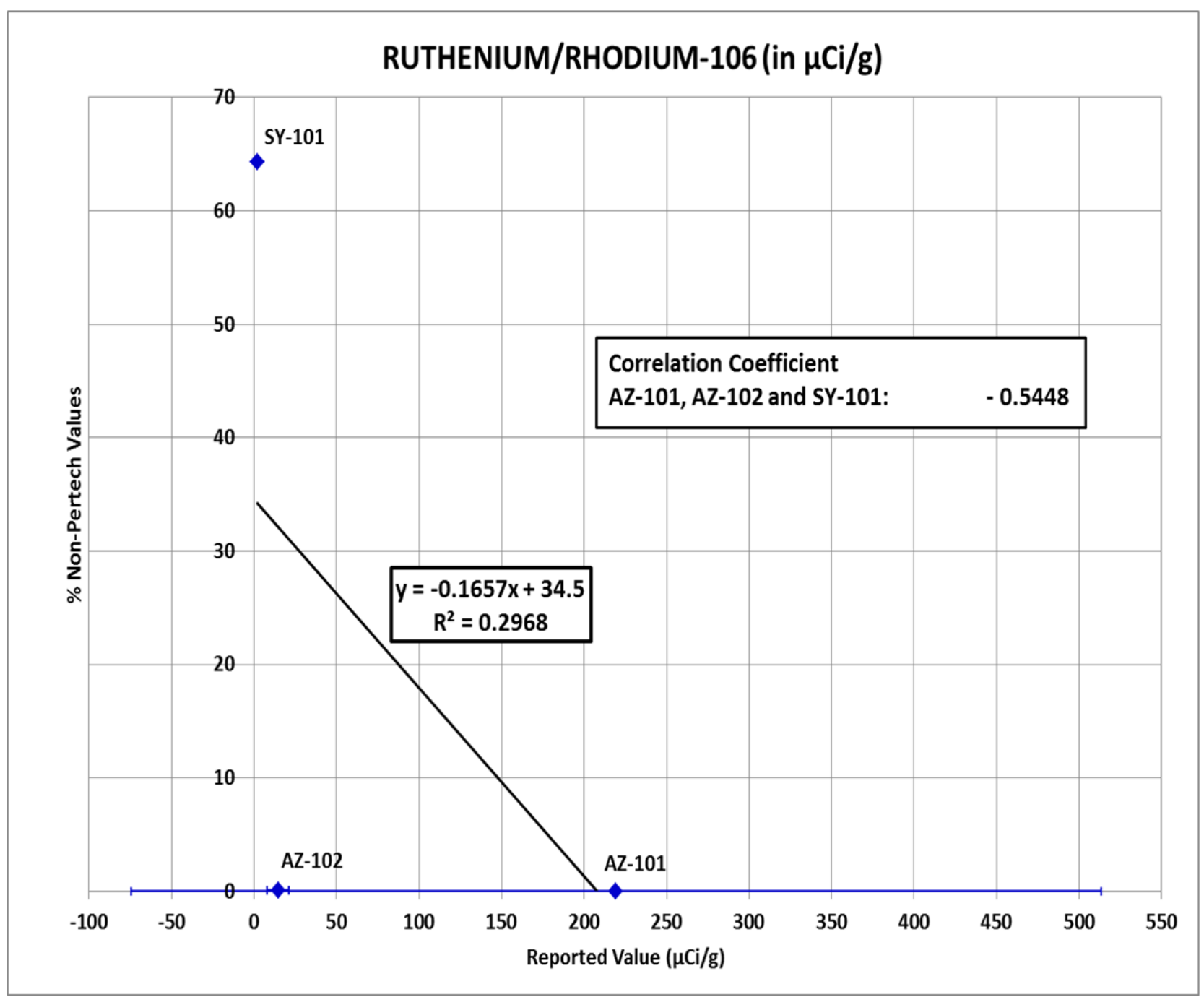

Figure A - 23: Noble metals in solid phases - ruthenium/rhodium-106 (Data in $\mu \mathrm{Ci} / \mathrm{g}$ ) 


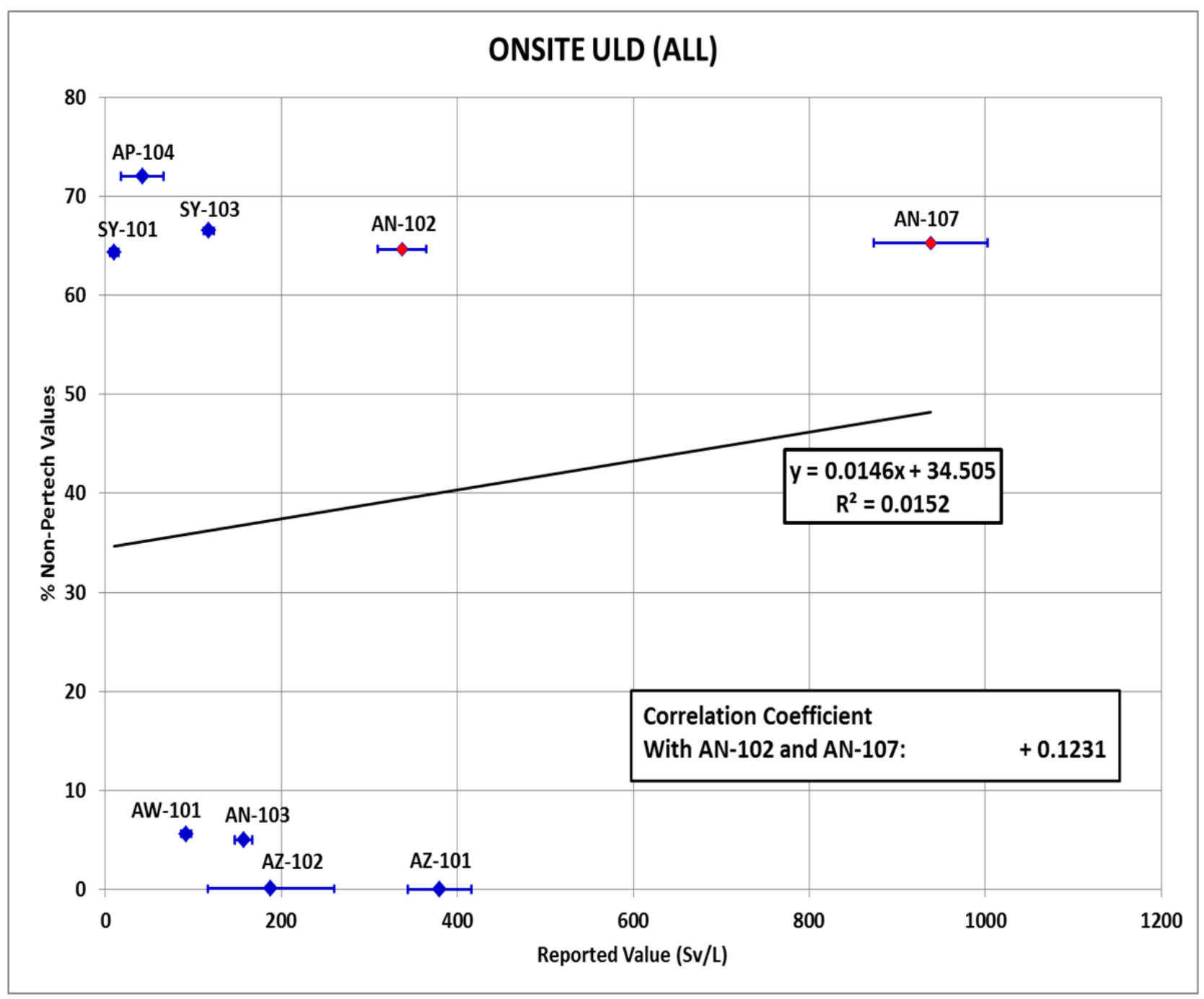

Figure A - 24: Unit liter dose (ULD) - all tanks of interest (in Sv/L) 


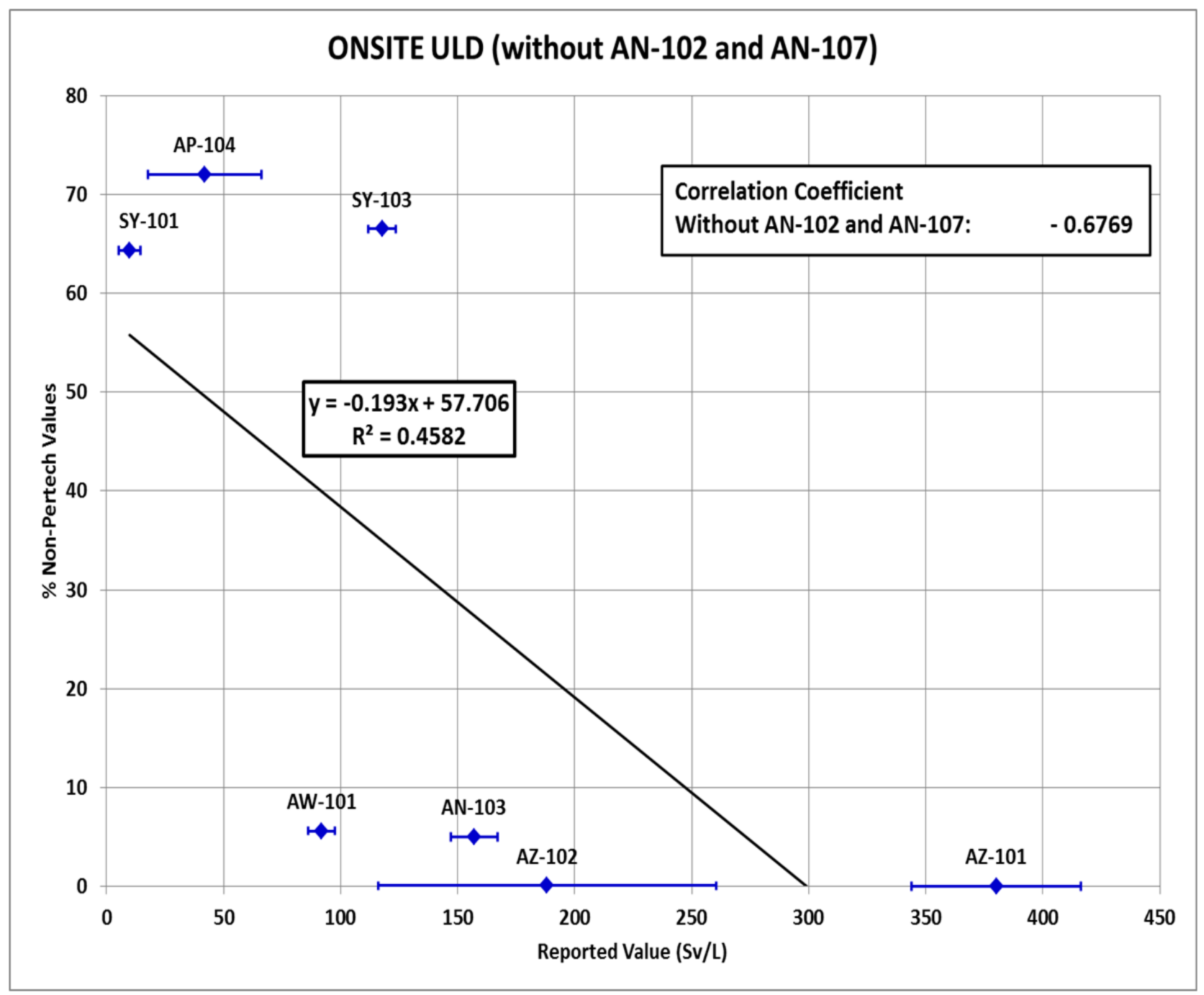

Figure A - 25: ULD without tanks AN-102 and AN-107 (in Sv/L) 


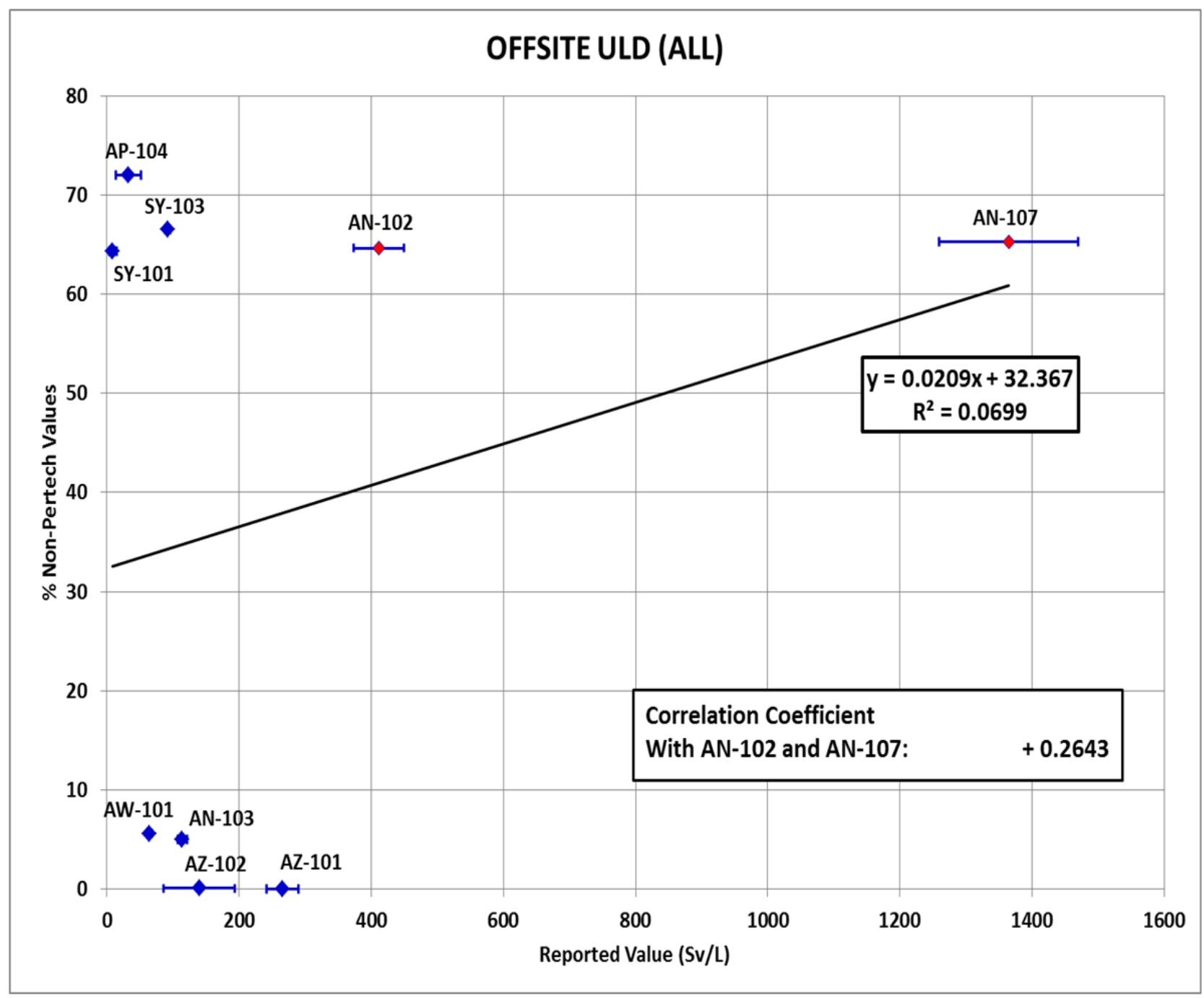

Figure A - 26: ULD, "offsite"- all tanks of interest (in Sv/L) 


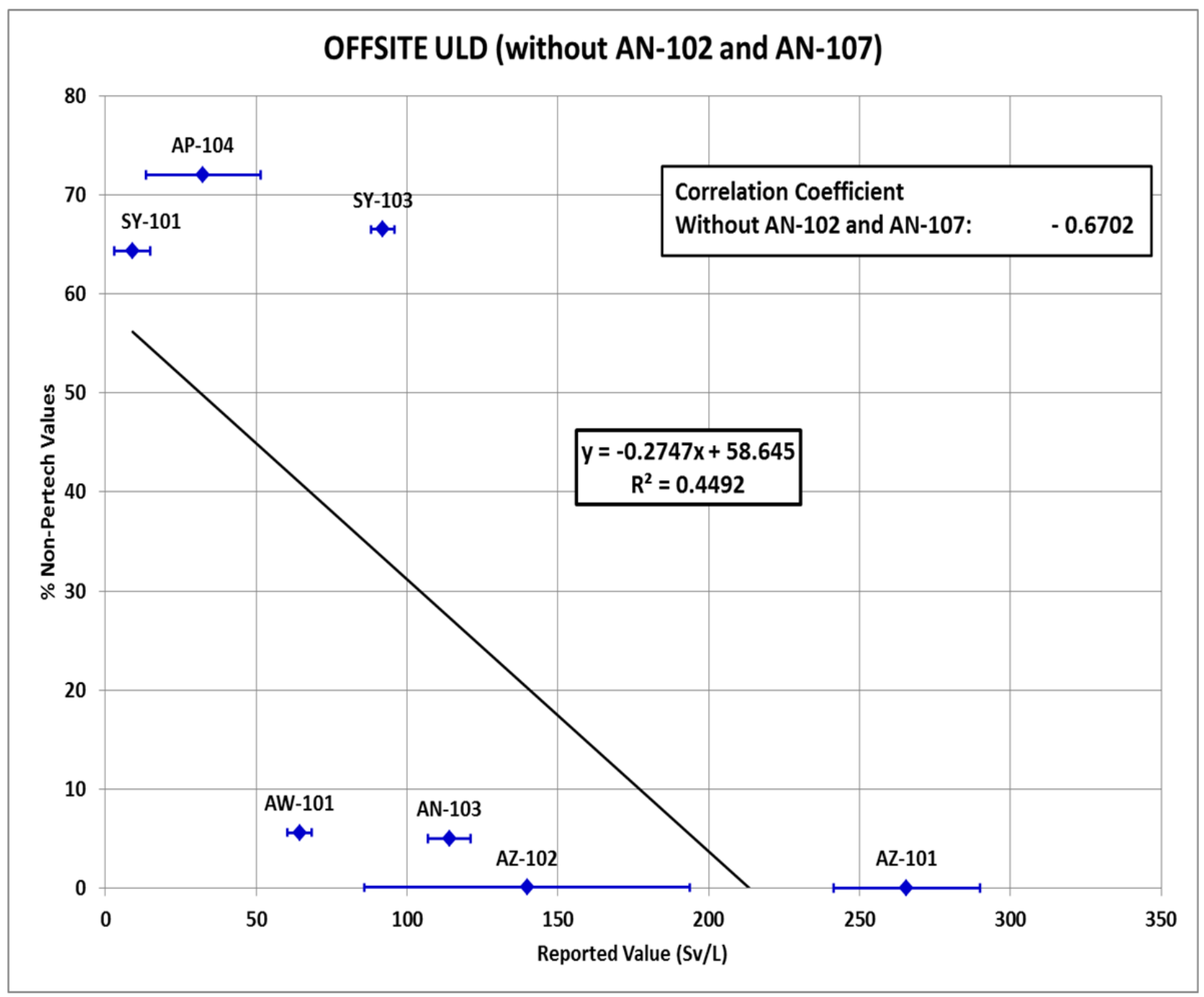

Figure A - 27: ULD, "offiste" without tanks AN-102 and AN-107 (Sv/L) 


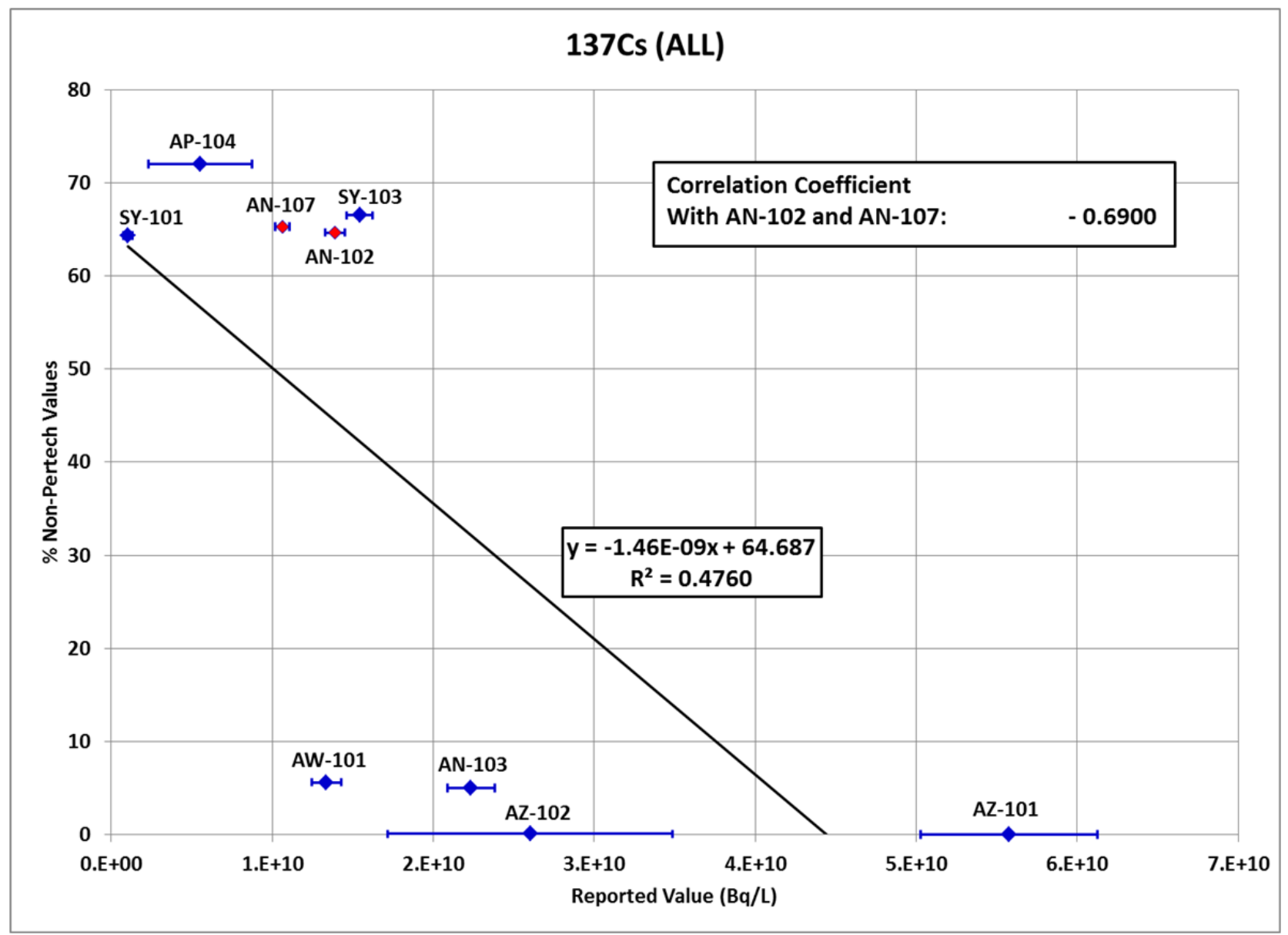

Figure A - 28: Dose from ${ }^{137} \mathrm{Cs}$ (in $\mathrm{Bq} / \mathrm{L}$ ) 


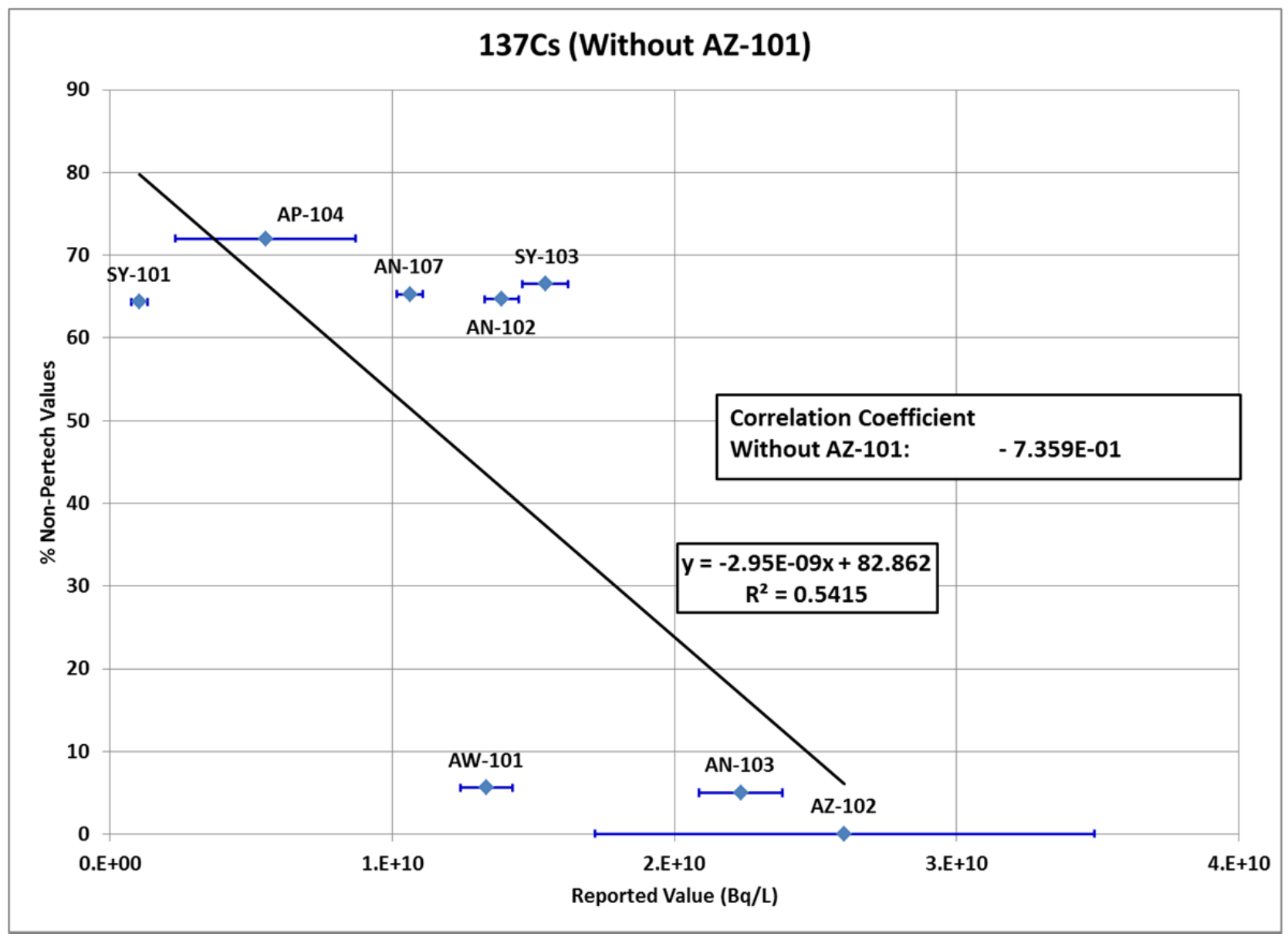

Figure A - 29: Dose from ${ }^{137} \mathrm{Cs}(\mathrm{Bq} / \mathrm{L})$ without tank $\mathrm{AZ}-101$ 


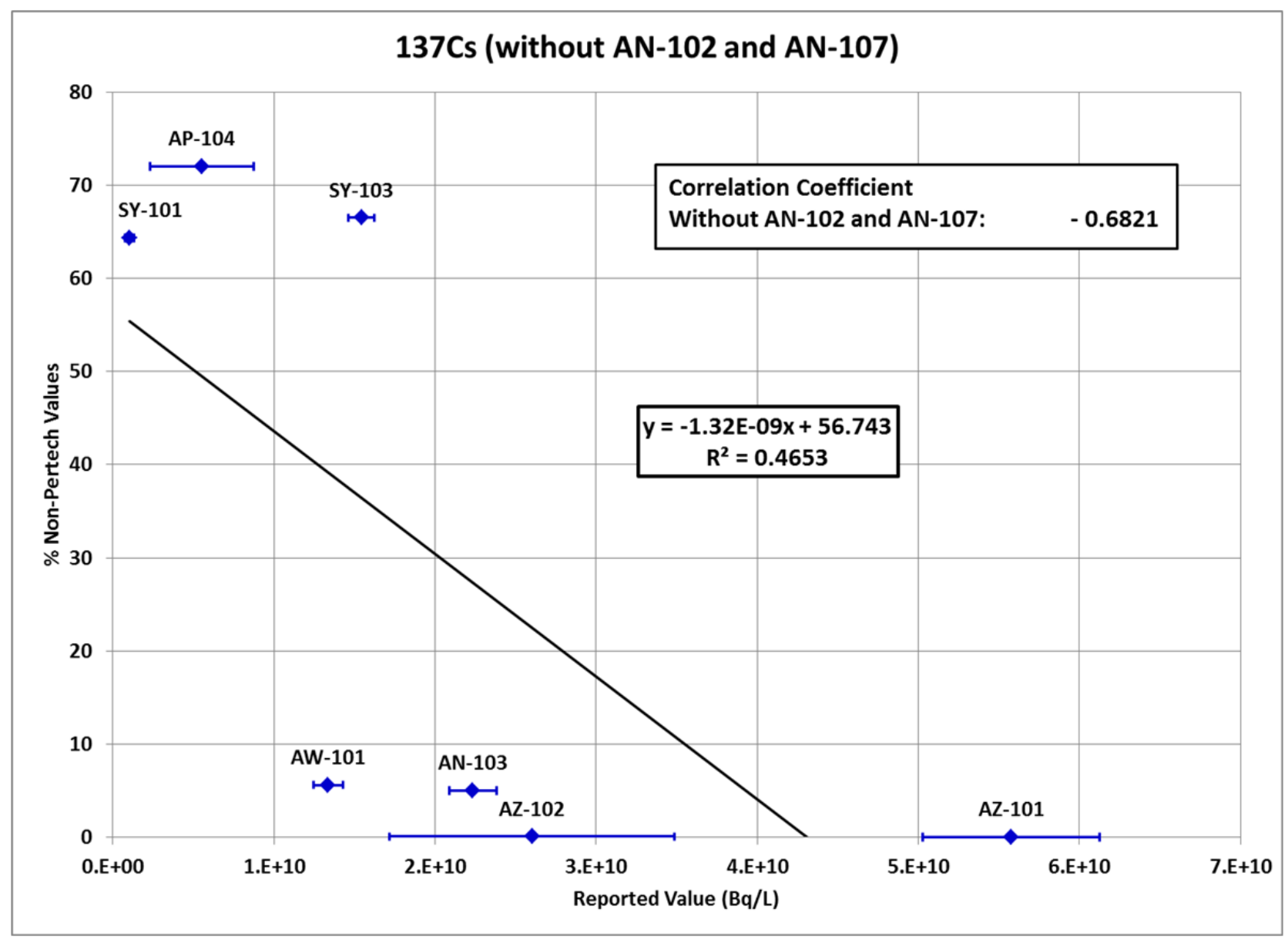

Figure A - 30: Dose from ${ }^{137} \mathrm{Cs}$ (in $\mathrm{Bq} / \mathrm{L}$ ) without tanks $\mathrm{AN}-102$ and $\mathrm{AN}-107$ 


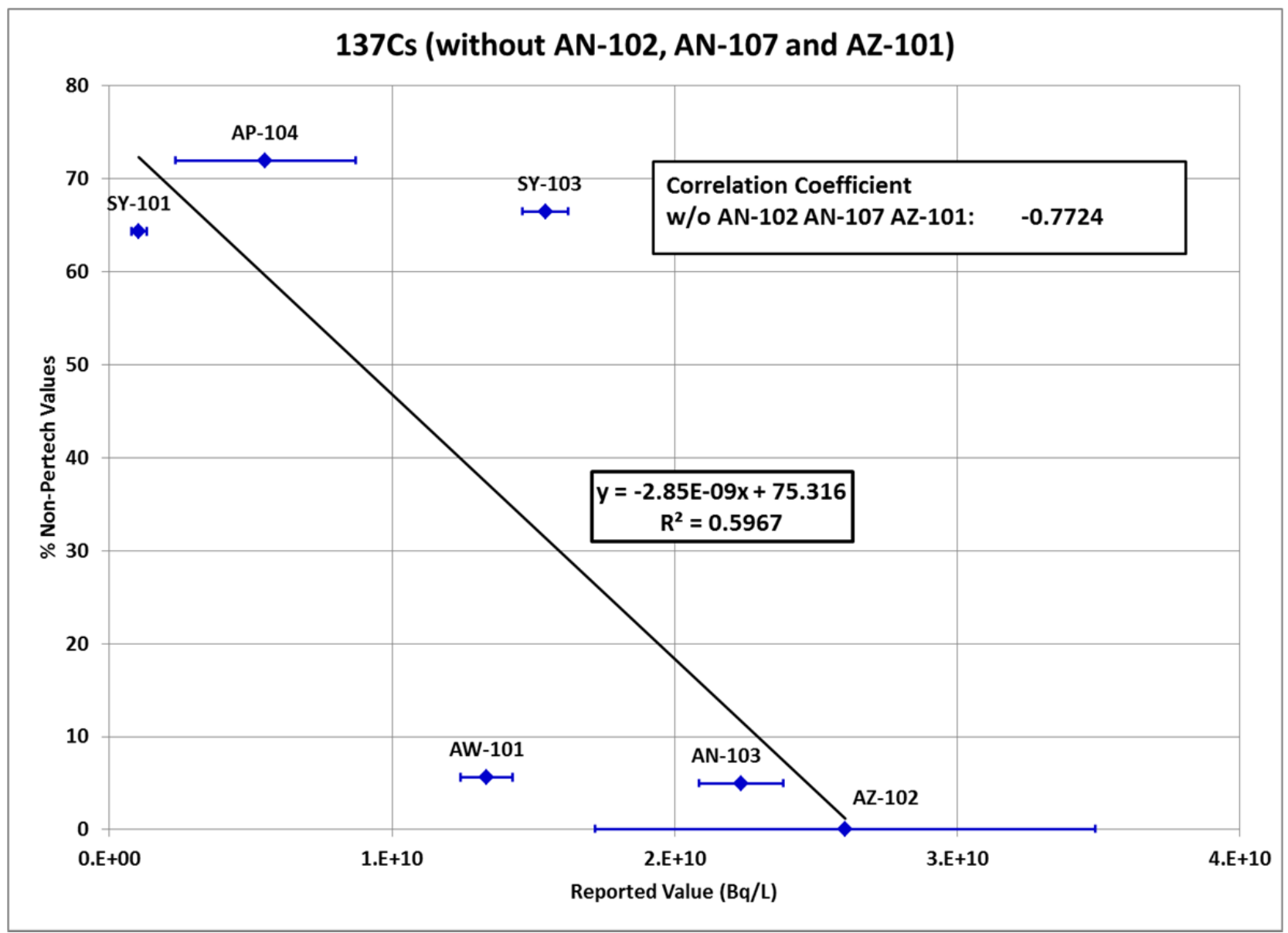

Figure A - 31: Dose from ${ }^{137} \mathrm{Cs}$ (in $\mathrm{Bq} / \mathrm{L}$ ) without tanks AN-102, AN-107, and AZ-101 


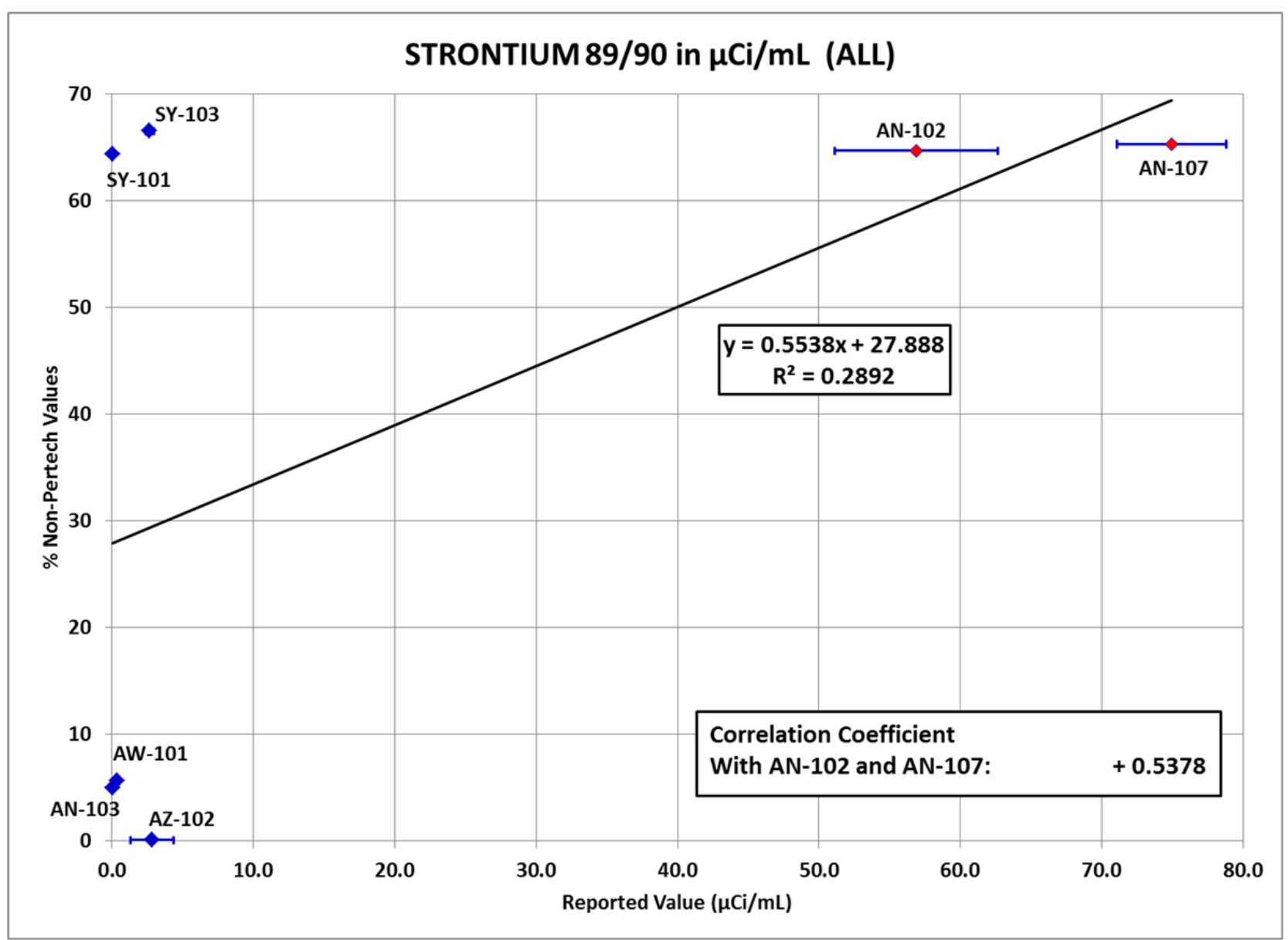

Figure A - 32: Dose from ${ }^{89 / 90} \mathrm{Sr}$, all tanks of interest (in $\mu \mathrm{Ci} / \mathrm{mL}$ ) 


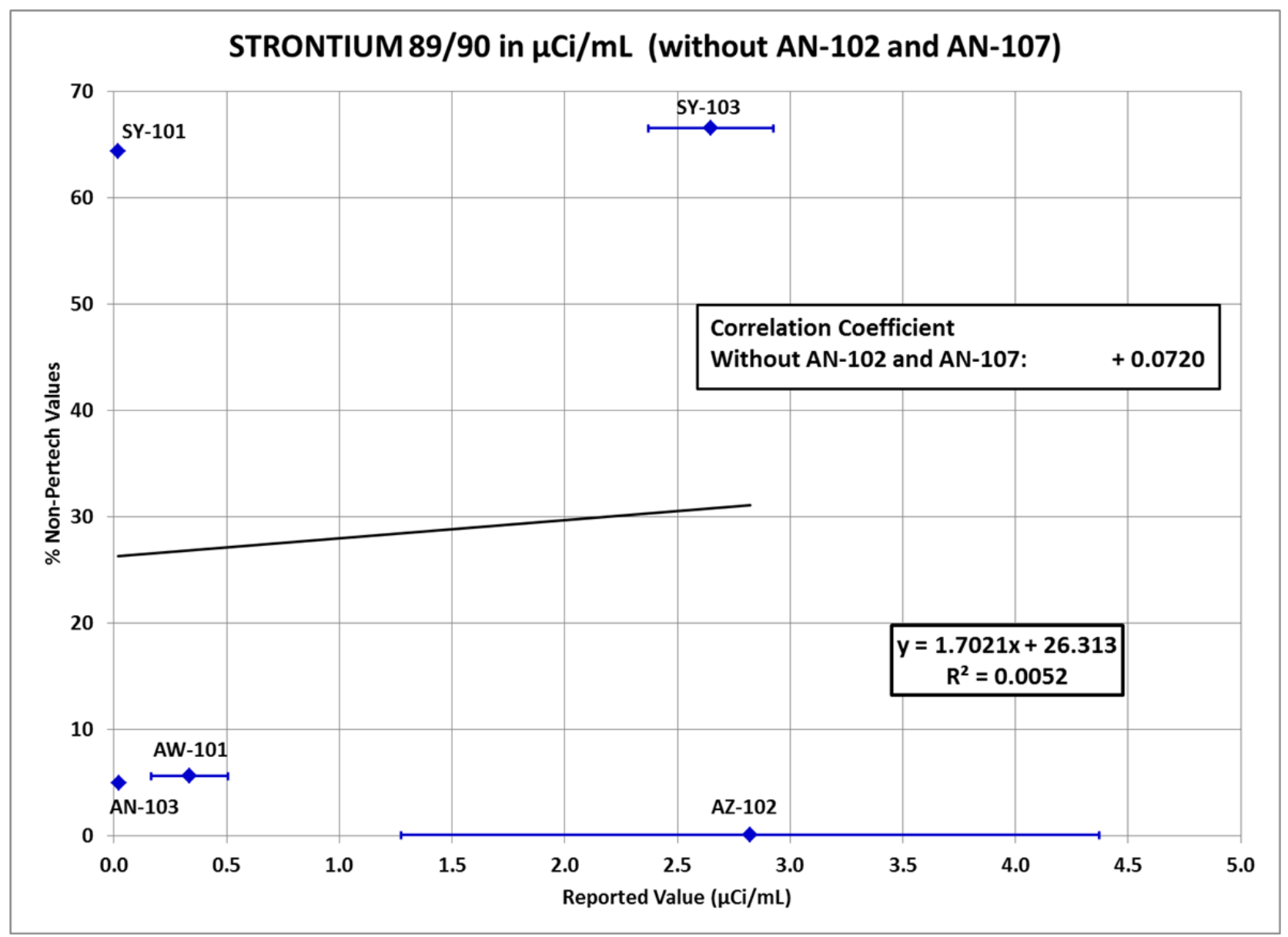

Figure A - 33: Dose from ${ }^{89 / 90} \mathrm{Sr}$ without tanks $\mathrm{AN}-102$ and $\mathrm{AN}-107(\mu \mathrm{Ci} / \mathrm{mL})$ 


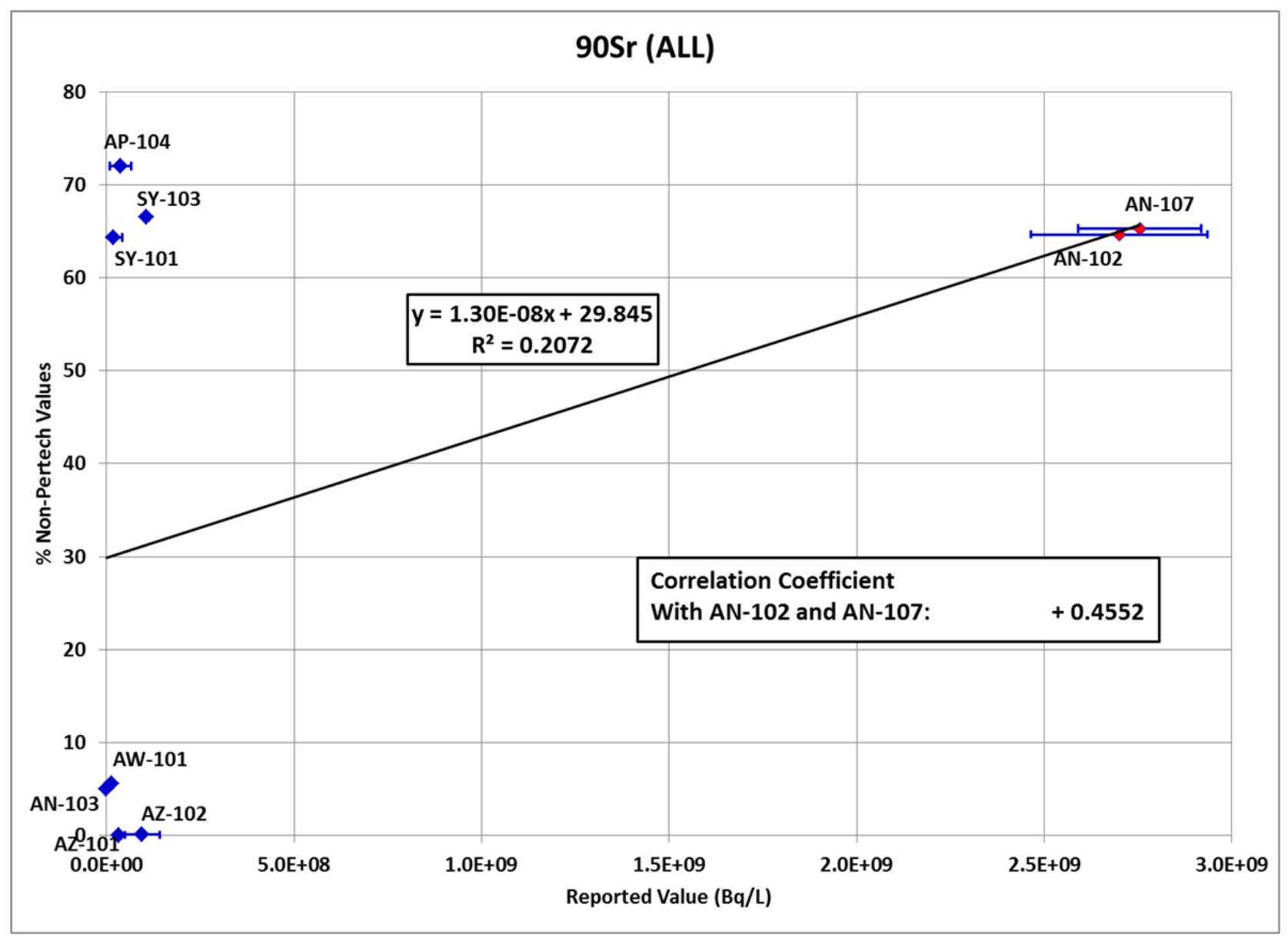

Figure A - 34: Dose from ${ }^{90} \mathrm{Sr}$, all tanks of interest (in $\mathrm{Bq} / \mathrm{L}$ ) 


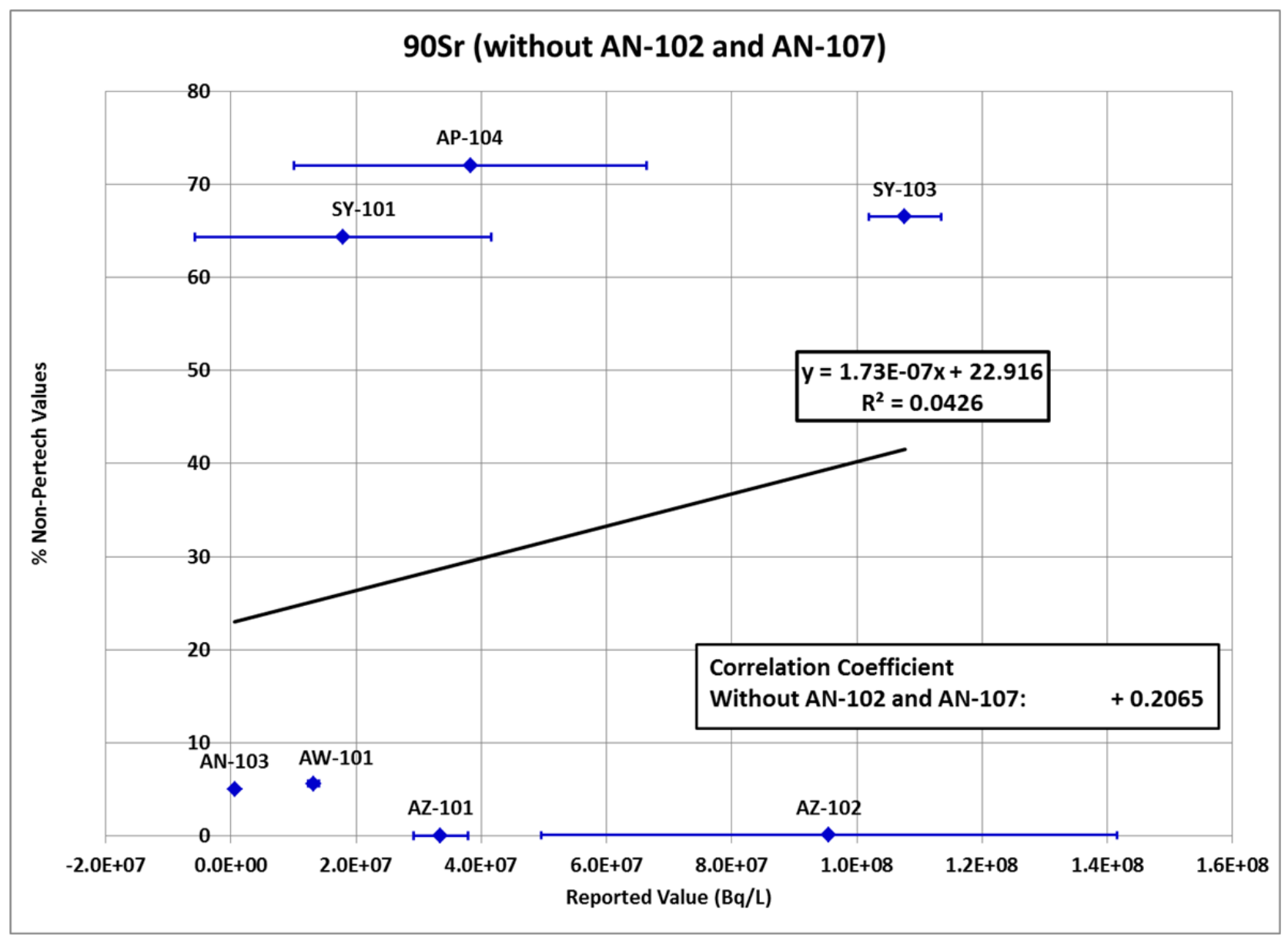

Figure A - 35: Dose from ${ }^{90} \mathrm{Sr}$ without tanks $\mathrm{AN}-102$ and $\mathrm{AN}-107$ (in $\left.\mathrm{Bq} / \mathrm{L}\right)$ 


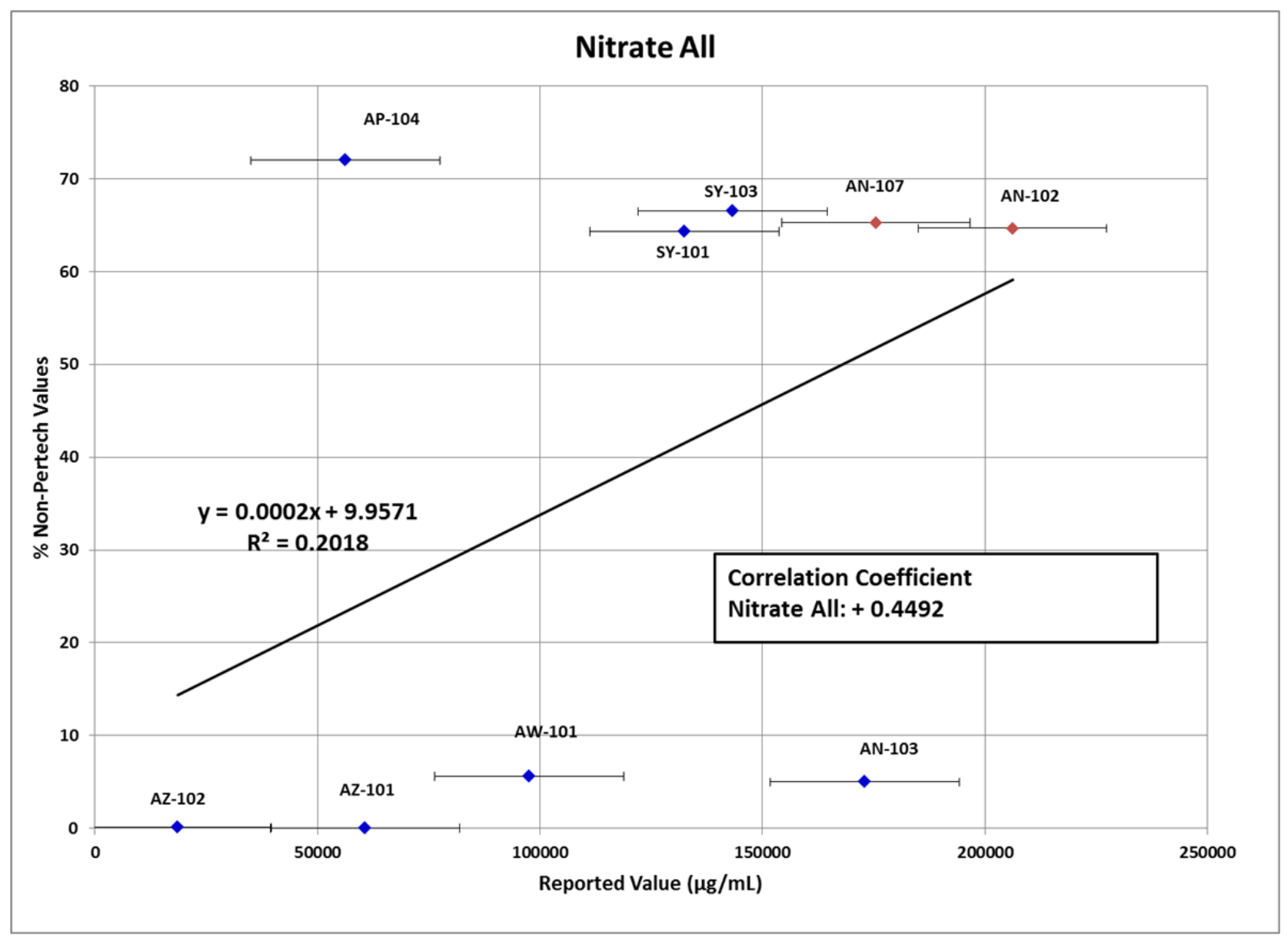

Figure A - 36: Nitrate (all tanks; data in $\mu \mathrm{g} / \mathrm{mL}$ ) 


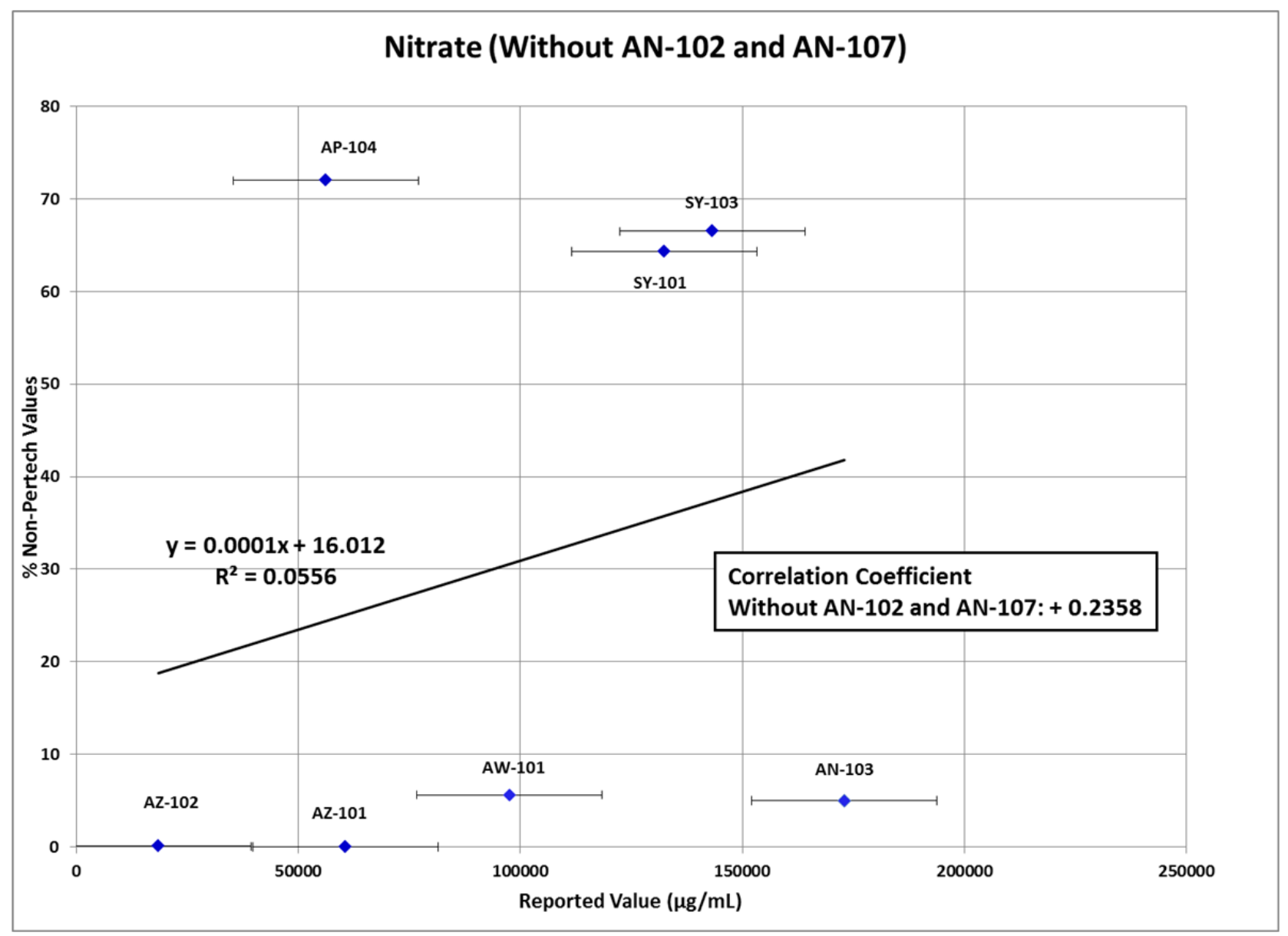

Figure A - 37: Nitrate without tanks AN-102 and AN-107 (in $\mu \mathrm{g} / \mathrm{mL}$ ) 


\section{Appendix B: Table of calculated rates of pertechnetate reduction in Hanford tanks based on the model described in Section $\mathbf{3 . 0}$}

Table B - 1: Summary of the Rates of Pertechnetate Reduction as Calculated by the Equations Described in the Text

\begin{tabular}{|c|c|c|}
\hline$\#$ & Rate $\left(\mathrm{M}^{-1} \mathrm{~s}^{-1}\right)$ & Reaction \\
\hline 1 & $1.40 \mathrm{E}+11$ & $\mathrm{H}^{+}+\mathrm{OH}^{-}=\mathrm{H}_{2} \mathrm{O}$ \\
\hline 2 & $1.40 \mathrm{E}-03$ & $\mathrm{H}_{2} \mathrm{O}=\mathrm{H}^{+}+\mathrm{OH}^{-}$ \\
\hline 3 & $1.12 \mathrm{E}-01$ & $\mathrm{H}_{2} \mathrm{O}_{2}=\mathrm{H}^{+}+\mathrm{HO}_{2}^{-}$ \\
\hline 4 & $5.00 E+10$ & $\mathrm{H}^{+}+\mathrm{HO}_{2}^{-}=\mathrm{H}_{2} \mathrm{O}_{2}$ \\
\hline 5 & $1.30 \mathrm{E}+10$ & $\mathrm{H}_{2} \mathrm{O}_{2}+\mathrm{OH}^{-}=\mathrm{HO}_{2}^{-}+\mathrm{H}_{2} \mathrm{O}$ \\
\hline 6 & $5.82 \mathrm{E}+07$ & $\mathrm{HO}_{2}^{-}+\mathrm{H}_{2} \mathrm{O}=\mathrm{H}_{2} \mathrm{O}_{2}+\mathrm{OH}^{-}$ \\
\hline 7 & $1.90 \mathrm{E}+01$ & $\mathrm{e}^{-}+\mathrm{H}_{2} \mathrm{O}=\mathrm{H}+\mathrm{OH}^{-}$ \\
\hline 8 & $2.20 E+07$ & $\mathrm{H}+\mathrm{OH}^{-}=\mathrm{e}^{-}+\mathrm{H}_{2} \mathrm{O}$ \\
\hline 9 & $3.91 E+00$ & $\mathrm{H}=\mathrm{e}^{-}+\mathrm{H}^{+}$ \\
\hline 10 & $2.30 \mathrm{E}+10$ & $\mathrm{e}^{-}+\mathrm{H}^{+}=\mathrm{H}$ \\
\hline 11 & $1.30 \mathrm{E}+10$ & $\mathrm{OH}+\mathrm{OH}^{-}=\mathrm{O}^{-}+\mathrm{H}_{2} \mathrm{O}$ \\
\hline 12 & $1.04 \mathrm{E}+08$ & $\mathrm{O}^{-}+\mathrm{H}_{2} \mathrm{O}=\mathrm{OH}+\mathrm{OH}^{-}$ \\
\hline 13 & $1.26 \mathrm{E}-01$ & $\mathrm{OH}=\mathrm{O}^{-}+\mathrm{H}^{+}$ \\
\hline 14 & $1.00 \mathrm{E}+11$ & $\mathrm{O}^{-}+\mathrm{H}^{+}=\mathrm{OH}$ \\
\hline 15 & $1.35 E+06$ & $\mathrm{HO}_{2}=\mathrm{O}_{2}^{-}+\mathrm{H}^{+}$ \\
\hline 16 & $5.00 \mathrm{E}+10$ & $\mathrm{O}_{2}^{-}+\mathrm{H}^{+}=\mathrm{HO}_{2}$ \\
\hline 17 & $5.00 \mathrm{E}+10$ & $\mathrm{HO}_{2}+\mathrm{OH}^{-}=\mathrm{O}_{2}^{-}+\mathrm{H}_{2} \mathrm{O}$ \\
\hline 18 & $1.86 \mathrm{E}+01$ & $\mathrm{O}_{2}^{-}+\mathrm{H}_{2} \mathrm{O}=\mathrm{HO}_{2}+\mathrm{OH}^{-}$ \\
\hline 19 & $3.0 \mathrm{E}+10$ & $\mathrm{e}^{-}+\mathrm{OH}=\mathrm{OH}^{-}$ \\
\hline 20 & $1.1 \mathrm{E}+10$ & $\mathrm{e}^{-}+\mathrm{H}_{2} \mathrm{O}_{2}=\mathrm{OH}+\mathrm{OH}^{-}$ \\
\hline 21 & $1.3 \mathrm{E}+10$ & $\mathrm{e}^{-}+\mathrm{O}_{2}^{-}+\mathrm{H}_{2} \mathrm{O}=\mathrm{HO}_{2}^{-}+\mathrm{OH}^{-}$ \\
\hline 22 & $2.0 \mathrm{E}+10$ & $\mathrm{e}^{-}+\mathrm{HO}_{2}=\mathrm{HO}_{2}^{-}$ \\
\hline 23 & $1.9 \mathrm{E}+10$ & $\mathrm{e}^{-}+\mathrm{O}_{2}=\mathrm{O}_{2}^{-}$ \\
\hline
\end{tabular}




\begin{tabular}{|c|c|c|}
\hline$\#$ & Rate $\left(\mathrm{M}^{-1} \mathrm{~s}^{-1}\right)$ & Reaction \\
\hline 24 & $5.5 E+09$ & $\mathrm{e}^{-}+\mathrm{e}^{-}+\mathrm{H}_{2} \mathrm{O}+\mathrm{H}_{2} \mathrm{O}=\mathrm{H}_{2}+\mathrm{OH}^{-}+\mathrm{O}+\mathrm{H}^{-}$ \\
\hline 25 & $2.5 \mathrm{E}+10$ & $\mathrm{e}^{-}+\mathrm{H}+\mathrm{H}_{2} \mathrm{O}=\mathrm{H}_{2}+\mathrm{OH}^{-}$ \\
\hline 26 & $3.5 \mathrm{E}+09$ & $\mathrm{e}^{-}+\mathrm{HO}_{2}^{-}=\mathrm{O}^{-}+\mathrm{OH}^{-}$ \\
\hline 27 & $2.2 \mathrm{E}+10$ & $\mathrm{e}^{-}+\mathrm{O}^{-}+\mathrm{H}_{2} \mathrm{O}=\mathrm{OH}^{-}+\mathrm{OH}^{-}$ \\
\hline 28 & $1.6 \mathrm{E}+10$ & $\mathrm{e}^{-}+\mathrm{O}_{3}^{-}+\mathrm{H}_{2} \mathrm{O}=\mathrm{O}_{2}+\mathrm{OH}^{-}+\mathrm{OH}^{-}$ \\
\hline 29 & $3.6 \mathrm{E}+10$ & $\mathrm{e}^{-}+\mathrm{O}_{3}=\mathrm{O}_{3}^{-}$ \\
\hline 30 & $1.1 \mathrm{E}+01$ & $\mathrm{H}+\mathrm{H}_{2} \mathrm{O}=\mathrm{H}_{2}+\mathrm{OH}$ \\
\hline 31 & $1.0 \mathrm{E}+10$ & $\mathrm{H}+\mathrm{O}^{-}=\mathrm{OH}^{-}$ \\
\hline 32 & $9.0 \mathrm{E}+07$ & $\mathrm{H}+\mathrm{HO}_{2}^{-}=\mathrm{OH}+\mathrm{OH}^{-}$ \\
\hline 33 & $1.0 \mathrm{E}+10$ & $\mathrm{H}+\mathrm{O}_{3}^{-}=\mathrm{OH}^{-}+\mathrm{O}_{2}$ \\
\hline 34 & $7.8 \mathrm{E}+09$ & $\mathrm{H}+\mathrm{H}=\mathrm{H}_{2}$ \\
\hline 35 & $7.0 \mathrm{E}+09$ & $\mathrm{H}+\mathrm{OH}=\mathrm{H}_{2} \mathrm{O}$ \\
\hline 36 & $9.0 \mathrm{E}+07$ & $\mathrm{H}+\mathrm{H}_{2} \mathrm{O}_{2}=\mathrm{OH}+\mathrm{H}_{2} \mathrm{O}$ \\
\hline 37 & $2.1 \mathrm{E}+10$ & $\mathrm{H}+\mathrm{O}_{2}=\mathrm{HO}_{2}$ \\
\hline 38 & $1.8 \mathrm{E}+10$ & $\mathrm{H}+\mathrm{HO}_{2}=\mathrm{H}_{2} \mathrm{O}_{2}$ \\
\hline 39 & $1.8 \mathrm{E}+10$ & $\mathrm{H}+\mathrm{O}_{2}^{-}=\mathrm{HO}_{2}^{-}$ \\
\hline 40 & $3.8 \mathrm{E}+10$ & $\mathrm{H}+\mathrm{O}_{3}=\mathrm{HO}_{3}$ \\
\hline 41 & $3.6 \mathrm{E}+09$ & $\mathrm{OH}+\mathrm{OH}=\mathrm{H}_{2} \mathrm{O}_{2}$ \\
\hline 42 & $6.0 \mathrm{E}+09$ & $\mathrm{OH}+\mathrm{HO}_{2}=\mathrm{H}_{2} \mathrm{O}+\mathrm{O}_{2}$ \\
\hline 43 & $8.2 E+09$ & $\mathrm{OH}+\mathrm{O}_{2}^{-}=\mathrm{OH}^{-}+\mathrm{O}_{2}$ \\
\hline 44 & $4.3 \mathrm{E}+07$ & $\mathrm{OH}+\mathrm{H}_{2}=\mathrm{H}+\mathrm{H}_{2} \mathrm{O}$ \\
\hline 45 & $2.7 \mathrm{E}+07$ & $\mathrm{OH}+\mathrm{H}_{2} \mathrm{O}_{2}=\mathrm{HO}_{2}+\mathrm{H}_{2} \mathrm{O}$ \\
\hline 46 & $2.5 E+10$ & $\mathrm{OH}+\mathrm{O}^{-}=\mathrm{HO}_{2}^{-}$ \\
\hline 47 & $7.5 \mathrm{E}+09$ & $\mathrm{OH}+\mathrm{HO}_{2}^{-}=\mathrm{HO}_{2}+\mathrm{OH}^{-}$ \\
\hline 48 & $2.6 \mathrm{E}+09$ & $\mathrm{OH}+\mathrm{O}_{3}^{-}=\mathrm{O}_{3}+\mathrm{OH}^{-}$ \\
\hline 49 & $6.0 \mathrm{E}+09$ & $\mathrm{OH}+\mathrm{O}_{3}^{-}=\mathrm{O}_{2}^{-}+\mathrm{O}_{2}^{-}+\mathrm{H}^{+}$ \\
\hline 50 & $1.1 \mathrm{E}+08$ & $\mathrm{OH}+\mathrm{O}_{3}=\mathrm{HO}_{2}+\mathrm{O}_{2}$ \\
\hline 51 & $8.0 E+07$ & $\mathrm{HO}_{2}+\mathrm{O}_{2}^{-}=\mathrm{HO}_{2}^{-}+\mathrm{O}_{2}$ \\
\hline
\end{tabular}




\begin{tabular}{|c|c|c|}
\hline$\#$ & Rate $\left(\mathrm{M}^{-1} \mathrm{~s}^{-1}\right)$ & Reaction \\
\hline 52 & $7.0 \mathrm{E}+05$ & $\mathrm{HO}_{2}+\mathrm{HO}_{2}=\mathrm{H}_{2} \mathrm{O}_{2}+\mathrm{O}_{2}$ \\
\hline 53 & $6.0 E+09$ & $\mathrm{HO}_{2}+\mathrm{O}^{-}=\mathrm{O}_{2}+\mathrm{OH}^{-}$ \\
\hline 54 & $5.0 \mathrm{E}-01$ & $\mathrm{HO}_{2}+\mathrm{H}_{2} \mathrm{O}_{2}=\mathrm{OH}+\mathrm{O}_{2}+\mathrm{H}_{2} \mathrm{O}$ \\
\hline 55 & 5.0E-01 & $\mathrm{HO}_{2}+\mathrm{HO}_{2}^{-}=\mathrm{OH}+\mathrm{O}_{2}+\mathrm{OH}^{-}$ \\
\hline 56 & $6.0 \mathrm{E}+09$ & $\mathrm{HO}_{2}+\mathrm{O}_{3}^{-}=\mathrm{O}_{2}+\mathrm{O}_{2}+\mathrm{OH}^{-}$ \\
\hline 57 & $5.0 \mathrm{E}+08$ & $\mathrm{HO}_{2}+\mathrm{O}_{3}=\mathrm{HO}_{3}+\mathrm{O}_{2}$ \\
\hline 58 & $1.0 \mathrm{E}+02$ & $\mathrm{O}_{2}^{-}+\mathrm{O}_{2}^{-}+\mathrm{H}_{2} \mathrm{O}+\mathrm{H}_{2} \mathrm{O}=\mathrm{H}_{2}+\mathrm{O}_{2}+\mathrm{O}_{2}+\mathrm{OH}^{-}+\mathrm{OH}^{-}$ \\
\hline 59 & $6.0 \mathrm{E}+08$ & $\mathrm{O}_{2}^{-}+\mathrm{O}^{-}+\mathrm{H}_{2} \mathrm{O}=\mathrm{O}_{2}+\mathrm{OH}^{-}+\mathrm{OH}^{-}$ \\
\hline 60 & $1.3 \mathrm{E}-01$ & $\mathrm{O}_{2}^{-}+\mathrm{H}_{2} \mathrm{O}_{2}=\mathrm{OH}+\mathrm{O}_{2}+\mathrm{OH}^{-}$ \\
\hline 61 & $1.3 \mathrm{E}-01$ & $\mathrm{O}_{2}^{-}+\mathrm{HO}_{2}^{-}=\mathrm{O}^{-}+\mathrm{O}_{2}+\mathrm{OH}^{-}$ \\
\hline 62 & $1.0 \mathrm{E}+04$ & $\mathrm{O}_{2}^{-}+\mathrm{O}_{3}^{-}+\mathrm{H}_{2} \mathrm{O}=\mathrm{O}_{2}+\mathrm{O}_{2}+\mathrm{OH}^{-}+\mathrm{OH}^{-}$ \\
\hline 63 & $1.5 \mathrm{E}+09$ & $\mathrm{O}_{2}^{-}+\mathrm{O}_{3}=\mathrm{O}_{3}^{-}+\mathrm{O}_{2}$ \\
\hline 64 & $1.0 \mathrm{E}+09$ & $\mathrm{O}^{-}+\mathrm{O}^{-}+\mathrm{H}_{2} \mathrm{O}=\mathrm{HO}_{2}^{-}+\mathrm{OH}^{-}$ \\
\hline 65 & $3.6 \mathrm{E}+09$ & $\mathrm{O}^{-}+\mathrm{O}_{2}=\mathrm{O}_{3}^{-}$ \\
\hline 66 & $8.0 \mathrm{E}+07$ & $\mathrm{O}^{-}+\mathrm{H}_{2}=\mathrm{H}+\mathrm{OH}^{-}$ \\
\hline 67 & $5.0 \mathrm{E}+08$ & $\mathrm{O}^{-}+\mathrm{H}_{2} \mathrm{O}_{2}=\mathrm{O}_{2}^{-}+\mathrm{H}_{2} \mathrm{O}$ \\
\hline 68 & $4.0 \mathrm{E}+08$ & $\mathrm{O}^{-}+\mathrm{HO}_{2}^{-}=\mathrm{O}_{2}^{-}+\mathrm{OH}^{-}$ \\
\hline 69 & $7.0 \mathrm{E}+08$ & $\mathrm{O}^{-}+\mathrm{O}_{3}^{-}=\mathrm{O}_{2}^{-}+\mathrm{O}_{2}^{-}$ \\
\hline 70 & $5.0 \mathrm{E}+09$ & $\mathrm{O}^{-}+\mathrm{O}_{3}=\mathrm{O}_{2}^{-}+\mathrm{O}_{2}$ \\
\hline 71 & $3.3 \mathrm{E}+03$ & $\mathrm{O}_{3}^{-}=\mathrm{O}_{2}+\mathrm{O}^{-}$ \\
\hline 72 & $9.0 \mathrm{E}+10$ & $\mathrm{O}_{3}^{-}+\mathrm{H}^{+}=\mathrm{O}_{2}+\mathrm{OH}$ \\
\hline 73 & $1.1 \mathrm{E}+05$ & $\mathrm{HO}_{3}=\mathrm{O}_{2}+\mathrm{OH}$ \\
\hline 77 & $1.0 \mathrm{E}+09$ & $\mathrm{O}+\mathrm{O}=\mathrm{O}_{2}$ \\
\hline 78 & $5.0 \mathrm{E}+10$ & $\mathrm{H}^{+}+\mathrm{CO}_{3}^{-2}=\mathrm{HCO}_{3}^{-}$ \\
\hline 79 & $7.0 \mathrm{E}+01$ & $\mathrm{CO}_{2}+\mathrm{H}_{2} \mathrm{O}=\mathrm{H}^{+}+\mathrm{HCO}_{3}^{-}$ \\
\hline 80 & $1.0 \mathrm{E}+10$ & $\mathrm{H}^{+}+\mathrm{HCO}_{3}^{-}=\mathrm{CO}_{2}+\mathrm{H}_{2} \mathrm{O}$ \\
\hline 81 & $2.0 \mathrm{E}+00$ & $\mathrm{HCO}_{3}^{-}=\mathrm{CO}_{3}^{-2}+\mathrm{H}^{+}$ \\
\hline 82 & $7.7 \mathrm{E}+09$ & $\mathrm{CO}_{2}+\mathrm{e}^{-}=\mathrm{CO}_{2}^{-}$ \\
\hline
\end{tabular}




\begin{tabular}{|c|c|c|}
\hline$\#$ & Rate $\left(\mathrm{M}^{-1} \mathrm{~s}^{-1}\right)$ & Reaction \\
\hline 83 & $8.5 \mathrm{E}+06$ & $\mathrm{HCO}_{3}^{-}+\mathrm{OH}=\mathrm{CO}_{3}^{-}+\mathrm{H}_{2} \mathrm{O}$ \\
\hline 84 & $3.9 \mathrm{E}+08$ & $\mathrm{CO}_{3}^{-2}+\mathrm{OH}=\mathrm{CO}_{3}^{-}+\mathrm{OH}^{-}$ \\
\hline 85 & $4.4 \mathrm{E}+04$ & $\mathrm{HCO}_{3}^{-}+\mathrm{H}=\mathrm{H}_{2}+\mathrm{CO}_{3}^{-}$ \\
\hline 86 & $3.9 \mathrm{E}+05$ & $\mathrm{CO}_{3}^{-2}+\mathrm{e}^{-}=\mathrm{CO}_{2}^{-}+\mathrm{OH}^{-}+\mathrm{OH}^{-}-\mathrm{H}_{2} \mathrm{O}$ \\
\hline 87 & $1.4 \mathrm{E}+07$ & $\mathrm{CO}_{3}^{-}+\mathrm{CO}_{3}^{-}=\mathrm{C}_{2} \mathrm{O}_{6}^{-2}$ \\
\hline 88 & $7.00 \mathrm{E}+06$ & $\mathrm{CO}_{3}^{-}+\mathrm{CO}_{3}^{-}=\mathrm{CO}_{2}+\mathrm{CO}_{4}^{-2}$ \\
\hline 89 & $9.8 \mathrm{E}+05$ & $\mathrm{CO}_{3}^{-}+\mathrm{H}_{2} \mathrm{O}_{2}=\mathrm{CO}_{3}^{-2}+\mathrm{O}_{2}^{-}+\mathrm{H}^{+}+\mathrm{H}^{+}$ \\
\hline 90 & $1.0 \mathrm{E}+07$ & $\mathrm{CO}_{3}^{-}+\mathrm{HO}_{2}^{-}=\mathrm{CO}_{3}^{-2}+\mathrm{O}_{2}^{-}+\mathrm{H}^{+}$ \\
\hline 91 & $4.0 \mathrm{E}+08$ & $\mathrm{CO}_{3}^{-}+\mathrm{O}_{2}^{-}=\mathrm{CO}_{3}^{-2}+\mathrm{O}_{2}$ \\
\hline 92 & $3.0 \mathrm{E}+08$ & $\mathrm{CO}_{3}^{-}+\mathrm{CO}_{2}^{-}=\mathrm{CO}_{3}^{-2}+\mathrm{CO}_{2}$ \\
\hline 93 & $1.0 \mathrm{E}+09$ & $\mathrm{CO}_{2}^{-}+\mathrm{e}^{-}=\mathrm{HCO}_{2}^{-}+\mathrm{OH}^{-}-\mathrm{H}_{2} \mathrm{O}$ \\
\hline 94 & $6.5 \mathrm{E}+08$ & $\mathrm{CO}_{2}^{-}+\mathrm{CO}_{2}^{-}=\mathrm{C}_{2} \mathrm{O}_{4}^{-2}$ \\
\hline 95 & $2.0 E+09$ & $\mathrm{CO}_{2}^{-}+\mathrm{O}_{2}=\mathrm{CO}_{2}+\mathrm{O}_{2}^{-}$ \\
\hline 96 & $7.3 E+05$ & $\mathrm{CO}_{2}^{-}+\mathrm{H}_{2} \mathrm{O}_{2}=\mathrm{CO}_{2}+\mathrm{OH}^{-}+\mathrm{OH}$ \\
\hline 97 & $1.0 \mathrm{E}+03$ & $\mathrm{CO}_{2}^{-}+\mathrm{HCO}_{3}^{-}=\mathrm{HCO}_{2}^{-}+\mathrm{CO}_{3}^{-}$ \\
\hline 98 & $1.0 \mathrm{E}+00$ & $\mathrm{C}_{2} \mathrm{O}_{6}^{-2}=\mathrm{C}_{2} \mathrm{O}_{4}^{-2}+\mathrm{O}_{2}$ \\
\hline 99 & $2.0 \mathrm{E}+02$ & $\mathrm{C}_{2} \mathrm{O}_{6}^{-2}=\mathrm{HO}_{2}^{-}+\mathrm{OH}^{-}+\mathrm{CO}_{2}+\mathrm{CO}_{2}-\mathrm{H}_{2} \mathrm{O}$ \\
\hline 100 & $3.0 \mathrm{E}+03$ & $\mathrm{CO}_{3}^{-}+\mathrm{C}_{2} \mathrm{O}_{4}^{-2}=\mathrm{C}_{2} \mathrm{O}_{4}^{-}+\mathrm{CO}_{3}^{2-}$ \\
\hline 102 & 7.7E+06 & $\mathrm{C}_{2} \mathrm{O}_{4}^{-2}+\mathrm{OH}=\mathrm{C}_{2} \mathrm{O}_{4}^{-}+\mathrm{OH}^{-}$ \\
\hline 103 & $4.8 \mathrm{E}+08$ & $\mathrm{C}_{2} \mathrm{O}_{4}^{-}+\mathrm{C}_{2} \mathrm{O}_{4}^{-}=\mathrm{CO}_{2}+\mathrm{CO}_{2}+\mathrm{C}_{2} \mathrm{O}_{4}^{2-}$ \\
\hline 104 & $5 E+09$ & $\mathrm{C}_{2} \mathrm{O}_{4}^{-}+\mathrm{O}_{2}=\mathrm{O}_{2}^{-}+\mathrm{CO}_{2}+\mathrm{CO}_{2}$ \\
\hline 106 & $1.5 \mathrm{E}+05$ & $\mathrm{CO}_{3}^{-}+\mathrm{HCO}_{2}^{-}=\mathrm{HCO}_{3}^{-}+\mathrm{CO}_{2}^{-}$ \\
\hline 107 & $3.2 E+09$ & $\mathrm{HCO}_{2}^{-}+\mathrm{OH}=\mathrm{H}_{2} \mathrm{O}+\mathrm{CO}_{2}^{-}$ \\
\hline 108 & $2.1 \mathrm{E}+08$ & $\mathrm{HCO}_{2}^{-}+\mathrm{H}=\mathrm{H}_{2}+\mathrm{CO}_{2}^{-}$ \\
\hline 109 & $8.0 \mathrm{E}+08$ & $\mathrm{HCO}_{2}^{-}+\mathrm{e}^{-}=\mathrm{H}_{2}+\mathrm{CO}_{2}^{-}-\mathrm{H}^{+}$ \\
\hline 110 & $1.0 \mathrm{E}+09$ & $\mathrm{OH}^{-}+\mathrm{HCO}_{3}^{-}=\mathrm{CO}_{3}^{-2}+\mathrm{H}_{2} \mathrm{O}$ \\
\hline 111 & $3.6 \mathrm{E}+03$ & $\mathrm{CO}_{3}^{-2}+\mathrm{H}_{2} \mathrm{O}=\mathrm{OH}^{-}+\mathrm{HCO}_{3}^{-}$ \\
\hline 112 & $7.0 E+06$ & $\mathrm{CO}_{3}^{-}+\mathrm{CO}_{3}^{-}=\mathrm{CO}_{4}^{-2}+\mathrm{CO}_{2}$ \\
\hline
\end{tabular}




\begin{tabular}{|c|c|c|}
\hline$\#$ & Rate $\left(\mathrm{M}^{-1} \mathrm{~s}^{-1}\right)$ & Reaction \\
\hline 113 & 2.0E-01 & $\mathrm{H}_{2} \mathrm{O}+\mathrm{CO}_{4}^{-2}=\mathrm{HO}_{2}^{-}+\mathrm{CO}_{2}+\mathrm{OH}^{-}$ \\
\hline 114 & $2.25 \mathrm{E}-07$ & $\mathrm{H}_{2} \mathrm{O}_{2}=\mathrm{OH}+\mathrm{OH}$ \\
\hline 115 & $2.50 \mathrm{E}+10$ & $\mathrm{TcO}_{4}^{-}+\mathrm{e}^{-}=\mathrm{TcO}_{4}^{-2}$ \\
\hline 116 & $1.50 \mathrm{E}+05$ & $\mathrm{TcO}_{4}^{-2}+\mathrm{TcO}_{4}^{-2}+\mathrm{H}_{2} \mathrm{O}=\mathrm{TcO}_{4}^{-}+\mathrm{TcO}_{3}^{-}+\mathrm{OH}^{-}+\mathrm{OH}^{-}$ \\
\hline 117 & $2.40 \mathrm{E}+03$ & $\mathrm{TcO}_{3}^{-}+\mathrm{TcO}_{3}^{-}=\mathrm{TcO}_{4}^{-2}+\mathrm{TcO}_{2}$ \\
\hline 119 & $2.90 \mathrm{E}+07$ & $\mathrm{TcO}_{4}^{-}+\mathrm{NO}_{3}^{-2}=\mathrm{TcO}_{4}^{-2}+\mathrm{NO}_{3}^{-}$ \\
\hline 120 & $2.00 E+09$ & $\mathrm{TcO}_{4}^{-2}+\mathrm{OH}=\mathrm{TcO}_{4}^{-}+\mathrm{OH}^{-}$ \\
\hline 121 & $2.00 \mathrm{E}+08$ & $\mathrm{TcO}_{4}{ }^{-2}+\mathrm{CO}_{3}^{-}=\mathrm{TcO}_{4}^{-}+\mathrm{CO}_{3}{ }^{2-}$ \\
\hline 122 & $9.70 E+09$ & $\mathrm{NO}_{3}^{-}+\mathrm{e}^{-}=\mathrm{NO}_{3}^{-2}$ \\
\hline 123 & $1.00 \mathrm{E}+03$ & $\mathrm{NO}_{3}^{-2}+\mathrm{H}_{2} \mathrm{O}=\mathrm{NO}_{2}+\mathrm{OH}^{-}+\mathrm{OH}^{-}$ \\
\hline 124 & $6.00 \mathrm{E}+07$ & $\mathrm{NO}_{2}+\mathrm{NO}_{2}+\mathrm{H}_{2} \mathrm{O}=\mathrm{NO}_{3}^{-}+\mathrm{NO}_{2}^{-}+\mathrm{H}^{+}+\mathrm{H}^{+}$ \\
\hline 125 & $1.80 \mathrm{E}+07$ & $\mathrm{NO}_{2}^{-}+\mathrm{O}^{-}=\mathrm{NO}_{3}^{-2}$ \\
\hline
\end{tabular}


Appendix C: Calculated Rates of Pertechnetate Reduction in Hanford Tanks

\begin{tabular}{|c|c|c|}
\hline Tank & Dose(rad/s) & $k \_r e d\left(s^{\wedge}-1\right)$ \\
\hline 241-AN-101 & 0.024664587 & $1.84319 \mathrm{E}-08$ \\
\hline 241-AN-102 & 0.220742359 & $2.02342 \mathrm{E}-07$ \\
\hline 241-AN-103 & 0.277867761 & 2.92651E-07 \\
\hline 241-AN-104 & 0.216039747 & 2.27291E-07 \\
\hline 241-AN-105 & 0.128684161 & 1.3516E-07 \\
\hline 241-AN-106 & 0.00456311 & 4.17901E-09 \\
\hline 241-AN-107 & 0.19510172 & $1.84504 \mathrm{E}-07$ \\
\hline 241-AP-101 & 0.07519206 & $7.75468 \mathrm{E}-08$ \\
\hline 241-AP-102 & 0.106002429 & $1.10934 \mathrm{E}-07$ \\
\hline 241-AP-103 & 0.102078074 & $1.03621 \mathrm{E}-07$ \\
\hline 241-AP-104 & 0.023645441 & $2.34883 \mathrm{E}-08$ \\
\hline 241-AP-105 & 0.15773929 & $1.63776 \mathrm{E}-07$ \\
\hline 241-AP-106 & 0.077989809 & 7.42478E-08 \\
\hline 241-AP-107 & 0.154611084 & 1.49261E-07 \\
\hline 241-AP-108 & 0.091860377 & $9.54424 \mathrm{E}-08$ \\
\hline 241-AW-101 & 0.166226204 & $1.75073 \mathrm{E}-07$ \\
\hline 241-AW-102 & 0.115771694 & 1.11925E-07 \\
\hline 241-AW-103 & 0.050143366 & $4.94612 E-08$ \\
\hline 241-AW-104 & 0.106952599 & $1.1144 \mathrm{E}-07$ \\
\hline 241-AW-105 & 0.004733314 & 3.73552E-09 \\
\hline 241-AW-106 & 0.199571739 & 1.98619E-07 \\
\hline 241-AY-101 & 0.008125141 & 6.74601E-09 \\
\hline 241-AY-102 & 0.068109637 & 7.02045E-08 \\
\hline 241-AZ-101 & 0.707619443 & 6.9115E-07 \\
\hline 241-AZ-102 & 0.185717595 & $1.84003 E-07$ \\
\hline
\end{tabular}

C.1 


\begin{tabular}{|c|c|c|}
\hline Tank & Dose(rad/s) & $k$ red $\left(s^{n}-1\right)$ \\
\hline 241-SY-101 & 0.011202388 & $1.09795 \mathrm{E}-08$ \\
\hline 241-SY-102 & 0.011884173 & $1.15743 \mathrm{E}-08$ \\
\hline 241-SY-103 & 0.190634841 & 1.9997E-07 \\
\hline 241-A-101 & 0.15338168 & 1.61197E-07 \\
\hline 241-A-102 & 0.218853291 & $2.27877 \mathrm{E}-07$ \\
\hline 241-A-103 & 0.119865044 & $1.25815 \mathrm{E}-07$ \\
\hline 241-AX-101 & 0.150500042 & $1.58225 \mathrm{E}-07$ \\
\hline 241-AX-103 & 0.156909264 & 1.64689E-07 \\
\hline 241-B-101 & 0.010443918 & $1.09349 E-08$ \\
\hline 241-B-102 & 0.005211512 & $3.73717 \mathrm{E}-09$ \\
\hline 241-B-103 & 0.005211508 & 3.97706E-09 \\
\hline 241-B-104 & 0.005211507 & $2.96388 \mathrm{E}-09$ \\
\hline 241-B-105 & 0.005211524 & 4.61967E-09 \\
\hline 241-B-106 & 0.005211512 & 2.96339E-09 \\
\hline 241-B-107 & 0.007775588 & 4.41798E-09 \\
\hline 241-B-108 & 0.005727425 & 5.97617E-09 \\
\hline 241-B-109 & 0.005211503 & 3.99886E-09 \\
\hline 241-B-110 & 0.007556379 & 7.54243E-09 \\
\hline 241-B-111 & 0.007556379 & 4.28988E-09 \\
\hline 241-B-112 & 0.068683197 & $7.05746 \mathrm{E}-08$ \\
\hline 241-B-203 & 9.09467E-08 & $5.20108 \mathrm{E}-14$ \\
\hline 241-B-204 & 4.04236E-08 & $3.86256 \mathrm{E}-14$ \\
\hline 241-BX-103 & 0.000587396 & 3.37173E-10 \\
\hline 241-BX-104 & 0.055422933 & $4.58573 \mathrm{E}-08$ \\
\hline 241-BX-105 & 0.056962404 & $5.97314 \mathrm{E}-08$ \\
\hline 241-BX-106 & 0.06868314 & $4.20748 \mathrm{E}-08$ \\
\hline 241-BX-110 & 0.057213071 & $5.87945 \mathrm{E}-08$ \\
\hline
\end{tabular}



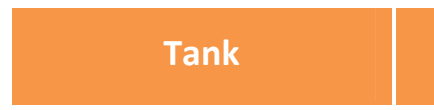

\section{Dose $(\mathrm{rad} / \mathrm{s})$}

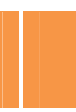

k_red $\left(s^{\wedge}-1\right)$

\begin{tabular}{|c|}
\hline $241-B X-111$ \\
\hline $241-B X-112$ \\
\hline $241-B Y-101$ \\
\hline
\end{tabular}

\begin{tabular}{|c|c|}
\hline 0.059891811 & $6.30025 \mathrm{E}-08$ \\
\hline 0.000825033 & $8.64988 \mathrm{E}-10$ \\
\hline 0.068682971 & $7.19979 \mathrm{E}-08$ \\
\hline
\end{tabular}

\begin{tabular}{|l|}
\hline $241-B Y-102$ \\
\hline $241-B Y-103$ \\
\hline $241-B Y-104$ \\
\hline
\end{tabular}

\begin{tabular}{|c|c|}
\hline 0.060853525 & $6.40135 \mathrm{E}-08$ \\
\hline 0.04238183 & $4.41086 \mathrm{E}-08$ \\
\hline
\end{tabular}

\begin{tabular}{|l|}
\hline 241-BY-104 \\
\hline $241-B Y-105$ \\
\hline $241-B Y-106$
\end{tabular}

\begin{tabular}{|l|l|}
\hline 0.065317666 & $6.73129 \mathrm{E}-08$ \\
\hline 0.082738517 & $8.62594 \mathrm{E}-08$ \\
\hline
\end{tabular}

\begin{tabular}{|l|}
\hline $241-B Y-106$ \\
\hline $241-B Y-107$ \\
\hline $241-B Y-108$ \\
\hline $241-B Y-109$ \\
\hline
\end{tabular}

0.076333568
$8.0119 E-08$

\begin{tabular}{|l|l|}
\hline 0.06353189 & $6.68728 \mathrm{E}-08$ \\
\hline
\end{tabular}

\begin{tabular}{|c|}
\hline $241-B Y-109$ \\
\hline $241-B Y-110$ \\
\hline $241-B Y-111$ \\
\hline $241-B Y-112$ \\
\hline $241-C-103$ \\
\hline
\end{tabular}

\begin{tabular}{|c|c|}
\hline 0.075826291 & $7.93353 \mathrm{E}-08$ \\
\hline 0.059685615 & $6.26572 \mathrm{E}-08$ \\
\hline 0.073284823 & $7.6647 \mathrm{E}-08$ \\
\hline 0.055564755 & $5.82631 \mathrm{E}-08$ \\
\hline
\end{tabular}

241-C-103

0.06408163
$6.74928 \mathrm{E}-08$

\begin{tabular}{|c|c|}
\hline $8.97665 \mathrm{E}-05$ & $9.46387 \mathrm{E}-11$ \\
\hline 0.000218081 & $2.29918 \mathrm{E}-10$ \\
\hline 0 & 0 \\
\hline
\end{tabular}

\begin{tabular}{|l|}
\hline $241-C-106$ \\
\hline $241-C-201$ \\
\hline $241-C-202$ \\
\hline $241-C-203$ \\
\hline
\end{tabular}

\begin{tabular}{|c|}
\hline $241-C-202$ \\
\hline $241-C-203$ \\
\hline $241-C-204$
\end{tabular}

241-C-204

\begin{tabular}{|c|c|}
\hline 0 & 0 \\
\hline 0 & 0 \\
\hline 0 & 0 \\
\hline 0.11983556 & $1.25581 \mathrm{E}-07$ \\
\hline 0 & 0 \\
\hline 0.142489122 & $1.4924 \mathrm{E}-07$ \\
\hline 0.027746309 & $2.8333 \mathrm{E}-08$ \\
\hline 0.156909523 & $1.64689 \mathrm{E}-07$ \\
\hline 0.102045631 & $1.07138 \mathrm{E}-07$ \\
\hline 0.156909554 & $1.64689 \mathrm{E}-07$ \\
\hline
\end{tabular}




\begin{tabular}{|c|c|c|}
\hline Tank & Dose(rad/s) & $k$ red $\left(s^{n}-1\right)$ \\
\hline 241-S-109 & 0.125349042 & $1.31898 \mathrm{E}-07$ \\
\hline $241-S-110$ & 0.154085006 & 1.61761E-07 \\
\hline $241-S-111$ & 0.131992138 & $1.38246 \mathrm{E}-07$ \\
\hline 241-S-112 & 0 & 0 \\
\hline 241-SX-101 & 0.155719384 & $1.63645 \mathrm{E}-07$ \\
\hline 241-SX-102 & 0.171632015 & $1.80606 \mathrm{E}-07$ \\
\hline 241-SX-103 & 0.17828126 & $1.87545 \mathrm{E}-07$ \\
\hline 241-SX-104 & 0.100882207 & $1.0528 \mathrm{E}-07$ \\
\hline 241-SX-105 & 0.149310281 & $1.56811 \mathrm{E}-07$ \\
\hline 241-SX-106 & 0.146554084 & $1.53482 \mathrm{E}-07$ \\
\hline 241-SX-114 & 0.124066594 & 1.30764E-07 \\
\hline 241-T-101 & 0.15690922 & 1.64689E-07 \\
\hline 241-T-102 & 0.023249854 & $1.34184 \mathrm{E}-08$ \\
\hline 241-T-103 & 0.007556369 & 4.94676E-09 \\
\hline 241-T-108 & 0.005211511 & 4.05398E-09 \\
\hline 241-T-109 & 0.005211528 & $2.96451 \mathrm{E}-09$ \\
\hline 241-T-110 & $1.56168 \mathrm{E}-06$ & 8.86549E-13 \\
\hline 241-T-112 & 0.004141947 & 4.32869E-09 \\
\hline 241-T-201 & 4.17775E-08 & $3.42503 \mathrm{E}-14$ \\
\hline 241-TX-101 & 0.156909426 & $1.64689 \mathrm{E}-07$ \\
\hline 241-TX-102 & 0.156909162 & 1.64689E-07 \\
\hline 241-TX-103 & 0.151555244 & $1.59038 \mathrm{E}-07$ \\
\hline 241-TX-104 & 0.14718122 & $1.52072 \mathrm{E}-07$ \\
\hline 241-TX-105 & 0.156909585 & 1.6469E-07 \\
\hline 241-TX-106 & 0.156909554 & 1.64689E-07 \\
\hline 241-TX-107 & 0.148067073 & $1.55363 \mathrm{E}-07$ \\
\hline 241-TX-108 & 0.156909827 & 1.6469E-07 \\
\hline
\end{tabular}

C. 4 

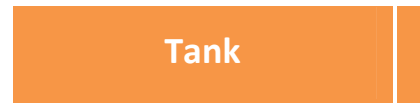

\section{Dose(rad/s)}

(1)

\section{1-TX-112}

\begin{tabular}{|c|}
\hline $241-T X-112$ \\
\hline $241-T X-114$ \\
\hline
\end{tabular}

241-TX-114

241-TX-115

241-TX-116

241-TX-117

241-TX-118

241-TY-101

\section{1-TY-102}

\section{1-TY-103}

\section{1-TY-104}

\begin{tabular}{|l|}
\hline $241-\mathrm{U}-102$ \\
\hline $241-\mathrm{U}-103$
\end{tabular}

\begin{tabular}{|l|}
\hline $241-U-103$ \\
\hline $241-U-105$ \\
\hline $241-U-106$ \\
\hline
\end{tabular}

\begin{tabular}{|l|}
\hline $241-U-106$ \\
\hline $241-U-107$ \\
\hline $241-U-108$ \\
\hline
\end{tabular}

241-U-108

241-U-109

\begin{tabular}{|l|}
\hline $241-U-109$ \\
\hline $241-U-111$ \\
\hline $241-U-201$
\end{tabular}

241-U-201

241-U-202

241-U-203

241-U-204

0.15

0.15

(1)

0

(1)

0.15

0.

0.

0.16

0.157

(1)

0.14

0.15

0.01

0.156909693

0.005078383

0.202043349

0.201638887

0.166910507

0.157520297

0.150386216

0.14340249

0.152608652

0.011962468

0.008607682

0.002994682

\begin{tabular}{|l|l|}
\hline 0.156909345 & 1.6 \\
\hline 0.062610757 & 6.4 \\
\hline
\end{tabular}

\begin{tabular}{|l|l|}
\hline 0.009060537 & $7.09989 \mathrm{E}-09$ \\
\hline 0.005211532 & $2.95944 \mathrm{E}-09$ \\
\hline 0.156909537 & $1.64689 \mathrm{E}-07$ \\
\hline
\end{tabular}

.

\begin{tabular}{|c|c|}
\hline 0.005211501 \\
\hline 0.087080775 \\
\hline
\end{tabular}

2.11494E-07

2.11359E-07

1.57577E-07

0.15031158
$1.57652 \mathrm{E}-07$

$1.50425 \mathrm{E}-07$

1.59609E-07

1.19756E-08

8.59843E-09

7.66973E-09

2.10627E-09 


\section{Distribution}

No. of

\section{Copies}

\# WRPS

Richland, WA 99352

Leo Thompson

Dave Swanberg

Rebecca Robbins

James Duncan

\# ORP

Richland, WA 99352

Tom Fletcher

Billie Mauss

Steve Pfaff

\# SNRL

Aiken, SC 29808

Daniel McCabe

daniel.mccabe@srnl.doe.gov
No. of

\section{$\underline{\text { Copies }}$}

PDF

PDF

PDF

PDF

PDF

PDF

PDF

PDF

\section{\# Local Distribution}

Pacific Northwest National Laboratory

Brian Rapko

PDF

Reid Peterson

PDF

Janet Bryant

PDF

Sam Bryan

PDF

Tatiana Levitskaia

PDF

Sergei Sinkov

PDF

Joy Houchin

PDF

Matt Edwards

PDF

James Peterson

PDF

Dev Chatterjee

PDF 


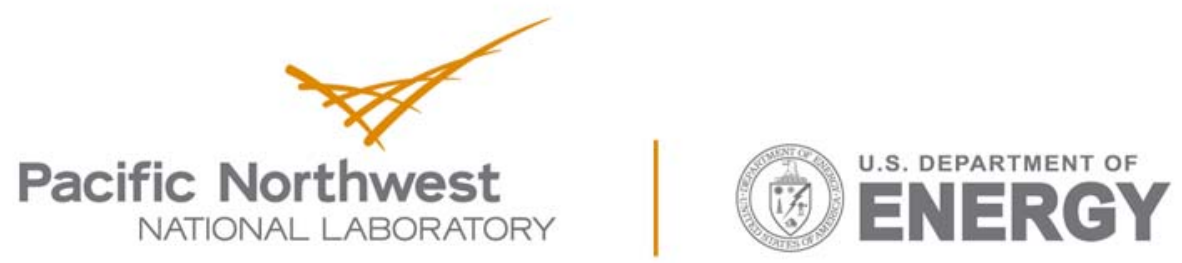

Proudly Operated by Battelle Since 1965

902 Battelle Boulevard

P.O. Box 999

Richland, WA 99352

1-888-375-PNNL (7665)

www.pnnl.gov 